\title{
Biosynthesis, occurrence and characterization of gla- containing proteins with a potential importance for cardiovascular diseases
}

Citation for published version (APA):

de Haarlem, L. E. M. (1989). Biosynthesis, occurrence and characterization of gla-containing proteins with a potential importance for cardiovascular diseases. [Doctoral Thesis, Maastricht University]. Datawyse / Universitaire Pers Maastricht. https://doi.org/10.26481/dis.19890616ld

Document status and date:

Published: 01/01/1989

DOI:

10.26481/dis.19890616ld

Document Version:

Publisher's PDF, also known as Version of record

Please check the document version of this publication:

- A submitted manuscript is the version of the article upon submission and before peer-review. There can be important differences between the submitted version and the official published version of record.

People interested in the research are advised to contact the author for the final version of the publication, or visit the DOI to the publisher's website.

- The final author version and the galley proof are versions of the publication after peer review.

- The final published version features the final layout of the paper including the volume, issue and page numbers.

Link to publication

\footnotetext{
General rights rights.

- You may freely distribute the URL identifying the publication in the public portal. please follow below link for the End User Agreement:

www.umlib.nl/taverne-license

Take down policy

If you believe that this document breaches copyright please contact us at:

repository@maastrichtuniversity.nl

providing details and we will investigate your claim.
}

Copyright and moral rights for the publications made accessible in the public portal are retained by the authors and/or other copyright owners and it is a condition of accessing publications that users recognise and abide by the legal requirements associated with these

- Users may download and print one copy of any publication from the public portal for the purpose of private study or research.

- You may not further distribute the material or use it for any profit-making activity or commercial gain

If the publication is distributed under the terms of Article 25fa of the Dutch Copyright Act, indicated by the "Taverne" license above, 
BIOSYNTHESIS, OCCURRENCE AND CHARACTERIZATION OF GLA-CONTAINING PROTEINS WITH A POTENTIAL IMPORTANCE FOR CARDIOVASCULAR DISEASES 


\section{CIP-DATA KONINKLIJKE BIBLIOTHEEK, DEN HAAG}

Haarlem, Leonardus Johan Marie van

Biosynthesis, occurrence and characterization of Gla-containing proteins with a potential importance for cardiovascular diseases /Leonardus Johan Marie van Haarlem. - Maastricht: Universitaire Pers Maastricht. - I11

Thesis Maastricht. - with index, ref.

ISBN 90-5278-001-3

SISO 605.12 UDC 616.12/.14:577.1 (043.3) NUGI 743

Subject headings: Gla-containing proteins/vitamin K-dependent carboxylase/ cardiovascular diseases

Omslag: Hennie Bastiaens

Druk: Wibro Dissertatiedrukkerij, Helmond 


\section{BIOSYNTHESIS, OCCURRENCE AND CHARACTERIZATION OF GLA-CONTAINING PROTEINS WITH A POTENTIAL IMPORTANCE FOR CARDIOVASCULAR DISEASES}

\section{PROEFSCHRIFT}

ter verkrijging van de graad van doctor aan de Rijksuniversiteit Limburg te Maastricht, op gezag van de Rector Magnificus, Prof. Dr. F.I.M. Bonke, volgens het besluit van het College van Dekanen, in het openbaar te verdedigen op vrijdag, 16 juni 1989 om 16.00 uur

door

Leonardus Johan Marie van Haarlem

geboren te Maastricht in 1960 


\section{Promotor:}

Prof. Dr. H.C. Hemker

\section{Co-promotor:}

Dr. C. Vermeer

\section{Beoordelingscommissie:}

Prof. Dr. F.T. Bosman, Rijksuniversiteit Limburg, Maastricht (voorzitter) Prof. Dr. P.J. Brombacher, Rijksuniversiteit Limburg, Maastricht Dr. E.J.P. Brommer, Gaubius Instituut TNO, Leiden Prof. Dr. F. ten Hoor, Rijksuniversiteit Limburg, Maastricht Dr. H.H.W. Thijssen, Rijksuniversiteit Limburg, Maastricht

The work presented in this thesis has been done in close collaboration with Marjo Knapen, Peet van de Loo, Berry Soute, Magda Ulrich and Cees Vermeer, and was financially supported by grant 900-526-052 from the Division for Health Research TNO and by grant $86.028 \mathrm{~h}$ from the Netherlands Heart Foundation.

Financial support by the Netherlands Heart Foundation and the Scholten-Cordes Foundation for the publication of this thesis is gratefully acknowledged. 
There's so many different worlds So many different suns And we have just one world But we live in different ones

\section{DIRE STRAITS}

Aan mijn moeder Ter herinnering aan mijn vader Aan Lucienne 



\section{CONTENTS}

List of abbreviations

Chapter 1 Introduction

Chapter 2 Some properties of the hepatic and non-hepatic vitamin Kdependent enzyme reactions

A. Substrate recognition by vitamin K-dependent carboxylase.

[Thrombos. Haemost. 57: 17-19, 1987]

B. Isolation and partial characterization of a vitamin $\mathrm{K}$ dependent carboxylase from bovine aortae.

[Biochem. J. 245: 251-255, 1987]

C. Vitamin K-dependent carboxylase:

possible role for thioredoxin in the reduction of vitamin $\mathrm{K}$ metabolites in liver.

[FEBS Lett. 222: 353-357, 1987]

Chapter 3 Studies on osteocalcin: a model protein for the development of various assays

A. The effect of Gla-containing proteins on the precipitation of insoluble salts.

[Biochem. Biophys. Res. Commun. 142: 113-119, 1987]

B. The quantification of gammacarboxyglutamic acid residues in plasma-osteocalcin.

[Calcif. Tissue Int. 43: 184-188, 1988]

C. Circulating osteocalcin during oral anticoagulant treatment.

[Thrombos. Haemost. 60: 79-82, 1988] 
Chapter 4 Plaque Gla-protein, a unique Gla-containing protein from calcified human atherosclerotic plaques A. Characterization of Gla-containing proteins from
calcified human atherosclerotic plaques.
[in: Current Advances in Vitamin K Research (Suttie,
J.W., ed.) pp. 287-292, 1988]

B. Purification and partial characterization of a hitherto unidentified Gla-containing protein from calcified human atherosclerotic plaques. [submitted]

C. An ELISA for Plaque Gla-protein (PGP) and its detection in plasma. [submitted]

Chapter 5 Summary and General Discussion 129

Samenvatting $\quad 133$

Dankwoord 137

$\begin{array}{lr}\text { Curriculum Vitae } & 139\end{array}$ 


\section{LIST OF ABBREVIATIONS}

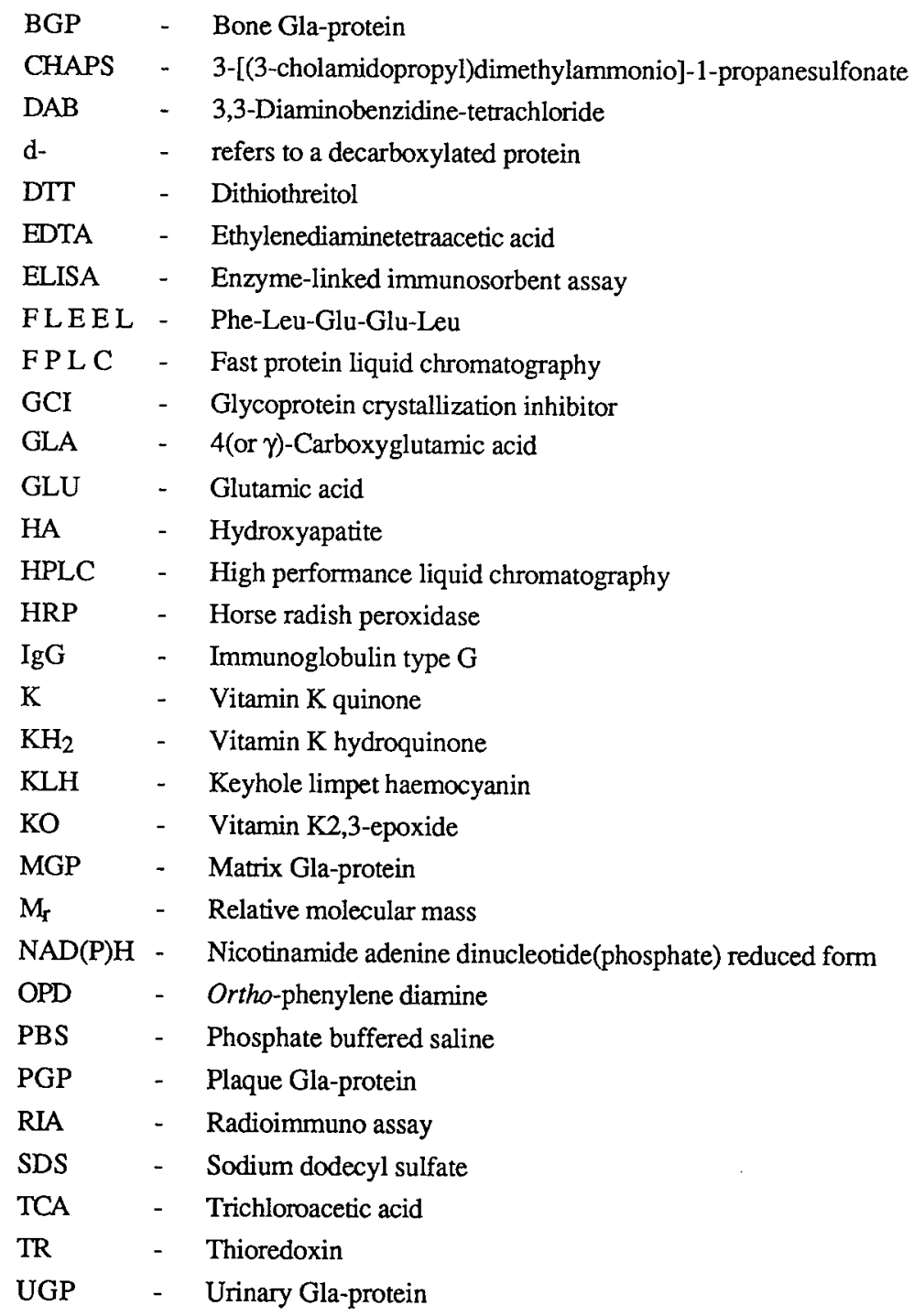





\section{CHAPTER I}

\section{INTRODUCTION}

\section{VITAMIN K AND VITAMIN K ANTAGONISTS}

Vitamin K was discovered by Henrik Dam in 1935 (1). While studying the effects of a cholesterol-depleted diet on chickens, he observed that after some weeks the animals developed hemorrhages. Blood, taken from the animals exhibited a prolonged coagulation time. The observed anti-hemostatic effect could not be counteracted by the addition of purified cholesterol to the food, but appeared to be related to the deficiency of a fat-soluble vitamin. This vitamin was called Koagulations-vitamin (coagulation vitamin) or vitamin $\mathrm{K}$.

It appeared that the bleeding symptoms related to the vitamin $\mathrm{K}$ deficiency were similar to those described for a hemorrhagic disease in cattle (2). The use of improperly cured sweet clover hay as food for the animals turned out to be the prime cause of the disease. The active compound in the clover was identified as 3,3'-methylene-bis-(4-hydroxycoumarin)(dicoumarol) (3), a drug which is chemically bound (and thus inactive) in the fresh plants, but which may be set free during storage of the hay. Further research showed that dicoumarol and some of its derivatives function as antagonists of vitamin $\mathrm{K}$ action. Their anticoagulant potency makes them useful, either for therapeutical purposes during thrombotic episodes or as rodenticides (rat poison) (4). It has been thought for many years that vitamin $\mathrm{K}$ was exclusively required for the proper synthesis of four blood coagulation factors: prothrombin and the factors VII, IX and X. During the last decade, however, additional members of the family of the "vitamin K-dependent proteins" have been discovered, 
including the coagulation inhibiting proteins $\mathrm{C}$ and $\mathrm{S}$ and a number of proteins not related to blood coagulation $(5,6)$.

\section{SYNTHESIS AND FUNCTION OF GLA-CONTAINING PROTEINS}

Vitamin $\mathrm{K}$ is involved in the post-translational modification of proteins. The vitamin $\mathrm{K}$-dependent step in protein biosynthesis is the carboxylation of a number of discrete glutamic acid (Glu) residues into 4-carboxyglutamic acid or gamma-carboxyglutamic acid (Gla) (7-9). The structures of these amino acids are depicted in fig. 1.

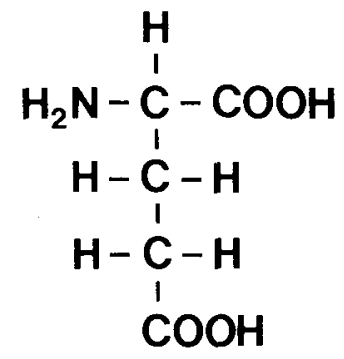

Glu

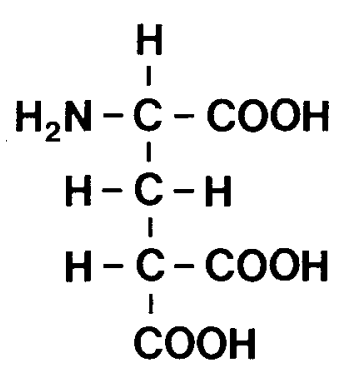

Gla

Fig. 1. Structures of glutamic acid (Glu) and 4-carboxyglutamic acid (Gla).

The only known function of protein-bound Gla-residues is the binding of divalent metal ions. The vitamin $\mathrm{K}$-dependent coagulation factors are able to bind metal ions by high-affinity and low-affinity binding sites, both containing Gla. Occupation of these sites by a variety of metal ions is associated with a conformational transition in the protein (10-14).

During oral anticoagulant therapy the synthesis of Gla-containing proteins is inhibited, leading to the production of inactive coagulation factors (15). As early as in 1963 it was suggested by Hemker et al. that blood plasma from anticoagulated patients contained abnormal coagulation factors (16). However, it lasted until 1974 before the nature of this abnormality could be elucidated. It was reported independently by the groups of Stenflo (7), Nelsestuen (8) and Magnusson (17), that the calcium-binding sites in normal prothrombin were Gla-residues, whereas in abnormal prothrombin these residues were noncarboxylated Glu-residues. 
All vitamin K-dependent proteins identified up to now form part of the family of secretory proteins. Once the maturation of these proteins has been completed, the proteins are excreted into the extracellular fluid or to the outer cellular membrane. Some details about the selection and excretion process of these proteins have become clear by the work of Walter and Blobel (18) and that of Meyer et al. (19). The groups of MacGillivray, Davie and Brownlee have investigated in particular the molecular biology of the Gla-containing coagulation factors (20-22). The secretory proteins contain a hydrophobic leader sequence, consisting of a presegment and a prosegment at the aminoterminal side of the growing peptide chain. The signal sequence is recognized by the signal recognition particle (SRP) which occurs in the cytoplasm. The binding of SRP to the signal sequence results in an immediate stop of protein synthesis. A second protein involved in the process of protein secretion is located on the rough endoplasmic reticulum (RER). The binding of this "docking" protein to the inactivated ribosomal complex results in a reinitiation of protein synthesis. The hydrophobic signal sequence then penetrates into the RER, thus facilitating the transport of the growing protein through the phospholipid membrane into the luminal side of the endoplasmic tubuli. This is the place where the enzymes required for the post-translational modifications are located. More than 100 of these modifications are presently known and they include glycosylation, hydroxylation, the limited proteolytic degradation of the signal sequence and vitamin K-dependent carboxylation. Obviously not all secretory proteins undergo all possible modifications. Moreover, the way in which post-translational enzyme systems can discriminate between the different proteins is still a matter of investigation.

\section{VITAMIN K-DEPENDENT CARBOXYLASE}

Vitamin K-dependent carboxylase activity has been demonstrated first in a crude rat liver microsomal preparation (23). Esmon et al. demonstrated that the hepatic post-mitochondrial supernatants from vitamin $\mathrm{K}$-deficient rats were able to incorporate ${ }^{14} \mathrm{CO}_{2}$ into an endogenous substrate. $\mathrm{NaH}^{14} \mathrm{CO}_{3}$ could be used as a $\mathrm{CO}_{2}$ donor and the incorporation was dependent on the addition of vitamin $\mathrm{K}$. It has been reported that endogenous precursors or decarboxylated plasma prothrombin can be carboxylated (24). The latter observation, however, has not been confirmed by others (25) probably because of the relatively high $K_{m}$ of carboxylase for descarboxyprothrombin (the excreted form of non-carboxylated prothrombin). The vitamin K-dependent carboxylation reaction has been studied most extensively in liver microsomal preparations 
obtained from vitamin K-deficient or warfarin-treated rats and from normal and warfarin-treated cows $(26,27)$. The carboxylase activity appeared to be associated almost exclusively with the luminal side of the rough microsomal membrane. The carboxylase activity can be extracted from the membrane with the aid of detergents such as Lubrol, Triton X-100 and 3-[(3-cholamidopropyl)dimethyl-ammonio]-1-propane sulfonate (CHAPS). When the synthesis of Gla-containing proteins is blocked in vivo by the administration of vitamin $\mathrm{K}$ antagonists, precursors of the Gla-containing proteins accumulate in the RER (9) and when the blockade is prolonged, the non-carboxylated proteins may be excreted into the extracellular fluid. In their excreted form these proteins are designated as descarboxy proteins. The activity of the carboxylating enzyme has been measured in the liver of a number of species, including man $(5,28,29)$. However, vitamin $\mathrm{K}$ was demonstrated to be present not only in liver, but also in many other tissues (30). Vitamin K-dependent carboxylase activity has been demonstrated in microsomal preparations from kidney (31), spleen $(6,32)$, testis $(6)$, lung $(6,32,33)$, pancreas $(6,34)$, placenta $(6,35)$, vessel wall (6), and various isolated human tumors (36). Vitamin K-dependent carboxylase was also present in a wide variety of cultured cells (35,37-39), such as osteoblasts, hepatocytes, endothelial cells and various cultured tumor cells.

\section{THE VITAMIN K CYCLE}

In the liver three major forms of vitamin $\mathrm{K}$ have been identified. Vitamin $\mathrm{K}$ quinone $(\mathrm{K})$, vitamin $\mathrm{K}$ hydroquinone $\left(\mathrm{KH}_{2}\right)$ and vitamin $\mathrm{K}$ 2,3-epoxide (KO). Calculations based on the daily requirement for vitamin $\mathrm{K}$ relative to the formation of $\mathrm{Gla}$, as measured by its excretion, show that each molecule of the vitamin must be recycled several thousand times before it is metabolized further and excreted (40). Therefore, it has been proposed that the three forms of vitamin $\mathrm{K}$ are interconverted into each other as shown in fig. 2 (40,41). Enzymes are required for each step and they will be discussed consecutively.

Step 1: The conversion of $\mathrm{KH}_{2}$ to $\mathrm{KO}$. The microsomal enzyme system involved in this conversion was called "vitamin $\mathrm{K}$ epoxidase" (42). This enzyme may be linked to or identical with the carboxylase. This hypothesis is supported by the observation that increasing the concentration of a Glu-containing peptide substrate for carboxylase results not only in an increase in the number of carboxylation events but also leads to an increase in epoxidase activity (43). It is generally accepted now that the oxidation of $\mathrm{KH}_{2}$ provides the energy required for carboxylation of glutamic acid residues (9). 


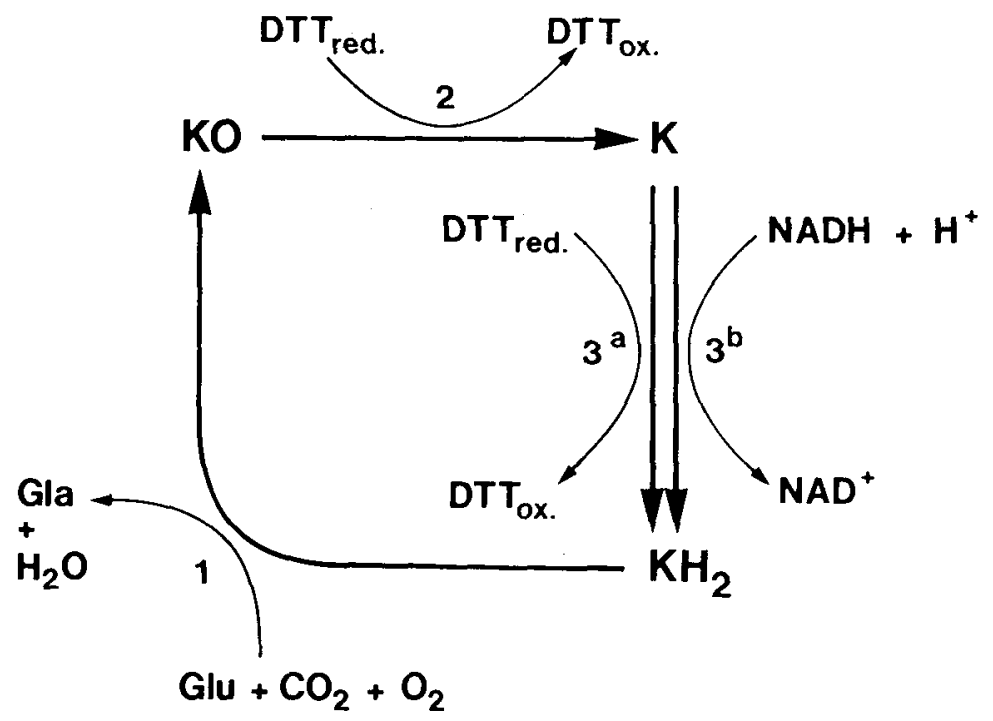

Fig. 2. The vitamin $K$ cycle; for abbreviations see text.

Step 2: The reduction of $\mathrm{KO}$ to $\mathrm{K}$. The enzyme involved in this step is $\mathrm{KO}$ reductase. Some of the properties of this enzyme have been described by Whitlon et al. (44). Matschiner and collegues demonstrated that $\mathrm{KO}$ reductase is extremely sensitive to coumarin anticoagulants (45). The hypothesis that KO reductase is the physiological site of action of these drugs is also supported by the observation that in warfarin-resistant rats $\mathrm{KO}$ reductase has undergone a mutation by which it has become less sensitive to warfarin. In vitro the reducing equivalents required for $\mathrm{KO}$ reduction are provided by dithiols such as dithiotreitol (DTT), but their physiological counterpart has not yet been discovered.

Step 3: The reduction of $\mathrm{K}$ to $\mathrm{KH}_{2}$. At least two enzymes are known to catalyze this step, one driven by DTT and the other(s) by NAD(P)H. Wallin et al. purified the $\mathrm{NAD}(\mathrm{P}) \mathrm{H}$-dependent DT-diaphorase from rat liver (46). It was found that DT-diaphorase is present in both, cytosol and microsomes. The DTT-dependent $\mathrm{K}$ reductase occurs exclusively as a membrane-bound activity. At present it is not clear whether the DTT-dependent $\mathrm{KO}$ and $\mathrm{K}$ reductase activities are catalyzed by the same enzyme or by two different ones $(47,48)$. Similar to KO reductase the DTT-dependent K reductase is strongly inhibited by coumarin derivatives (49). On the other hand, the NADH-dependent enzyme system is relatively insensitive to these drugs $(50,51)$. The coumarin 
derivatives do not affect carboxylase in a direct way, but they induce a scarcity of $\mathrm{KH}_{2}$ and the rate of carboxylation is slowed down by a lack of coenzyme $(47,49,52)$. However, it is well known that in vivo oral anticoagulant treatment can be counteracted efficiently by giving the patient extra vitamin $\mathrm{K}$. It is assumed that under normal conditions the coumarin-sensitive DTT-dependent reductases play a dominant role in the generation of $\mathrm{KH}_{2}$. Only if high amounts of $\mathrm{K}$ are administered to the patient, also the NADH-dependent reductase comes into operation. Since the latter is insensitive to vitamin $\mathrm{K}$ antagonists, the effect of coumarin-like drugs can efficiently be counteracted in vivo by high doses of vitamin $\mathrm{K}$.

\section{SUBSTRATE SPECIFICITY}

On comparing the amino acid sequences of the plasma Gla-proteins, it was impossible to demonstrate a unique sequence that might act as a recognition site for carboxylase (53). In a first approach to study the enzyme-substrate interaction by the vitamin $\mathrm{K}$-dependent carboxylase, a group of exogenous substrates has been synthesized $(54,55)$. These low molecular weight substrates resemble a short Gla-containing amino acid sequence in one of the coagulation factors. For example, Phe-Leu-Glu-Glu-Val (sequence homology with bovine prothrombin and factor $\mathrm{X}$ ) (56), Phe-Leu-Glu-Glu-Leu (sequence homology with bovine factor VII and protein C) (57), and Phe-Leu-Glu-Glu-Ile (sequence homology with rat prothrombin) (58). Although several synthetic peptides may be used as carboxylatable substrates, their $K_{m}$ is invariably high (a few $\mathrm{mM}$ ). Obviously additional structural elements are required for an efficient recognition of the substrate by carboxylase. A second group of substrates is formed by the "natural" substrates (substrates prepared from decarboxylated or non-carboxylated Gla-proteins). Descarboxyprothrombin fragment 13-29 (59) and d-osteocalcin (decarboxylated bone Gla protein) (60) have $K_{m}$ values between 1-10 $\mu \mathrm{M}$. Presumably the synthetic substrates are too small to bear a sufficient recognition site in their secondary structure. In this respect it is remarkable that the $K_{m}$ for the slightly larger descarboxyprothrombin fragment 13-29 is much lower. Apparently this polypeptide substrate contains a structural element, which is sufficient for the recognition by carboxylase. Another approach to study the enzyme-substrate interaction was the cloning of the cDNA of various Gla-containing proteins $(20,21,61-66)$. These studies have demonstrated that the primary translation product predicted from the cDNAsequences of the various Gla-proteins contains an amino-terminal extension of the mature protein sequence. This extension comprises a signal sequence for 


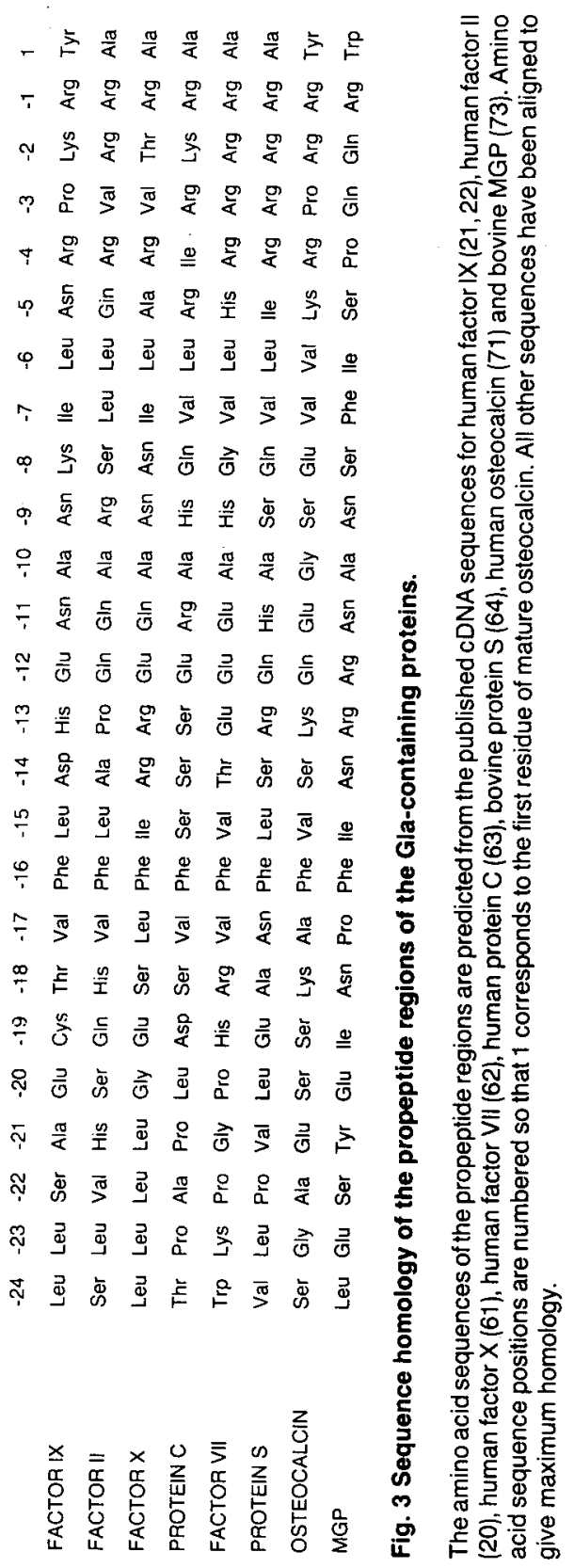


secretion and a basic propeptide sequence. The hydrophobic signal sequence is cleaved co-translationally and the pro-sequence is removed shortly before secretion. This is in agreement with observations of Swanson and Suttie, who reported the presence of intracellular prothrombin precursors having molecular weights corresponding to the prothrombin sequence with the propeptide attached (67). The amino acid sequence and length of the propeptide of the various Gla-containing proteins has been determined $(65,66,68-73)$. It turned out that a considerable sequence homology exists between the propeptides of the plasma Gla-containing proteins (fig. 3). It is remarkable that matrix Gla protein (MGP), a Gla-containing protein found in bone and synthesized by osteoblasts, has no propeptide. However, there is a region of the mature protein, residues -16 to -1 in fig. 3 , that is homologous to the propeptide of other Gla-containing proteins. It has been postulated by Pan and Price that this homologous propeptide domain plays a role in the enzyme-substrate interaction $(69,72)$.

Since the cDNA of various Gla-containing coagulation factors can be cloned in several cell lines, mutations may be introduced into the propeptide region of the recombinant clotting factors. Site-directed mutagenesis studies showed that the two conserved amino acid residues in the propeptide region of factor IX (phenylalanine at -16 and alanine at -10 ) are critical to recognition by the vitamin K-dependent carboxylase (74). Moreover, these studies have demonstrated that a recognition element located in the propeptide sequence is required for carboxylation of factor IX. Jorgensen et al. suggested that this $\gamma$-carboxylation recognition site $(\gamma$-CRS) interacts with a domain of the carboxylase separate from the catalytic site (74).

Recently, the same group reported the first description of the expression of recombinant prothrombin in which all of the expressed prothrombin is carboxylated (75). The development of a system for the expression of fully carboxylated, biologically active Gla-containing proteins may be an important step forward in the elucidation of the enzyme-substrate interaction.

All known Gla-containing proteins contain a second highly conserved sequence, the invariant unit Glu-X-X-X-Glu-X-Cys (fig. 4) (76). Although this particular amino acid sequence has been recognized recently, there is indirect evidence that it might play a role in the enzyme-substrate interaction $(54,77$ 79). This hypothesis is supported by the observation that decarboxylated osteocalcin and descarboxyprothrombin fragment 13-29 are excellent substrates in vitro $(59,60)$. Both substrates contain the sequence (Glu-X-X-X-Glu-C-Cys) but lack the propeptide domain. It is clear that the mechanisms involved in 


\begin{tabular}{|c|c|c|c|c|c|c|c|c|c|c|c|c|c|c|c|c|c|c|c|c|c|c|c|c|c|c|}
\hline & 1 & & & & & & & & 10 & & & & & & & & & 20 & & & & & & & & \\
\hline OSTEOCALCIN & $Y$ & L & Y & 0 & $w$ & & G A & $P$ & $v$ & $P$ & Y & $P$ & D & $P$ & $\mathrm{~L} \dot{\mathrm{E}}$ & $P$ & $R$ & $A \dot{E}$ & $v$ & $c$ & $\dot{E}$ & $\mathrm{~L}$ & $N$ & $P$ & D & C \\
\hline MGP & $R$ & A & k & A & 0 & $\dot{\mathrm{E}}$ & $8 \quad 1$ & B & $\dot{E}$ & L & $N$ & $\mathrm{~K}$ & $p$ & 0 & $\gamma \dot{\mathrm{E}}$ & $\mathrm{L}$ & $N$ & $R \dot{E}$ & A & $\mathrm{c}$ & D & D & $F$ & k & L & $c$ \\
\hline =ACTOR II & A & N & $T$ & $\mathrm{~F}$ & & I. & $\dot{E} \dot{E}$ & v & $R$ & $\mathrm{k}$ & $G$ & $N$ & L & $\dot{E}$ & $R \dot{E}$ & $c$ & $v$ & $\dot{E} \dot{E}$ & $T$ & $c$ & s & $Y$ & $\dot{E}$ & $\dot{\mathrm{E}}$ & A & $F$ \\
\hline FACTOR $X$ & A & $N$ & s & & $\mathrm{F}$ & L. & $\dot{E} \dot{E}$ & M & $k$ & $\mathrm{~K}$ & G & $\mathrm{H}$ & L & $\dot{E}$ & R $\dot{E}$ & $\mathrm{C}$ & $M$ & $\dot{E} \dot{E}$ & $T$ & $c$ & $s$ & $Y$ & $\dot{E}$ & $E$ & A & R \\
\hline =ACTORIX & $Y$ & $N$ & s & G & k & $\mathrm{L}$ & $\dot{E} \dot{E}$ & $\mathrm{~F}$ & v & 0 & $\mathrm{G}$ & $N$ & L & $\dot{\mathrm{E}}$ & $R \dot{E}$ & $\mathrm{c}$ & $M$ & $\dot{\varepsilon} \dot{E}$ & $k$ & $\mathrm{c}$ & $s$ & $F$ & $\dot{\mathrm{E}}$ & $E$ & A & A \\
\hline FACTOR VII & $A$ & $N$ & & A & $F$ & $\mathrm{~L}$ & $\dot{E} \dot{E}$ & L & $\mathrm{R}$ & $P$ & $\mathrm{G}$ & $s$ & L & $\dot{\mathrm{E}}$ & $R \dot{E}$ & $c$ & $\mathrm{k}$ & $\dot{E} \dot{E}$ & 0 & c & $s$ & $F$ & $\dot{E}$ & $E$ & A & R \\
\hline PROTEINS & A & $\mathrm{N}$ & $s$ & & L & $\mathrm{L}$ & $\dot{E} \dot{E}$ & $T$ & k & 0 & $G$ & $N$ & L & $\dot{E}$ & $R \dot{E}$ & $c$ & 1 & $\dot{E} \dot{E}$ & $\mathrm{~L}$ & c & $\mathrm{N}$ & $\mathrm{k}$ & $\dot{E}$ & $E$ & A & B \\
\hline PROTEINC & A & N & s & & $F$ & L & $\dot{E} \dot{E}$ & L & R & $\mathrm{H}$ & $s$ & $s$ & 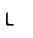 & E & $R$ & $\mathrm{c}$ & 1 & $\dot{E}$ & 1 & $\mathrm{c}$ & D & $F$ & $\dot{E}$ & $E$ & A & $k$ \\
\hline ROTEIN Z & A & G & s & Y & L & $\mathrm{L}$ & $\dot{E} \dot{E}$ & 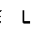 & & $E$ & G & $\mathrm{H}$ & $L$ & & $\mathrm{~K} \dot{\mathrm{E}}$ & $\mathrm{c}$ & 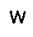 & $\dot{E} \dot{E}$ & 1 & & v & $\gamma$ & $\dot{E}$ & $\dot{\mathrm{E}}$ & & \\
\hline
\end{tabular}

Fig. 4 Conserved amino acids in the Gla-containing domains of various Gla-containing proteins.

Amino-acid sequence positions are numbered so that 1 corresponds to the first residue of mature osteocalcin. All other sequences have been aligned to give maximum homology. Sequences are given in standard one-letter symbols $(\dot{E}$ represents Gla). Sequences (from top to bottom): human osteocalcin (71); bovine MGP (73); human factor II (20); human factor X (61); human factor IX (21); human factor VII (62); bovine protein S (64); human protein C (63); bovine protein Z (93).

enzyme-substrate interaction are not completely understood yet and that further studies are required.

\section{IDENTIFICATION OF GLA-CONTAINING PROTEINS}

Except for the coagulation factors II, VII, IX and X blood plasma contains three more Gla-containing proteins, the proteins $\mathrm{C}, \mathrm{S}$ and $\mathrm{Z}$. Protein $\mathrm{C}$, synthesized in the liver, is a glycoprotein, consisting of two chains, the molecular weights of which are 41 and $21 \mathrm{kD}$, respectively (80). The light chain of the protein contains not only 11 Gla-residues but also one $\beta$-hydroxyaspartic acid residue (81). Protein $\mathrm{C}$ is synthesized as a single chain molecule consisting of 417 residues and is converted to its mature two-chain form posttranslationally (82). The protein circulates in plasma (concentration $=4-5$ $\mathrm{mg} / \mathrm{L}$ ) in a zymogen form and can be activated into a serine protease by proteolysis with thrombin $(83,84)$. Thrombin is converted into a potent activator after it has bound to the endothelial cell cofactor thrombomodulin. The anticoagulant action of activated protein $\mathrm{C}$ is due to a degradation of factors $\mathrm{Va}$ and VIIIa by limited proteolysis (84). The activity of activated protein $\mathrm{C}$ is enhanced by the presence of protein $\mathrm{S}$. Protein $\mathrm{S}$ is a glycoprotein consisting of a single polypeptide chain with a molecular weight of about 70 $\mathrm{kD}(85,86)$. It contains 11 Gla-residues at the $\mathrm{NH}_{2}$-terminal side and one $\beta$-hydroxyaspartic acid residue (87). The plasma concentration is approximately $25 \mathrm{mg} / \mathrm{L}(86)$. About $60 \%$ of protein $S$ circulates in a 1:1 complex with $\mathrm{C}_{4}$-binding protein (88). Only the unbound fraction of protein $\mathrm{S}$ serves as a 
cofactor for activated protein C (89). Both human and bovine endothelial cells (90) as well as human megakaryocytes (91) synthesize a biologically active protein $\mathrm{S}$.

Protein $\mathrm{Z}$, originally described as a single chain variant of factor $\mathrm{X}$ (92), is also a glycoprotein with a molecular weight of about $50 \mathrm{kD}(93,94)$. It contains 13 Gla-residues and one $\beta$-hydroxyaspartic acid residue. The plasma concentration of human protein $\mathrm{Z}$ is approximately $2.9 \mathrm{mg} / \mathrm{L}$ (95). Like protein $\mathrm{S}$, protein $\mathrm{Z}$ cannot be activated into a serine protease (e.g. by trypsin or thrombin). Unfortunately its function is not yet known.

The plasma Gla-containing proteins except prothrombin contain a second modified amino acid, $\beta$-hydroxyaspartic acid. Rencently Fowler et al. proposed that the $\beta$-hydroxyaspartic acid residue in factor IX is involved in binding of an iron atom (96). It has also been hypothesized that $\beta$ hydroxyaspartic acid is involved in $\mathrm{Ca}^{++}$ion binding in protein $\mathrm{C}$ and in the related vitamin $\mathrm{K}$-dependent proteins (97). A considerable sequence homology has been found between all the Gla-containing proteins occurring in blood plasma (94). In vitro these proteins bind rapidly to insoluble barium and calcium salts, but in vivo they exclusively occur dissolved in plasma. In the presence of calcium ions, they have a high affinity towards negatively charged phospholipid surfaces. Binding to these surfaces highly stimulates their enzyme activity (98).

The occurrence of Gla-containing proteins is not restricted to blood plasma (table I). Protein-bound Gla-residues have also been detected in the matrix of calcified tissues. Bone contains two Gla-proteins osteocalcin and MGP (99101). MGP consists of a single polypeptide chain, containing 79 amino acid residues and has a molecular weight of approximately $10 \mathrm{kD}$. It contains 5 Glaresidues and one disulfide bond. Osteocalcin will be discussed in more detail elsewhere.

As early as in 1976 Hauschka et al. reported the presence of a membranebound Gla-containing protein in the kidney. Although the protein was not further characterized, it might be similar or related to the Gla-containing protein found in calcium containing renal calculi $(31,102)$. This extremely acidic protein has a molecular weight of $17 \mathrm{kD}$ and contains 7 Gla-residues per molecule. Nakagawa et al. purified and partly characterized a Gla-containing protein from human urine (103). The origin of this protein, which was designated as Glycoprotein Crystallization Inhibitor (GCI) is not known at present.

Other Gla-containing proteins have been detected in dentin (104), coral (105) and in ectopic calcifications from patients with scleroderma and 
dermatomyositis (106). In spite of extensive studies, the function of these proteins has remained obscure till now. They may play a role in the regulation of the deposition of insoluble calcium salts. A similar function has been proposed for Gla-containing proteins occluded in the matrix of mollusc shells (107). Gla-containing proteins have also been discovered in the venoms from various snakes $(108,109)$ and Conus geographus $(110)$ and in spermatozoa (111).

TABLE I

Occurrence of Gla-containing proteins

\begin{tabular}{ll}
\hline A. Blood plasma & $\begin{array}{l}\text { Coagulation factors II, VII, IX and X } \\
\text { Proteins C, S and Z }\end{array}$ \\
B. Calcified tissue & $\begin{array}{l}\text { Bone } \\
\text { Dentin } \\
\text { Renal stones } \\
\text { Calcified lesions of the skin } \\
\text { Coral } \\
\text { Atherosclerotic plaque }\end{array}$ \\
C. Venoms from & $\begin{array}{l}\text { Notechis scutatus, Oxyuranus scutellatus } \\
\text { and Conus geographus }\end{array}$ \\
D. Others & $\begin{array}{l}\text { Spermatozoa } \\
\text { Chicken Egg } \\
\text { Urine }\end{array}$ \\
\end{tabular}

\section{ATHEROSCLEROSIS}

Cardiovascular disease remains the major cause of death in the United States and Western Europe. Atherosclerosis, the principal cause of myocardial and cerebral infarction, and thrombosis account for many of these deaths (112). Nevertheless their cause and pathogenesis remain unsolved. A major problem in studying atherogenesis is that the disease progresses gradually for many years before symptoms develop. This makes it very difficult to follow the early development of arteriosclerosis in individual patients. Risk factors, such as hypercholesterolemia, smoking, hypertension, diabetes, and behavioral patterns are associated with the increased incidence of atherosclerosis in Western populations. However, epidemiological studies suggest that these factors do not fully explain the extent and severity of the disease in man (113). Therefore other unidentified factors must contribute to the etiology and pathogenesis of human atherosclerosis. Various studies have suggested that herpes viruses may be amongst these unidentified factors $(114,115)$. In 
atherogenesis three types of lesion are classically recognized: the fatty streak, the fibrous plaque and the complicated lesion or calcified (atherosclerotic) plaque (116). The fatty streak, commonly found in young persons, is characterized by an accumulation of small numbers of intimal smooth muscle cells. These cells contain and are surrounded by lipid depositions. The most characteristic lesion of atherosclerosis is the fibrous plaque. This lesion, which protrudes into the lumen of the blood vessel, consists of accumulated intimal smooth muscle cells. The lipid component of these cells is mainly formed by cholesterol and cholesterylesters. The cells and the extracellular matrix components form a fibrous cap that covers a large debris. This debris consists of extracellular lipid as well as of dead and dying cells. In fact, this fatty debris provided the name atherosclerosis, which is derived from the Greek athèra (= gruel) and sclerosis (= hardening) (117). As atherosclerosis advances the fibrous plaque alters and becomes a calcified plaque. Usually this type of lesion is characterized by the presence of calcified areas in the vessel wall. The mechanism of this calcification is not yet understood. Several groups suggest that calcification in human atherosclerosis might be related to smooth muscle cell degeneration and that the major initial loci for calcium deposition are vesicles (118-120). These membrane-bound vesicles, derived from degraded smooth muscle cells, are morphologically similar to the matrix vesicles, described in other tissues $(121,122)$. At present it is not known whether the mineralization mechanism involved in atherosclerosis is different from the mechanism in bone and cartilage. Although the calcified plaque can close an artery by itself it initiates often the formation of a blood clot. A thrombus may develop as a result of either a slowing down of the blood flow or the presence of turbulescent regions in the fluid. The formation of a thrombus can lead ultimately to the occlusion of an artery by thrombosis.

As mentioned before, the cause and pathogenesis of atherosclerosis are still obscure. In the literature a number of hypotheses considering the etiology of atherogenesis are currently present. One hypothesis has been proposed by Benditt and Benditt (117). This so-called "monoclonal" hypothesis suggests that each lesion of atherosclerosis is derived from one single smooth muscle cell that serves as a progenitor for the remaining proliferative cells. A second hypothesis involves also smooth muscle cell proliferation and has been suggested by Martin and Sprague (123). This "clonal-senescence" hypothesis relates to aging, which is one of the well-known risk factors in atherosclerosis. The data obtained from their studies indicate that cells in culture replicate through a limited number of generations. This number is inversely related to the age of the donor $(124,125)$. The "response-to-injury" hypothesis, proposes 
that "injury" to the endothelium is the initiating event in atherogenesis $(112,126)$. A problematic aspect of this hypothesis is the need to define precisely endothelial injury. Many changes in injured endothelium may occur, without morphological manifestations (126). At least two pathways are involved in the formation of intimal smooth muscle cell proliferative lesions. One pathway as demonstrated in hypercholesterolemia (126), involves monocyte and possibly also platelet interactions. These interactions may result in the formation of a fibrous plaque. The second pathway involves direct stimulation of endothelium, which may release growth factors. These growth factors in turn can induce smooth muscle cell migration and proliferation, and possibly autogenous growth factor release by the stimulated smooth muscle cells. This pathway may play a role in diabetes, hypertension, cigarette smoking, or other circumstances associated with an increased incidence of atherosclerosis.

\section{GLA-CONTAINING PROTEINS ASSOCIATED WITH CARDIOVASCULAR CALCIFICATIONS}

As early as in 1976 it was reported by Lian et al. (106) that Gla-containing proteins may be found in ectopic calcifications, including calcified human atherosclerotic plaques. Three years later further data about the nature of one of these proteins were published by Levy and collegues (127-129), who isolated and partly characterized the Gla-protein from calcified plaques. The protein exhibited a high affinity to calcium ions and hence it was called atherocalcin. With its $\mathrm{M}_{\mathrm{r}}$ of $80 \mathrm{kD}$, its 12 Gla-residues per molecule and a $\mathrm{pI}$ between 4.16 and 4.3, atherocalcin was regarded to be very dissimilar from any of the Gla-proteins found in blood plasma. Recently, however, it became evident that atherocalcin consists of a tight complex between albumin and osteocalcin (130). Besides in calcified atherosclerotic plaques, Gla-containing proteins were also found in calcified cardiac valves (both in man as well as in the cow), but not in non-calcified vascular tissue (127, 131-133).

Little is known about the nature of the Gla-proteins present in the calcified material. Various authors have reported these proteins to be heterogeneous with a $\mathrm{M}_{\mathrm{r}}$ between 6 and $10 \mathrm{kD}(130,134)$. Osteocalcin (either complexed to albumin or free) contributes only for a small part to the total amount of protein-bound Gla-residues $(130,132,133)$, and other known Gla-proteins have not yet been detected in calcified plaque extracts. Also the origin of the Glaprotein in the mineralized lesions is uncertain. Obviously one might expect them to be adsorbed from the blood stream, because Gla-proteins are generally 
characterized by their high affinity to insoluble calcium salts. It is not yet sure, however, if plasma (lipo)proteins are able to infiltrate into the calcified atherosclerotic plaque (134-136) and it is at least striking, that the most abundant Gla-protein in plasma (prothrombin) has never been demonstrated in the mineralized tissue. Another hypothesis is that the Gla-proteins are formed as a result of a transformation of the cells in the affected areas of the vessel wall. Evidence supporting this hypothesis is the observation that atherosclerotic lesions predominantly contain collagen type I (which is normally present in bone), whereas normal vascular tissue contains collagen type III (137). Additionally Kim has described the presence of calcium-rich matrix vesicles in calcified valves and plaques (138). Similar organelles occur in endochondral bone. If this hypothesis is correct, one would expect that besides osteocalcin also MGP (the second Gla-protein in bone) would be found in vascular calcifications. As yet this has not been confirmed, however.

Also the function of the vascular Gla-proteins has remained unclear up till now. In vitro it has been shown that osteocalcin and other Gla-proteins prevent the formation of hydroxyapatite and the precipitation of various calcium salts $(9,99)$. It is well known, however, that organic macromolecules involved in the regulation of calcium salt crystallization, may sometimes exert a dual function: by a mechanism not yet completely understood they sometimes initiate the nucleation during crystal growth, whereas under different conditions the same molecules may bind to the surface of the forming crystal in such a way that they prevent further accretion of the mineral (99). Besides its possible role in the process of crystallization, osteocalcin has also been suggested to function in the chemotaxis of macrophages, monocytes and osteoclasts $(139,140)$. Since it is generally accepted that in atherosclerotic plaques the macrophages play an important role in lipid uptake and secretion of smooth muscle cell growthpromoting factors (140), osteocalcin present in these plaques may mediate the migration of macrophages into the growing atherosclerotic lesions.

\section{OSTEOCALCIN}

Osteocalcin, also called bone Gla protein, is a unique vitamin $\mathrm{K}$-dependent protein present in bone and dentin $(99,100,141,142)$. This calcium-binding protein is among the 6 most abundant proteins in man. In bone it comprises over $25 \%$ of the non-collagenous proteins. It contains 47-50 amino acid residues and has a molecular weight varying between $5.2-5.9 \mathrm{kD}$, depending on the species from which it is obtained (143). The protein contains 3 Glaresidues at positions 17,21 and 24 , respectively. In man only the two latter 
ones seem to be fully carboxylated (100). The single chain protein molecule has a disulfide bond between the Cys-residues at position 23 and 29 (144). Comparison of the amino acid sequence of osteocalcins from several species has revealed that the protein structure is highly conserved during evolution $(100,144,145)$.

Osteocalcin is synthesized in organ cultures of isolated bones, in rat osteoblast-like osteosarcoma cells (146) and also in a human osteosarcoma cell line derived from cells in a patient with Paget's disease (147). Osteocalcin secreted into the culture medium is identical to the osteocalcin purified from the bone matrix (146). Biosynthesis and secretion of osteocalcin from osteosarcoma cells is regulated by physiological levels of 1,24dihydroxyvitamin D3 (148). This hormone strongly stimulates the mobilization of bone calcium. Administration of warfarin to the culture medium results in the secretion of a noncarboxylated osteocalcin (146). Besides a decreased secretion rate, an accumulation of an intracellular precursor within the cell has been observed (69). Initially osteosarcoma cells synthesize a $9 \mathrm{kD}$ intracellular precursor, which is processed to the osteocalcin detected in the culture medium (149). Hauschka et al. reported the existence of higher molecular weight osteocalcin precursors in extracts of chicken bone (150). The component with an apparent molecular weight of $10 \mathrm{kD}$ may correspond to the intracellular precursor mentioned above. Studies have shown that $8 \mathrm{~h}$ after administration of warfarin, osteocalcin from bone is still fully carboxylated whereas serum osteocalcin is not. Osteocalcin is cleared from the blood rapidly by glomerular filtration (151). Although the major part of the newly synthesized osteocalcin remains bound to the bone, low concentrations circulate in blood and may be detected by radioimmuno assay (152).

Studies monitoring serum osteocalcin levels have revealed that an increase in the serum osteocalcin level generally correlates with an increase in alkaline phosphatase $(153,154)$ and that serum osteocalcin is markedly increased in many patients with metabolic bone disease (153,155-157). Brown et al. suggested that osteocalcin may be a specific marker for bone formation (156).

Osteocalcin appears in the developing bone at the same time as mineralization starts and reaches its highest concentration in the rapid growing parts of the bone $(158,159)$. Although the exact function of osteocalcin is not yet known, the protein has several properties which suggest that it might play an important role in bone metabolism (160). Some of these properties are 1) specific Gla-dependent binding of $\mathrm{Ca}^{++}$-ions (161); 2) a tight binding to hydroxyapaptite (HA), the primary mineral component of bone (161), as a result of the $\mathrm{Ca}^{++}$-induced transition to $\alpha$-helical conformation; 3 ) inhibition 
of HA formation in vitro (162). Additionally, osteocalcin has a chemotactic attractant activity towards macrophages (163) and monocytes (164). In vitro studies have shown that low concentrations of osteocalcin inhibit the precipitation of calcium phosphate from supersaturated solutions $(99,100,165)$. This precipitation-inhibitory activity of osteocalcin was lost after thermal decarboxylation of the protein-bound Gla-residues (79). If osteocalcin would have a similar function in vivo, it might be expected that it prevents excessive mineralization in bone. An example of such excessive mineralization is fetal warfarin syndrome (chondrodysplasia punctata), a well-known bone disease, characterized by bone abnormalities in the fetus (166). This disease may occur when women take coumarin derivatives during the first trimester of pregnancy. The absence of normal osteocalcin leads to the excessive precipitation of calcium phosphate in rapidly growing bone tissue. Price and Williamson have developed a model for analyzing the function of osteocalcin in bone metabolism and showed that rats can be maintained on warfarin without problems due to bleeding (167). In a recent study they have demonstrated that vitamin $\mathrm{K}$ counteracts the effect of warfarin on blood coagulation far more effectively than it counteracts the effect of warfarin on the binding of serum osteocalcin to HA (168). One of the possible explanations given by the authors is that the warfarin-insensitive NADH-dependent vitamin $\mathrm{K}$ reductase is far less active in bone cells than in hepatocytes. Recently, Ulrich et al. demonstrated that the NADH-dependent $\mathrm{K}$ reductase is absent in rat osteosarcoma UMR 106 and hence probably also in normal osteoblasts (169). This explains the observation of Price and Kaneda mentioned before.

\section{INTRODUCTION TO THIS THESIS}

Vitamin K-dependent carboxylase is found in a wide variety of tissues. These carboxylases may be regarded as a group of isoenzymes, which mainly differ in their substrate specificity. Recently, the reaction products of several non-hepatic carboxylating enzyme systems have been detected in various calcified tissues. Calcified atherosclerotic plaques, for instance, contain not only a small amount of osteocalcin but also an unidentified Gla-containing protein fraction. The function of the non-hepatic Gla-proteins, however, is not yet known. Comparison of the hepatic and non-hepatic carboxylase probably will give more insight in the function of the non-hepatic Gla-containing proteins. Since it is known that vitamin $\mathrm{K}$ antagonists, especially the 4hydroxycoumarin derivatives, are most popular in antithrombotic therapy, it is interesting to examine whether in vivo the degree of carboxylation of the non- 
hepatic Gla-containing proteins is affected. In this thesis we compare the carboxylating systems from liver and some non-hepatic tissues (mainly vessel wall) and the search for the physiological counterpart of DTT as a reducing agent in these systems is described. In the second part of this thesis we have focused our attention on the Gla-containing proteins found in calcified atherosclerotic plaques: osteocalcin and a hitherto unidentified protein, which was called plaque Gla-protein (PGP). In contrast to osteocalcin (which can be obtained from bone) the isolation and purification of PGP from calcified plaques appeared to be a laborious task. Because osteocalcin and PGP exhibit a number of similarities, however, osteocalcin was chosen as a model protein for the development of various assays which may be applied to PGP equally well.

\section{REFERENCES}

1. Dam, H. Biochem. J. 29: 1273-1285, 1935

2. Schofield, F.W. Can. Vet. Rec. 3: 74-79, 1922

3. Campbell, M.A. and Link, K.P. J. Biol. Chem. 18: 21-33, 1941

4. O'Reilly, R.A. Ann. Rev. Med. 27: 245-261, 1976

5. Soute, B.A.M., De Metz, M. and Vermeer, C. FEBS Lett. 146: 365-368, 1982

6. Vermeer, C., Hendrix, H. and Daemen, M. FEBS Lett. 148: 317-320, 1982

7. Stenflo, J., Fernlund, P., Egan, W. and Roepstorff, P. Proc. Natl. Acad. Sci (USA) 71: 2730-2733, 1974

8. Nelsestuen, G.L., Zytkovicz, T.H. and Howard, J.B. J. Biol. Chem. 249: 6347-6350, 1974

9. Suttie, J.W. CRC Crit. Rev. Biochem. 8: 191-223, 1980

10. Sperling, R., Furie, B.C., Blumenstein, M., Keyt, B. and Furie, B. J. Biol. Chem. 253: 3898-3906, 1978

11. Bloom, J.W. and Mann, K.G. Biochemistry 17:4430-4438, 1978

12. Nelsestuen, G.L. J. Biol. Chem. 251: 5648-5656, 1976

13. Marsh, H.C., Robertson, P., Scott, M.E., Koehler, K.A. and Hiskey, R.G. J. Biol. Chem. 254: 10268-10275, 1979

14. Tai, M.M., Furie, B.C. and Furie, B. J. Biol. Chem. 255: 2790-2795, 1980

15. Reekers, P.P.M., Lindhout, M.J., Kop-Klaassen, B.H.M. and Hemker, H.C. Biochim. Biophys. Acta 317: 559-562, 1974

16. Hemker, H.C., Veltkamp, J.J., Hensen, A. and Loeliger, E.A. Nature 200:589-590, 1963

17. Magnusson, S., Sottrup-Jensen, L., Petersen, T.E., Morris, H.R. and Dell, A. FEBS Lett. 44: 189-193, 1974

18. Walter, P. and Blobel, G. Nature 299: 691-698, 1982

19. Meyer, D.I., Krause, E. and Dobberstein, B. Nature 297: 647-650, 1982

20. Friezner Degen, S.J., MacGillivray, R.T.A. and Davie, E.W. Biochemistry 22: 2087 2097,1983

21. Kurachi, K. and Davie, E.W. Proc. Natl. Acad. Sci. (USA) 79: 6461-6464, 1982

22. Anson, D.S., Choo, K.H., Rees, D.J.G., Giannelli, F., Gould, K., Huddleston, J.A. and Brownlee, G. EMBO J. 3: 1053-1064, 1984

23. Esmon, C.T., Sadowski, J.A. and Suttie, J.W. J. Biol. Chem. 250: 4744-4748, 1975

24. Dubin, A., Suen, E.T., Delaney, R., Chiu, A. and Johnson, B.C. J. Biol. Chem. 255: 349-352, 1980

25. Shah, D.V., Swanson, J.C. and Suttie, J.W. Arch. Biochem. Biophys. 222: 216-221, 1983

26. Esmon, C.T. and Suttie, J.W. J. Biol. Chem. 251: 6238-6243, 1976 
27. Vermeer, C., Soute, B.A.M., De Metz, M. and Hemker, H.C. Biochim. Biophys. Acta 714: 361-365, 1982

28. Vermeer, C. Mol. Cell. Biochem. 61: 17-35, 1984

29. Shah, D.V., Swanson, J.C. and Suttie, J.W. Proc. Soc. Exp. Biol. Med. 161: 498-501, 1979

30. Thierry, M.J. and Suttie, J.W. J. Nutr. 27: 512-516, 1969

31. Hauschka, P.V., Friedman, P.A., Traverso, H.P. and Gallop, P.M. Biochem. Biophys. Res. Commun. 71: 1207-1231, 1976

32. Buchtal, S.D. and Bell, R.G. Biochemistry 22: 1077-1082, 1983

33. Bell, R.G. Arch. Biochem. Biophys. 203: 58-64, 1980

34. Buchtal, S.D. McAllister, C.G., Laux, D.C. and Bell, R.G. Biochem. Biophys. Res. Commun. 109: 55-62, 1982

35. Friedman, P.A., Hauschka, P.V., Shia, M.A. and Wallace, J.K. Biochim. Biophys. Acta 583: 261-265, 1979

36. Roncaglioni, M.C., Dalessandro, A.P.B., Casali, B., Vermeer, C. and Donati, M.B. Haemostasis 16: 295-299, 1986

37. Nishimoto, S.K. and Price, P.A. J. Biol. Chem. 254: 437-441, 1979

38. Traverso, H.P., Hauschka, P.V. and Gallop, P.M. In: Vitamin K Metabolism and Vitamin K Dependent Proteins (Suttie, J.W., ed.) pp. 311-314, 1980. Univ. Park Press, Baltimore

39. De Boer-van den Berg, M.A.G., Uitendaal, M.P. and Vermeer, C. Mol. Cell. Biochem. 75: 71-76, 1987

40. Suttie, J.W. and Preusch, P.C. Haemostasis 16: 193-215, 1986

41. Olson, R.E. Ann. Rev. Nutr. 4: 281-337, 1984

42. Willingham, A.K. and Matschiner, J.T. Biochem. J. 140: 435-441, 1974

43. Suttie, J.W., Geweke, L.O., Martin, S. and Willingham, A.K. FEBS Lett. 109: 267270,1980

44. Whitlon, D.S., Sadowski, J.A. and Suttie, J.W. Biochemistry 17: 1371-1377, 1978

45. Matschiner, J.T., Zimmerman, A. and Bell, R.G. Thromb. Diath. Haemorrh. (Suppl. 57): 45-52, 1974

46. Wallin, R., Gebhardt, O. and Prydz, H. Biochem. J. 169: 95-101, 1978

47. Fasco, M.J. and Principe, L.M. J. Biol. Chem. 257: 4894-4901, 1982

48. Lee, J.J. and Fasco, M.J. Biochemistry 23: 2246-2252, 1984

49. Fasco, M.J. and Principe, L.M. Biochem. Biophys. Res. Commun. 97: 1487-1492, 1980

50. Wallin, R. Thromb. Haemost. 54: 150, 1985

51. Roncaglioni, M.C., Ulrich, M.M.W., Muller, A.D., Soute, B.A.M., De Boer-van den Berg, M.A.G. and Vermeer, C. Thromb. Res. 42: 727-736, 1986

52. Bell, R.G. Fed. Proc. 37: 2599-2604, 1978

53. Jackson, C.M. and Nemerson, Y. Ann. Rev. Biochem. 49: 765-811, 1980

54. Rich, D.H., Lehrman, S.R., Kawai, M., Goodman, H.L. and Suttie, J.W. J. Med. Chem. 24: 706-711, 1981

55. Rich, D.H., Kawai, M., Goodman, H.L. and Suttie, J.W. J. Med. Chem. 26: 910-916, 1983

56. Suttie, J.W., Hageman, J.M., Lehrman, S.R. and Rich, D.H. J. Biol. Chem. 251: $5827-5830,1976$

57. Suttie, J.W., Lehrman, S.R., Geweke, L.O., Hageman, J.M. and Rich, D.H. Biochem. Biophys. Res. Commun. 86: 500-507, 1979

58. Houser, R.M., Corey, D.J., Dus, K.M., Marshall, G.R. and Olson, R.E. FEBS Lett. 75: 226-230, 1977

59. Soute, B.A.M., Vermeer, C., De Metz, M., Hemker, H.C. and Lijnen, H.R. Biochim. Biophys. Acta 676: 101-107, 1981

60. Vermeer, C., Soute, B.A.M., Hendrix, H. and De Boer-van den Berg, M.A.G. FEBS Lett. 165: 16-20, 1984

61. Fung, M.R., Hay, C.W. and MacGillivray, R.T.A. Proc. Natl. Acad. Sci (USA) 82: 3591-3595, 1985

62. Hagen, F.S., Gray, C.L., O'Hara, P., Grant, F.J., Saari, G.C., Woodbury, R.G., Hart, C.E., Insley, M., Kisiel, W., Kurachi, K. and Davie, E.W. Proc. Natl. Acad. Sci (USA) 83: 2412-2416, 1986 
63. Foster, D.C., Yoshitake, S. and Davie, E.W. Proc. Natl. Acad. Sci (USA) 82: 46734677, 1985

64. Dahlbäck, B., Lundwall, $\AA$ and Stenflo, J. Proc. Natl. Acad. Sci (USA) 83: 4199-4203, 1986

65. Diuguid, D.L., Rabiet, M-J., Furie, B.C., Liebman, H.A. and Furie, B. Proc. Natl. Acad. Sci (USA) 83: 5803-5807, 1986

66. Bentley, A.K., Rees, D.J.G., Rizza, C. and Brownlee, G.C. Cell 45: 343-348, 1986

67. Swanson, J.C. and Suttie, J.W. Biochemistry 21: 6011-6018, 1982

68. Ware, J., Liebman, H.A., Kasper, C., Graham, J., Furie, B.C., Furie, B. and Stafford, D. Blood 68: 343a, 1986

69. Pan, L.C., Williamson, M.K. and Price, P.A. J. Biol. Chem. 260: 13398-13401, 1985

70. Blanchard, R.A., Faye, K.L.K. and Barnett, J.M. Blood 66: 331a, 1985

71. Celeste, A.J., Rosen, V., Buecker, J.L., Kriz, R., Wang, E.A. and Wozney, J.M. EMBO J. 5: 1885-1890, 1986

72. Pan, L.C. and Price, P.A. Proc. Natl. Acad. Sci (USA) 82: 6109-6113, 1985

73. Price, P.A. and Williamson, M.K. J. Biol. Chem. 260: 14971-14975, 1985

74. Jorgensen, M.J., Cantor, A.B., Furie, B.C., Brown, C.L., Shoemaker, C.B. and Furie, B. Cell 48: 185-191, 1987

75. Jorgensen, M.J., Cantor, A.B., Furie, B.C. and Furie, B. J. Biol. Chem. 262: 67296734, 1987

76. Price, P.A., Fraser, J.D. and Metz-Virca, G. Proc. Natl. Acad. Sci (USA) 84: 83358339,1987

77. De Boer-van den Berg, M.A.G., Ulrich M.M.W., Hemker, H.C., Soute, B.A.M. and Vermeer, C. Biochim. Biophys. Acta 831: 94-98, 1985.

78. Ulrich, M.M.W., Soute, B.A.M., De Boer-van den Berg, M.A.G. and Vermeer, C. Biochim. Biophys. Acta 830: 105-108, 1985.

79. Poser, J.W. and Price, P.A. J.Biol.Chem. 254: 431-436, 1979.

80. Stenflo, J. J.Biol. Chem. 251: 355-363, 1976.

81. Fernlund, P. and Stenflo, J. J.Biol.Chem. 258: 12509-12512, 1983.

82. Long, G.L. Belagaje, R.M. and Mac Gillivray, R.T.A. Proc. Natl. Acad. Sci (USA) 81: 5653-5656, 1984

83. Kisiel, W. J. Clin. Invest. 64: 761-769, 1979.

84. Kisiel, W., Canfield, W.M., Ericsson, C.H. and Davie, E.W. Biochemistry 16: 58245831,1977

85. DiScipio, R.G., Hermodson, M.A., Yates, S.G. and Davie, E.W. Biochemistry 16: 698-706, 1977.

86. Dahlbäck, B. Biochem. J. 209: 837-846, 1983

87. Stenflo, J., Lundwall, $\AA$. and Dahlbäck, B. Proc. Natl. Acad. Sci (USA) 84: 368-372, 1987

88. Dahlbäck, B., Smith, C.A. and Müller-Eberhard, H.J. Proc. Natl. Acad. Sci (USA) 80: 3461-3465, 1983

89. Dahlbäck, B. J. Biol. Chem. 261: 12022-12027

90. Fair, D.S., Marlar, R.A. and Levin, E.G. Blood 67: 1168-1171, 1986

91. Ogura, M., Tanabe, N., Nishioka, J., Suzuki, K. and Saito, H. Blood 70: 301-306, 1987

92. Prowse, C.V. and Esnouf, M.P., Biochem. Soc. Trans. 5: 255-256, 1977

93. Hørjup, P., Jensen, M.S. and Petersen, T.E. FEBS Lett. 184: 333-338, 1985

94. Hørjup, P., Roepstorf, P. and Petersen, T.E. Eur. J. Biochem. 126: 343-348, 1982

95. Miletich, J.P. and Broze, G.J. Blood 69: 1580-1586, 1987

96. Fowler, S.A., Paulson, D., Owen, B.A. and Owen, W.G. J. Biol. Chem. 261: 43714372, 1986

97. Sugo, T., Björk, I., Holmgren, A. and Stenflo, J. J. Biol. Chem. 259: 5705-5710, 1984

98. Rosing, J., Tans, G., Govers-Riemslag, J.W.P., Zwaal, R.F.A. and Hemker, H.C. J. Biol. Chem. 255: 274-283, 1980

99. Price, P.A., Otsuka, A.S., Poser, J.W., Kristaponis, J. and Raman, N. Proc. Natl. Acad. Sci (USA) 73: 1447-1451, 1976

100. Poser, J.W., Esch, F.S., Ling, N.C. and Price, P.A. J. Biol. Chem. 255: 8685-8691, 1980 
101. Price, P.A., Urist, M.R. and Otawara, Y. Biochem. Biophys. Res. Commun. 117: 765771,1983

102. Lian, J.B., Prien, E.L., Glimcher, M.J. and Gallop, P.M. J. Clin. Invest. 59: 11511157,1977

103. Nakagawa, Y., Abram, V., Kezdy, E.T., Kaiser, F. and Coe, L. J. Biol. Chem. 257: 12594-12600, 1983

104. Linde, A., Bhown, M., Cothran, W.C., Höglund, A. and Butler, W.F. Biochim. Biophys. Acta 704: 235-239, 1982

105. Hamilton, S.E., King, G., Tesch, D., Riddles, P.W., Keough, D.T., Jell, J. and Zerner, B. Biochem. Biophys. Res. Commun. 108: 610-613, 1982

106. Lian, J.B., Skinner, M., Glimcher, M.J. and Gallop, P.M. Biochem. Biophys. Res. Commun. 73: 349-355, 1976

107. Wheeler, A.P., George, J.W. and Evans, C.A. Science 212: 1397-1398, 1981

108. Tans, G., Govers-Riemslag, J.W.P., Van Rijn, J.L.M.L. and Rosing, J. J. Biol. Chem. 260: 9366-9372, 1985

109. Speijer, H., Govers-Riemslag, J.W.P., Zwaal, R.F.A. and Rosing, J. J. Biol. Chem. 261: 13258-13267, 1986

110. McIntosh, J.M., Olivera, B.M., Cruz, L.J. and Gray, W.R. J. Biol. Chem. 259: 1434314346, 1984

111. Soute, B.A.M., Müller-Esterl, W., De Boer-van den Berg, M.A.G. and Vermeer, C. FEBS Lett. 190: 137-141, 1985

112. Ross, R. and Glomset, J.A. N. Engl. J. Med. 295: 369-377; 420-425, 1976

113. Gordon, T., Garcia-Palmieri, M.R., Kagan, A., Kannel, W.B. and Schiffman, J. J. Chronic. Dis. 27: 329-344, 1984

114. Benditt, E.P., Barrett, T. and McDougall, J.K. Proc. Natl. Acad. Sci. (USA) 80: 63866389,1983

115. Minick, C.R., Fabricant, C.G., Fabricant, J. and Litrenta, M.M. Am. J. Pathol. 96: 673-706, 1979

116. Atherosclerosis: A report by the National Heart and Lung Institute Task Force on Atherosclerosis (DHEW publication No. NIH) pp. 72-219, 1971. Washington, Govern. Print Off.

117. Benditt, E.P. and Benditt, J.M. Proc. Natl. Acad. Sci (USA) 70: 1753-1756, 1973

118. Kim, K.M. Fed. Proc. 35: 156-162, 1976

119. Kim. K.M. and Huang, S.N. Lab. Invest. 25: 357-366, 1975

120. Tanimura, A., McGregor, D.H. and Anderson, H.C. Proc. Soc. Exp. Biol. Med. 172: $173-177,1983$

121. Anderson, H.C. J. Cell. Biol. 35: 81-101, 1967

122. Bonucci, E. Z. Zellforsch. Mikrosk. Anat. 103: 192-217, 1970

123. Martin, G.M. and Sprague, C.A. Exp. Mol. Pathol. 18: 125-141, 1973

124. Martin, G.M., Ogburn, C. and Sprague, C.A. In: Senescence and Vascular Disease. Exploration in aging (Cristafaldo, V.J., Roberts, J. and Adelman, R.C., eds.) pp. 163193, 1975. Plenum Press, New York

125. Hayflick, L. Exp. Cell. Res. 37: 614-636, 1965

126. Ross, R. N. Engl. J. Med. 314: 488-499, 1986

127. Levy, R.J., Lian, J.B. and Gallop, P.M. Biochem. Biophys. Res. Commun. 91: 41-49, 1979

128. Deyl, Z., Macek, K., Vancikova, O. and Adam, M. Biochim. Biophys. Acta 581: $307-$ 315,1979

129. Levy, R.J., Lian, J.B. and Gallop, P.M. In: Vitamin K Metabolism and Vitamin K Dependent Proteins, (Suttie, J.W., ed.) pp. 269-273, 1980. Univ. Park Press, Baltimore

130. Levy, R.J., Howard, S.L. and Oshry, L.J. Atherosclerosis 59: 155-160, 1986

131. Levy, R.J., Zenker, J.A. and Lian, J.B. J. Clin. Invest. 65: 563-566, 1980

132. Levy, R.J., Zenker, J.A. and Bernhard, W.F. Ann. Thorac. Surg. 36: 187-191, 1983

133. Levy, R.J., Gundberg, C. and Scheinman, R. Atherosclerosis 46: 49-56, 1983

134. Keeley F.W. and Sitarz, E.E. Atherosclerosis 46: 29-40, 1983

135. Hollander, W., Colombo, M.A., Kirkpatrick, B. and Paddock, J. Atherosclerosis 34: 391-405, 1979

136. Keeley, F.W. and Sitarz, E.E. Atherosclerosis 55: 63-69, 1985

137. McCullagh, K.A. and Balian, G. Nature 358: 73-75, 1975 
138. Kim, K.M., Valigorsky, J.M., Mergner, W.J., Jones, R.T., Pendergrass, R.F. and Trump, B.F. Human Path. 7: 47-60, 1976

139. Malone, J.D., Kahn, A.J., Griffin, G.L., Senior, R.M. and Teitelbaum, S.L. Amer. Soc. Orthoped. Res. 25A (Abstr.), 1980

140. Polverini, P.J., Cotran, R.S., Gimbrone, M.A. and Unanue, E.R. Nature 269: 804806,1977

141. Hauschka, P.V., Lian, J.B. and Gallop, P.M. Proc. Natl. Acad. Sci. (USA) 72: 3925 3929,1975

142. Bronckers, A.L.J.J., Gay, S., Dimuzio, M.T. and Butler, W.T. Coll. Rel. Res. 5: 273281,1985

143. Hauschka, P.V. Haemostasis 16: 258-272, 1986

144. Price, P.A., Poser, J.W. and Raman, N. Proc. Natl. Acad. Sci. (USA) 73: 3374-3375, 1976

145. Hauschka, P.V., Carr, S.A. and Biemann, K. Biochemistry 21: 638-642, 1982

146. Nishimoto, S.K. and Price, P.A. J. Biol. Chem. 255: 6579-6583, 1980

147. Kaplan, G.C., Eilon, G., Poser, J.W. and Jacobs, J.W. Endocrinology 117: 12351238,1985

148. Price, P.A. and Baukol, S.A. J. Biol. Chem. 255: 11660-11663, 1980

149. Nishimoto, S.K. and Price, P.A. J. Biol. Chem. 260: 2832-2836, 1985

150. Hauschka, P.V., Frenkel, J., DeMuth, R. and Gundberg, C.M. J. Biol. Chem. 258: 176-182, 1983

151. Price, P.A., Williamson, M.K. and Lothringer, J.W. J. Biol. Chem. 258: 176-182, 1983

152. Price, P.A. and Nishimoto, S.K. Proc. Natl. Acad. Sci. (USA) 77: 2234-2238, 1980

153. Price, P.A., Parthemore, J.G. and Deftos, L.J. J. Clin. Invest. 66: $878-883,1980$

154. Delmas, P.D., Stenner, P., Wahner, H.W. and Mann, K.G. J. Clin. Invest. 71: 13161321,1983

155. Deftos, L.J., Parthemore, J.G. and Price, P.A. Calcif. Tissue Int. 34: 121-124, 1982

156. Brown, J.P., Malaval, L., Chapuy, M.C., Delmas, P.D., Edouard, C. and Meunier, P.J. Lancet 1: 1091-1093, 1984

157. Epstein, S., McClintock, R., Bryce, G., Poser, J., Johnston, C.C. and Hui, S. Lancet 1: 307-310, 1984

158. Price, P.A., Lothringer, J.W., Baukol, S.A. and Reddi, A.H. J. Biol. Chem. 256: 3781-3784, 1981

159. Lian, J.B., Glimcher, M.J., Roufosse, A.H., Hauschka, P.V., Gallop, P.M., CohenSolal, L. and Reit, B. J. Biol. Chem. 257: 4999-5003, 1982

160. Gallop, P.M., Lian, J.B. and Hauschka, P.V. N. Engl. J. Med. 302: 1460-1466, 1980

161. Hauschka, P.V. and Carr, S.A. Biochemistry 21: 2538-2547, 1982

162. Hauschka, P.V. and Gallop, P.M. In: Calcium-Binding Proteins and Calcium Function (Wasserman, R.H., Corradino, R.A., Carafoli, E., Kretsinger, R.H., MacLennan, D.H. and Siegel, F.L., eds.) pp. 338-347, 1977. Elsevier/North Holland, Biomed. Press, Amsterdam

163. Malone, J.D., Teitelbaum, S.L., Griffin, G.L., Senior, R.M. and Kahn, A.J. J. Cell. Biol. 92: 227-230, 1982

164. Mundy, G.R. and Poser, J.W. Calcif. Tissue Int. 35: 164-168, 1983

165. Romberg, R.W., Werness, P.G., Riggs, B.L. and Mann, K.G. Biochemistry 25: 11761180,1986

166. Matschiner, J.T., Bell, R.G., Amelotti, J.M. and Knauer, T.E. Biochim. Biophys. Acta 201: 309-315, 1970

167. Price, P.A. and Williamson, M.K. J. Biol. Chem. 256: 12754-12759, 1981

168. Price, P.A. and Kaneda, Y. Thromb. Res. 46: 121-131, 1987

169. Ulrich, M.M.W., Knapen, M.H.J., Herrmann-Erlee, M.P.M. and Vermeer, C. Thromb. Res. 50: 27-32, 1988 
CHAPTER 2

SOME PROPERTIES OF THE HEPATIC AND NON-HEPATIC VITAMIN K-DEPENDENT ENZYME REACTIONS 
2A

\section{SUBSTRATE RECOGNITION BY VITAMIN K-DEPENDENT CARBOXYLASE}

Magda M.W. Ulrich, Berry A.M. Soute, L. Johan M. van Haarlem and Cees Vermeer

\section{SUMMARY}

Decarboxylated osteocalcins were prepared and purified from bovine, chicken, human and monkey bones and assayed for their ability to serve as a substrate for vitamin K-dependent carboxylase from bovine liver. Substantial differences were observed, especially between bovine and monkey d-osteocalcin. Since these substrates differ only in their amino acid residues 3 and 4 , it seems that these residues play a role in the recognition of a substrate by hepatic carboxylase.

\section{INTRODUCTION}

Secretory proteins are synthesized in the form of precursors, consisting of the amino acid residues found in the mature protein and, in addition, a leader sequence at the $\mathrm{N}$-terminal site of the polypeptide chain. The leader sequence contains 20-30 rather hydrophobic amino acid residues, which form the message required for translocation through the endoplasmic membrane $(1,2)$ 
and which are generally referred to as the pre-segment. In precursors of 4carboxyglutamic acid (Gla)-containing proteins (which are all secretory proteins), the pre-segment is followed by a second cluster of about 15 amino acid residues (3-5), which is called the pro-segment. It is generally assumed that the latter is required for the recognition of the nascent protein chain by vitamin K-dependent carboxylase. Since the first Gla-residue in the blood coagulation factors is found at position 6 (factors VII and X, proteins $\mathrm{C}$ and S) or 7 (factors II and IX), it seems that the pre-segment as well as the signal for recognition by carboxylase (the pro-part) are cleft off during the maturation of these proteins. Hence it was to be expected, that in their decarboxylated form the maturated proteins would not be efficiently recognized by carboxylase. Indeed very high $K_{m}$ values $(0.5-1.0 \mathrm{mM})$ have been observed for the carboxylation of the descarboxyfactors II and $\mathrm{X}$ in a liver cell-free system $(6,7)$.

Another Gla-containing protein is osteocalcin, a protein which abundantly occurs in bone $(8,9)$. During evolution osteocalcin has been conserved remarkably well, so that a very high sequence homology exists between the osteocalcins from different species (10). Also precursors to osteocalcin contain a propeptide, which even exhibits a certain sequence homology (at the positions $-16,-4$ and -1 ) with the propeptide of the Gla-containing coagulation factors $(11,12)$. This propeptide is not found in mature osteocalcin and hence it was not present in any of the substrates used in the experiments described below.

A difference between osteocalcin and the Gla-containing coagulation factors is that in osteocalcin the first Gla-residue in osteocalcin is only found at position 17 or later. Therefore it seemed at least possible that osteocalcins could be found containing an $\mathrm{NH}_{2}$-terminal structure which partly mimics the pro-segment of the Gla-containing blood coagulation factors and which therefore might be recognized by the hepatic vitamin K-dependent carboxylase. At first sight this hypothesis seems to be highly improbable, but initial experiments showed that decarboxylated osteocalcin from bovine bone could be carboxylated by bovine liver carboxylase (13). The low $K_{m}$ values which were found for this substrate indicated that it was efficiently recognized by carboxylase (14). Obviously this system is an artificial one, but it is extremely useful to study the importance of the amino acid sequence in decarboxylated osteocalcin for its recognition and carboxylation by hepatic carboxylase. Therefore we have started to purify osteocalcins from different species and of known amino acid sequences. In their decarboxylated form these osteocalcins were used as substrates for hepatic carboxylase and because of their high degree of sequence homology this technique provided us the opportunity to 
study the effect of small variations in the amino acid sequence on the carboxylation rate. The results of these investigations are presented in this paper.

\section{MATERIAL AND METHODS}

\section{Chemicals}

Vitamin $\mathrm{K}_{1}$ (Konakion) was obtained from Hoffmann-La Roche (Basel, Switzerland) and used in its hydroquinone form (7). Dithiothreitol and CHAPS were from Sigma (St. Louis, U.S.A.) and $\mathrm{NaH}^{14} \mathrm{CO}_{3}(40-60 \mathrm{Ci} / \mathrm{mol})$ was from Amersham International (U.K.). QAE-Sephadex was purchased from Pharmacia (Uppsala, Sweden). All other chemicals were from Merck (Darmstadt, F.R.G.).

\section{Preparation of decarboxylated osteocalcins}

Fresh femurs and tibias were obtained from cows, chickens, monkeys and humans. The bones were carefully cleaned, heated at $120^{\circ} \mathrm{C}$ overnight and ground to powder mechanically. The powder was extracted for $48 \mathrm{~h}$ with an EDTA-containing buffer (13) and the extract was diluted 10-fold with distilled water. Osteocalcin was isolated from the solution by batchwise adsorption onto QAE-Sephadex (5 ml slurry per litre diluted extract) and subsequent high salt elution. The eluate was desalted by dialysis against distilled water and osteocalcin was purified therefrom by high performance liquid chromatography (HPLC) using a Mono Q anion-exchange column (Pharmacia) and a Spherogel TSK $2000 \mathrm{SW}$ size-exclusion column (Beckman) as was described earlier for bovine osteocalcin (13). The presence of osteocalcin in the various fractions was determined with a radioimmuno assay (Immuno Nuclear Company). The purified osteocalcins were dialyzed against distilled water and submitted to thermal decarboxylation (13).

\section{Various assays}

Vitamin K-dependent carboxylase was prepared from normal bovine liver (6) and the carboxylase activity was measured by the incorporation of ${ }^{14} \mathrm{CO}_{2}$ into exogenous substrates in the presence of vitamin $\mathrm{K}$ hydroquinone (7). Protein concentrations were determined as in (15) and Gla and Glu residues 
were determined by alkaline hydrolysis of the proteins and subsequent HPLC analysis on a Nucleosil 5 SB column (Chrompack) as in (16). The $\mathrm{N}$-terminal amino acids were identified as described in (17).

\section{RESULTS}

Osteocalcin was prepared from monkey, chicken, human and bovine bones. The complete amino acid sequence of these osteocalcins has been reported elsewhere (10). As decided from their Gla/Glu ratio the various preparations were more than $90 \%$ pure. After thermal decarboxylation no Gla could be

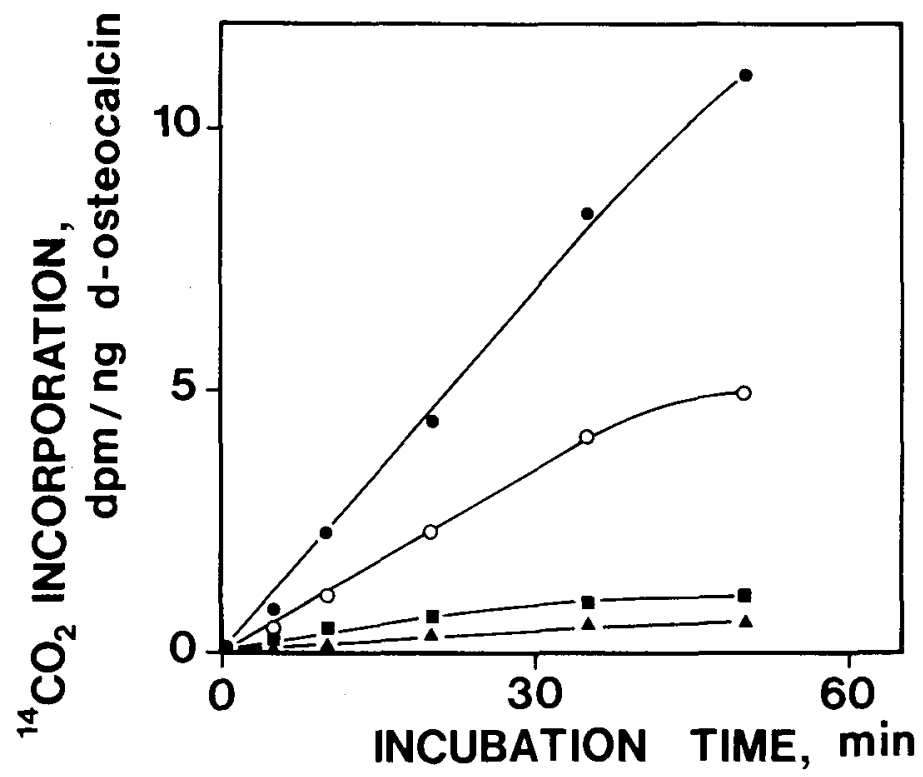

Fig. 1. Carboxylation of d-osteocalcins: time-course experiments.

D-osteocalcins from various species were incubated in the presence of solubilized bovine liver microsomes under the conditions known to be optimal for the carboxylation of exogenous substrates (7). The various d-osteocalcins were added to the reaction mixtures at a final concentration of $0.02 \mathrm{mg} / \mathrm{ml}$. D-osteocalcin was

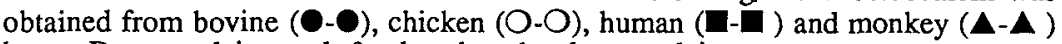
bones. D-osteocalcin stands for decarboxylated osteocalcin. 
detected anymore. To check whether other alterations had been introduced in the osteocalcins during the heat treatment required for their decarboxylation, we have made two additional controls. In the first place the $\mathrm{N}$-terminal amino acid residues were determined before and after decarboxylation. In each case only one residue was found being tyrosine for human, bovine and monkey osteocalcin and histidine for chicken osteocalcin. This shows that the polypeptide chains had remained intact and it is an additional proof of the purity of the various preparations. A second control experiment was the comparison of the molecular mass of the various preparations before and after thermal decarboxylation. This was performed by HPLC analysis on a size- exclusion column (TSK $2000 \mathrm{SW}$ ) and it turned out that the elution times of the osteocalcins had not been changed by the heat treatment.

The decarboxylated proteins were added to standard reaction mixtures containing detergent-solubilized carboxylase from bovine liver. Time-course experiments under conditions known to be optimal for the carboxylation of decarboxylated bovine osteocalcin showed substantial differences between the rates with which the various substrates were carboxylated (fig. 1). Moreover, all reaction rates were constant for at least $30 \mathrm{~min}$. Therefore this incubation period was used for the experiments described below. To exclude the possibi-

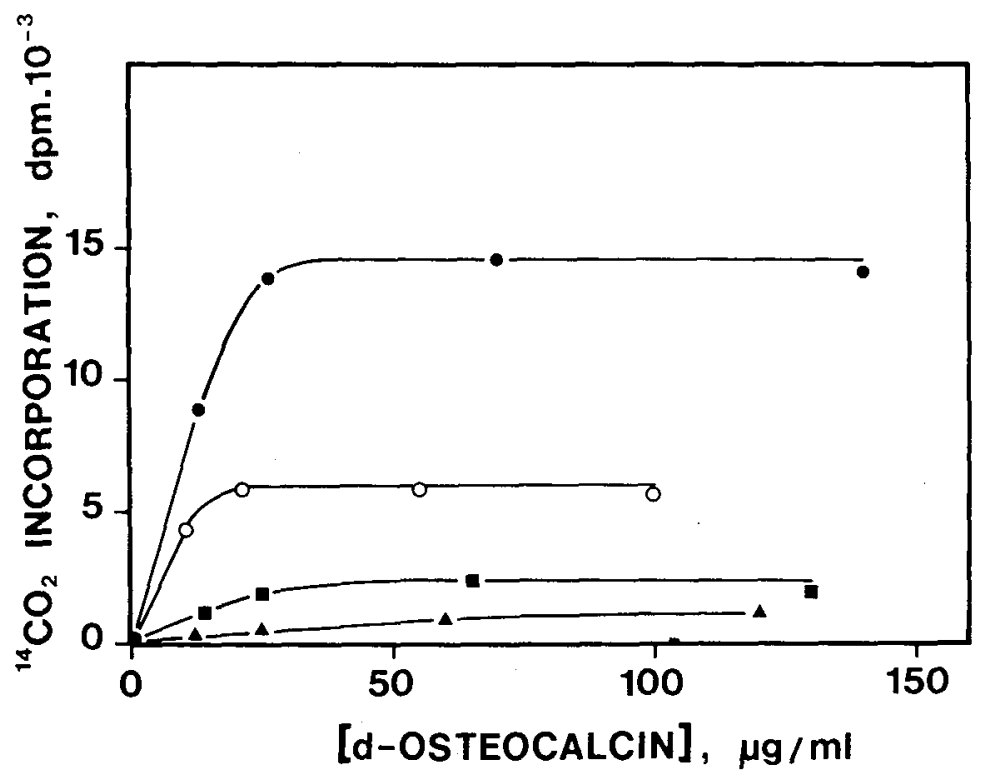

Fig. 2. Carboxylation of d-osteocalcins: concentration dependence.

The various $d$-osteocalcins were incubated for $30 \mathrm{~min}$ in the presence of bovine liver microsomes under the conditions known to be optimal for the carboxylation of exogenous substrates.For symbols see the legend to fig. 1. 
lity that the low carboxylation rate of decarboxylated monkey osteocalcin was due to the presence of an inhibitor, control experiments were performed in which the bovine substrate was mixed in various proportions with the monkey substrate. It turned out that decarboxylated monkey osteocalcin did not influence the carboxylation of the bovine substrate.

In a subsequent experiment we investigated the relation between the substrate concentration and the carboxylation rate (fig. 2). Whereas again decarboxylated bovine osteocalcin was a good substrate for both types of carboxylase, decarboxylated human and monkey osteocalcin were hardly carboxylated under our experimental conditions. Intermediate values were found for decarboxylated chicken osteocalcin. Similar results were obtained in carboxylase from human liver (data not shown).

$\begin{array}{lllll}1 & 5 & 10 & 15 & 20\end{array}$

Cow YLDHWLGAOAPYPDPLXPKRXVX... Monkey YLYQWLGAOAPYPDPLXPKRXVCX... Man YLYQWLGAPVPYPDPLXPRRXVCX... Chicken HYAQDSGVAAGAPPNPIXAQRXVCX...

Fig. 3. N-terminal sequence of osteocalcin from four different species.

The sequences are in the one-letter code and have been completely elucidated (10).

$\mathrm{O}$ stands for hydroxyproline and $\mathrm{X}$ for Gla.

These results prompted us to compare the primary structures of the $\mathrm{N}$ terminal part of osteocalcin from the various species. As shown in fig. 3 there is a striking sequence homology between monkey, human and bovine osteocalcin. The main differences are found at positions 3 and 4 , which in the case of bovine osteocalcin bear a negative and a positive charge, respectively. In monkey and human osteocalcin, on the other hand, these amino acid residues are neutral. A complete homology has been reported for the rest of the 49 amino acid residues in bovine and monkey osteocalcin (10). One of the explanations possible is, that the two oppositely charged amino acid residues in decarboxylated bovine osteocalcin are part of a recognition signal for carboxylase. Therefore it is striking that decarboxylated chicken osteocalcin bearing only the positive charge at position 4 , showed an intermediate substrate activity. Since chicken osteocalcin differs from the monkey and the bovine molecule also at some other places, no definite conclusions can be drawn from this observation, however. 


\section{DISCUSSION}

Although vitamin $\mathrm{K}$-dependent carboxylase has been discovered more than 10 years ago (18), the enzyme has not yet been purified to a reasonable extent. Up till now all investigations concerning carboxylase have been performed therefore at best in only partly purified systems. This is a serious drawback, especially for the elucidation of the carboxylation reaction mechanism.

Other aspects of carboxylase, however, may also be investigated in only partly purified systems. One of our prime interests, for instance, is the question which features determine the in vitro enzyme/substrate recognition. The importance of this question is demonstrated by the fact that the partly purified microsomal system may probably be required for the carboxylation of human blood coagulation factor precursors (notably precursors of factor IX), which are produced via recombinant DNA techniques. During the last few years these techniques have been employed to produce factor IX-like material in prokaryotic (5) and eukaryotic cells $(19,20)$. The products obtained were at best partly carboxylated. Knowledge obtained about the structural requirements of protein substrates for their in vitro carboxylation may therefore be applied for the improvement of this alternative production method of biologically active factor IX.

In this paper we provide an experimental model system in which the enzyme/substrate interaction can be tested. In our experiments we made use of the remarkable observation, that decarboxylated osteocalcin from bovine bone may serve as a substrate for bovine liver carboxylase (13). In contrast, decarboxylated osteocalcins from monkey or human bones were extremely poor substrates in the same system. This phenomenon is not related to species specificity, since similar results were obtained in human liver carboxylase.

With the aid of our model system we have clearly shown that in the case of decarboxylated osteocalcin the presence of two amino acids of opposite charge at a position approximately 15 residues before the first carboxylatable Gluresidue makes that the substrate is readily carboxylated. It is highly suggestive, therefore, that amino acid residues of opposite charge also occur in the prosegments of bovine and human factor X (21), human factor IX (4), bovine and human protein C (22) and human factor VII (23).

It will be clear that, before definite conclusions may be drawn, the model presented here should be tested with more decarboxylated osteocalcins of slightly different structure and it is promising that the amino acid sequence of at least 14 of them has presently been resolved. Also proteolysis or chemical modification of known decarboxylated osteocalcins may give us additional 
information about the structural requirements for a polypeptide chain to be efficiently recognized by vitamin K-dependent carboxylase. Research concerning this point is in current progress in our laboratory.

\section{ACKNOWLEDGEMENTS}

This research was supported by grant C84.463 from the Nier Stichting Nederland, grant 1330-52 from the Division for Health Research TNO and grant 28-1150.7 from the Praeventiefonds. The authors whish to thank Dr. T.C. van Schie for supplying us with monkey bones and Mrs. M. Molenaar-van de Voort for typing this manuscript.

\section{REFERENCES}

1. Meyer, D.I. and Dobberstein, B. J. Cell. Biol. 87: 503-508, 1980

2. Blobel, G. Methods Enzymol. 96: 663-682, 1983

3. Friezner Degen, S.J., MacGillivray, R.T.A. and Davie, E.W. Biochemistry 22: 2087 2097,1983

4. Kurachi, K. and Davie, E.W. Proc. Natl. Acad. Sci. USA 79: 6461-6464, 1982

5. MacGillivray, R.T.A. and Davie, E.W. Biochemistry 23: 1626-1634, 1984

6. Soute, B.A.M., Vermeer, C., de Metz, M., Hemker, H.C. and Lijnen, H.R. Biochim. Biophys. Acta 676: 101-107, 1981

7. De Boer-van den Berg, M.A.G., Ulrich, M.M.W., Hemker, H.C., Soute, B.A.M. and Vermeer, C. Biochim. Biophys. Acta 831: 94-98, 1985

8. Hauschka, P.V., Lian, J.B. and Gallop, P.M. Proc. Natl. Acad. Sci. USA 72: 39253929,1975

9. Price, P.A., Otsuka, A.S., Poser, J.W., Kristaponis, J. and Raman, N. Proc. Natl. Acad. Sci. USA 73: 1447-1451, 1976

10. Hauschka, P.V. and Carr, S.A. Biochemistry 21: 2538-2547, 1982

11. Pan, L.C., Williamson, M.K. and Price, P.A. J. Biol. Chem. 260: 13398-13401, 1985

12. Pan, L.C. and Price, P.A. Proc. Natl. Acad. Sci. USA 82: 6109-6113, 1985

13. Vermeer, C., Soute, B.A.M., Hendrix, H., and de Boer-van den Berg, M.A.G. FEBS Lett. 165: 16-20, 1984

14. Ulrich, M.M.W., Soute, B.A.M., de Boer- van den Berg, M.A.G. and Vermeer, C. Biochim. Biophys. Acta 830: 105-108, 1985

15. Lowry, O.H., Rosebrough, N.J., Farr, A.L. and Randall, R.J. J. Biol. Chem. 137: 265275,1951

16. Kuwada, M. and Katayama, K. Anal. Biochem. 131: 173-179, 1983

17. Weiner, A.M., Platt, T. and Weber, K. J. Biol. Chem. 247: 3242-3251, 1972

18. Esmon, C.T., Sadowski, J.A. and Suttie, J.W. J. Biol. Chem. 250: 4744-4748, 1975

19. De la Salle, H., Altenburger, W., Elkaim, R., Dott, K., Dieterlé, A., Drillieu, R., Cazenave, J.P., Tolstoshev, P. and Lecocq, J.P. Nature 316: 268-270, 1985

20. Busby, S., Kumar, A., Joseph, M., Halfpap, L., Insley, M., Berkner, K., Kurachi, K. and Woodbury, R. Nature 316: 271-273, 1985

21. Fung, M.F., Hay, C.W. and MacGillivray, R.T.A. Proc. Natl. Acad. Sci. USA 82: 3591-3595, 1985

22. Foster, D.C. Yoshitake, S. and Davie, E.W. Proc. Natl. Acad. Sci. USA 82: 4673-4677, 1985

23. Hagen, F.S., Gray, C.L., O'Hara, P., Grant, F.J., Saari, G.C., Woodbury, R.G., Hart, C.E., Insley, M., Kisiel, W., Kurachi, K. and Davie, E.W. Proc. Natl. Acad. Sci. USA 83: 2412-2416, 1986 


\section{ISOLATION AND PARTIAL CHARACTERIZATION OF A VITAMIN K-DEPENDENT CARBOXYLASE FROM BOVINE AORTAE}

L. Johan M. van Haarlem, Magda M.W. Ulrich, H. Coenraad Hemker, Berry A.M. Soute and Cees Vermeer

\section{SUMMARY}

Vitamin K-dependent carboxylase activity has been demonstrated in the crude microsomal fraction of the intima of bovine aortae. The procedure for the isolation of vessel wall carboxylase is a slight modification of the general preparation procedure for tissue microsomes. The highest activity of the nonhepatic enzyme was observed at $25 \mathrm{\circ C}^{\circ}$ and hardly any NADH-dependent vitamin $\mathrm{K}$ reductase could be demonstrated. The optimal reaction conditions for both vessel wall and liver carboxylase were similar: $0.1 \mathrm{M} \mathrm{NaCl}, 0.05 \mathrm{M}$ Tris- $\mathrm{HCl}$, $\mathrm{pH} 7.4$, containing $8 \mathrm{mM}$ DTT, $0.4 \%$ CHAPS (w/v), $0.4 \mathrm{mM}$ vitamin $\mathrm{K}$ hydroquinone and $2 \mathrm{M}\left(\mathrm{NH}_{4}\right)_{2} \mathrm{SO}_{4}$. Warfarin inhibits the hepatic and non-hepatic carboxylase/reductase enzyme complex more or less to a similar degree. We have measured the apparent $K_{m}$ values for the following substrates: Phe-Leu-Glu-Glu-Leu (F L E E L), d-osteocalcin, d-fragment 1329 from descarboxyprothrombin and d-sperm 4-carboxyglutamic acid-containing (Gla-)protein. The results obtained demonstrate that liver and vessel wall carboxylase may be regarded as isoenzymes with different substrate 
specificities. The newly discovered enzyme is the first vitamin $\mathrm{K}$-dependent carboxylase which shows an absolute substrate specificity: F L E E L and dosteocalcin were good substrates for vessel wall carboxylase, but d-fragment 13-29 and d-sperm Gla-protein were not carboxylated at all.

\section{INTRODUCTION}

Vitamin K-dependent carboxylase is a microsomal enzyme system, discovered in rat liver more than 10 years ago (1). Since then, carboxylase activity has been demonstrated in the livers of a wide variety of species, including man (2-4). The enzyme is involved in the post-translational carboxylation of distinct glutamic acid (Glu) residues into 4-carboxyglutamic acid (Gla) residues $(5,6)$. For many years it has been thought that the carboxylating enzyme system was only restricted to the liver, but recently carboxylase has also been detected in other tissues such as lung, kidney, spleen, testis and bone $(7,8)$. Whereas it is known that hepatic carboxylase is involved in the production of a number of proteins involved in blood coagulation, the importance of the non-hepatic systems is far less understood.

In the liver three metabolites of vitamin $\mathrm{K}$ have been identified: vitamin $\mathrm{K}$ quinone $(\mathrm{K})$, vitamin $\mathrm{K}$ hydroquinone $\left(\mathrm{KH}_{2}\right)$ and vitamin $\mathrm{K}$ epoxide $(\mathrm{KO})$. Of these three metabolites $\mathrm{KH}_{2}$ is the coenzyme for carboxylase and its oxidation to KO probably provides the energy required for the carboxylation reaction. $\mathrm{KO}$ is then reduced to $\mathrm{K}$ and $\mathrm{KH}_{2}$ by two or more reductases. In this way there is a cyclic interconversion of vitamin $\mathrm{K}$ metabolites resulting in a constant supply of $\mathrm{KH}_{2}$, so that the coenzyme can be re-used many times. DTT may serve in vitro as a reducing cofactor for these reductases, but the physiological cofactor has not yet been identified (9). Like the carboxylase, also the reductases are found in the microsomal fraction of tissue homogenates, where they seem to occur closely associated with carboxylase.

In this paper we describe the isolation and partial characterization of a nonhepatic vitamin $\mathrm{K}$-dependent carboxylase present in the microsomal fractions of the intima of bovine aortae. Unfortunately the reaction product of this vessel wall carboxylase has not yet been identified. It might be related to the Gla-containing protein found in hardened atherosclerotic plaque $(10,11)$. Since a number of non-hepatic Gla-containing proteins are found in calcified tissues $(12,13)$, it might be possible that the product of vessel wall carboxylase plays a role in the deposition of calcium salts in the vessel wall during atherosclerosis. 


\section{MATERIALS AND METHODS}

\section{Chemicals}

Vitamin $\mathrm{K}_{1}$ (Konakion) was obtained from Hoffmann-La Roche (Basel, Switzerland) and chemically reduced into the hydroquinone form (3). Warfarin, dithiothreitol, CHAPS and Triton X-100 were purchased from Sigma (St. Louis, U.S.A.), and the synthetic substrate Phe-Leu-Glu-Glu-Leu (F L E E L) was from Vega Biochemicals (Tucson, U.S.A.). Sucrose was obtained from BDH (La Poole, U.K.). $\mathrm{NaH}^{14} \mathrm{CO}_{3}(40-60 \mathrm{Ci} / \mathrm{mol})$ was from Amersham International (U.K.) and Atomlight from New England Nuclear (Dreieich, F.R.G.). CNBr-activated Sepharose, QAE-Sephadex and Sephadex G-25 were purchased from Pharmacia (Uppsala, Sweden). The proteinase subtilisin and NADH were obtained from Boehringer (Mannheim, F.R.G.). All other chemicals were from Merck (Darmstadt, F.R.G.).

\section{Preparation of microsomal liver carboxylase}

Crude microsomes were prepared from the liver of normal cows as described earlier (3). The microsomes obtained were suspended in buffer A (0.5 M NaCl, 0.05 M Tris-HCl, pH 7.4, $1 \mathrm{mM}$ EDTA, $20 \%$ (v/v) ethylene glycol) to a final protein concentration of $10 \mathrm{mg} / \mathrm{ml}$. The preparations were kept at -80 o $\mathrm{C}$ until use.

\section{Preparation of vessel wall carboxylase}

Bovine aortae were obtained from normal cows within $1 \mathrm{~h}$ after slaughter and were quickly cooled in ice-cold buffer $\mathrm{B}(0.25 \mathrm{M}$ sucrose, $0.1 \mathrm{M} \mathrm{NaCl}$, $0.05 \mathrm{M}$ Tris- $\mathrm{HCl}, \mathrm{pH} \mathrm{7.4,20 \%}$ (v/v) ethylene glycol). The aortae were prepared free from media and adventitia and subsequently homogenized in buffer B using a high-speed homogenizer (Breda Scientific). A 20\% homogenate $(w / v)$ was used for the preparation of the crude microsomal fraction (3). It was observed that during the centrifugation at $10000 \mathrm{xg}$ of the homogenate at $4{ }^{\circ} \mathrm{C}$, the carboxylating enzyme was coprecipitated with collagen, resulting in a hardly detectable carboxylase activity in the microsomal fraction. Elevation of the temperature to $20{ }^{\circ} \mathrm{C}$ during the centrifugation at $10000 \times \mathrm{g}$ could solve this problem. After one wash the 
obtained microsomal fraction was suspended in buffer $\mathrm{A}$ to a concentration of $10 \mathrm{mg}$ of protein/ml, frozen in liquid nitrogen and stored at $-80{ }^{\circ} \mathrm{C}$ until use.

\section{Measurement of carboxylase activity}

Unless stated otherwise, the vitamin $\mathrm{K}$-dependent incorporation of ${ }^{14} \mathrm{CO}_{2}$ was measured by incubating reaction mixtures $(0.25 \mathrm{ml})$ in buffer A containing: $1.0 \mathrm{mg}$ of microsomal protein and $0.01 \mathrm{mCi}$ of $\mathrm{NaH}^{14} \mathrm{CO}_{3}$. The concentrations of exogenous substrates were as indicated. The optimal reaction conditions for the two enzymes were similar: $0.1 \mathrm{M} \mathrm{NaCl}, 0.05 \mathrm{M}$ Tris- $\mathrm{HCl}$, $\mathrm{pH} 7.4$, containing $8 \mathrm{mM}$ DTT, $0.4 \%$ CHAPS (w/v), $2 \mathrm{M}\left(\mathrm{NH}_{4}\right)_{2} \mathrm{SO}_{4}$ and 0.4 $\mathrm{mM}$ vitamin $\mathrm{K}$ hydroquinone, which was the last compound added to the reaction mixture. After sealing the tubes the mixtures were incubated at $25{ }^{\circ} \mathrm{C}$ and at the indicated times the reaction was stopped by adding $2 \mathrm{ml}$ of $5 \%(\mathrm{w} / \mathrm{v})$ trichloroacetic acid. Subsequently traces of non-bound label were removed by degassing the samples at elevated temperatures for 3 minutes, before $10 \mathrm{ml}$ of Atomlight was added. The samples were counted in a Beckman LS 1801 scintillation counter.

\section{Preparation of substrates}

Osteocalcin was prepared from bovine bone and partly purified by batchwise adsorption to QAE-Sephadex in $0.15 \mathrm{M} \mathrm{NaCl}, 0.02 \mathrm{M}$ Tris-HCl, $\mathrm{pH} 7.4$, followed by a stepwise elution with $1 \mathrm{M} \mathrm{NaCl}$, desalting, thermal decarboxylation and purification by preparative high-performance liquid chromatography (14). Decarboxylated sperm Gla-protein (from human sperm) was prepared as described earlier (15). Descarboxyprothrombin fragment 13-29 was prepared by the proteolytic cleavage of purified bovine descarboxyprothrombin with subtilisin and purified with the aid of ion-exchange and sizeexclusion chromatography (16).

\section{Determination of apparent $K_{m}$ values}

The reaction mixtures, containing various substrate concentrations, were incubated for different time intervals. For the determination of the kinetic constants, the period was chosen during which the reaction rates were linear. The data obtained in the absence of substrates were subtracted from those obtained in the presence of the substrate. The inverse of the initial reaction rates thus obtained was plotted against the inverse substrate concentrations. 
From the resulting Lineweaver-Burk plot, the apparent Michaelis constant $\left(K_{m}\right)$ was calculated according to the method of Eisenthal and Cornish-Bowden (17).

\section{Other methods}

Protein concentrations were determined as described by Sedmak and Grossberg (18). Decarboxylation of Gla-containing proteins was performed according to Poser and Price (19).

\section{RESULTS}

Once having succeeded in preparing in a reproducible way an active microsomal fraction from vessel wall, we wanted to characterize this vitamin K-dependent carboxylating enzyme system.

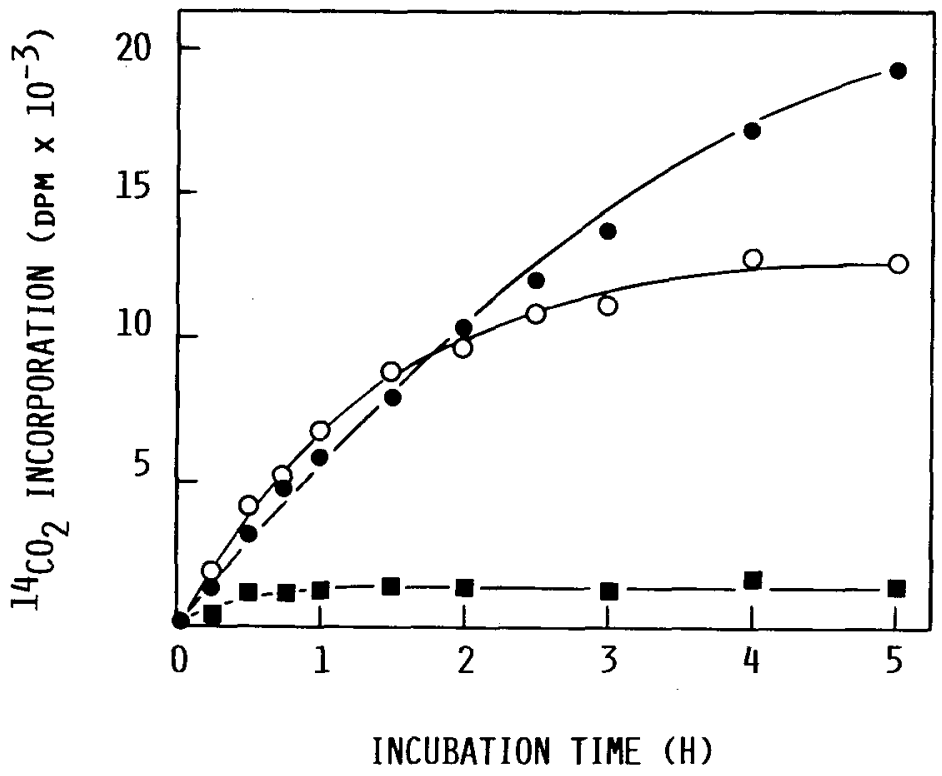

Fig. 1. Effect of temperature upon vessel wall carboxylase activity during time-course studies.

The incorporation of ${ }^{14} \mathrm{CO}_{2}$ was measured as described in the Materials and methods section in the presence of $8 \mathrm{mM} \mathrm{F} \mathrm{LE} \mathrm{E} \mathrm{L} \mathrm{after} \mathrm{various} \mathrm{incubation} \mathrm{times} \mathrm{at}$ $25^{\circ} \mathrm{C}(\mathbf{O}-0), 30^{\circ} \mathrm{C}(\mathrm{O}-\mathrm{O})$ and $37^{\circ} \mathrm{C}(\mathbf{m}-\mathbf{a})$. 
In the first place we determined the optimal reaction conditons. These were similar for the hepatic and non-hepatic carboxylase (see the Materials and methods section).The carboxylase can be extracted from the crude microsomes of bovine aortae with the aid of detergents. The zwitterionic detergent CHAPS appeared to be a better detergent than the non-ionic Triton X-100 (results not shown). These findings are in agreement with the data obtained from earlier studies performed with liver carboxylase (20).

The carboxylating enzyme system from the vessel wall shows the highest activity at $25^{\circ} \mathrm{C}$ and at this temperature the reaction rate was constant for $2 \mathrm{~h}$ (fig. 1). On the other hand, carboxylase activity was hardly measurable at 37 ${ }^{\circ} \mathrm{C}$, which indicates that in vitro the enzyme is quickly destroyed at this temperature. Because of these results all experiments described below were performed at $25^{\circ} \mathrm{C}$ using an incubation time of $2 \mathrm{~h}$.

In the next experiments we have compared the carboxylating enzyme system from the vessel wall with that from the liver. Besides vitamin $\mathrm{K}$ hydroquinone, also vitamin $\mathrm{K}$ quinone could be used as a coenzyme for carboxylase from both types of tissue (results not shown). This demonstrates that, like the liver enzyme, also vessel wall carboxylase is associated with a reducing enzyme system. Dithiols such as DTT proved to be the most effective cofactor in vitro for these reductases. Since it is well known that in liver the DTT-dependent reductase is the site of action of vitamin $K$ antagonists like warfarin, we have compared the sensitivity for this drug of the carboxylase/reductase enzyme systems from liver and vessel wall, using vitamin $\mathrm{K}$ quinone as a coenzyme. As shown in fig. 2, both systems are, at least in vitro, inhibited to a similar degree.

We have also tried to detect the NADH-dependent vitamin $\mathrm{K}$ reductase in the vessel wall preparation, since its presence in a number of tissues has been reported (9). In these experiments again we used vitamin $\mathrm{K}$ quinone instead of the hydroquinone and DTT was replaced by NADH $(2 \mathrm{mM})$. It turned out that under the assay conditions used here the NADH-mediated carboxylation was low relative to the dithiol-supported reaction, both in hepatic as well as in nonhepatic microsomes (less than 5\%). Although we had not been able to detect differences between the vitamin K-binding sites of the two types of enzyme, it might still be possible that differences might be found at the substrate-binding sites. We have investigated this possibility by measuring the apparent kinetic constants of substrates of various origins in hepatic and non-hepatic microsomal fractions. Although we are aware of the complication that both, liver as well as vessel wall, carboxylases have not been purified completely, sufficient information can be obtained from these system when the appropriate 


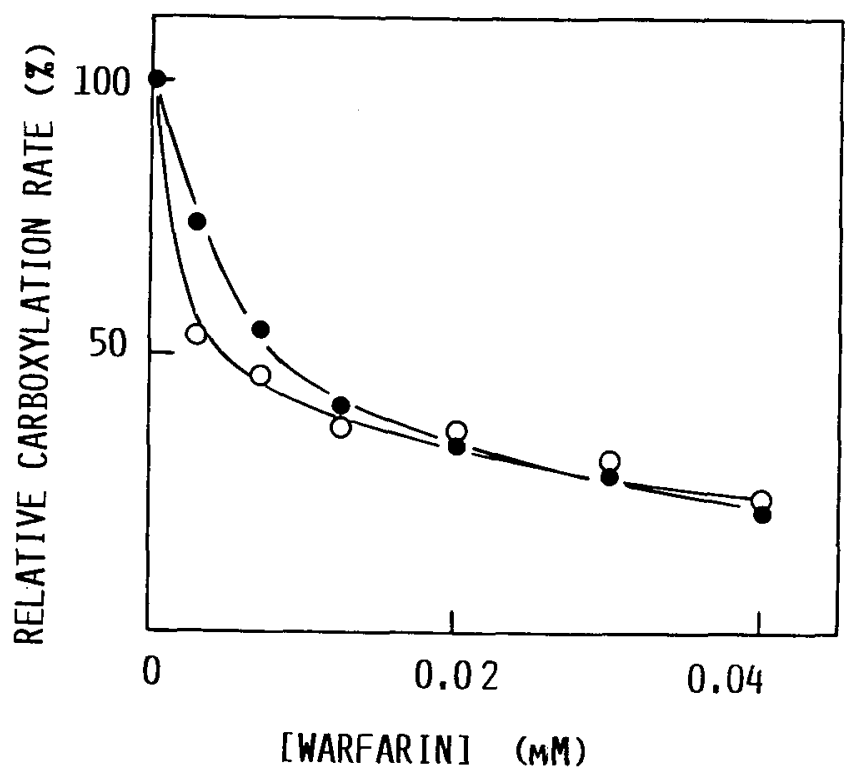

Fig. 2. Effect of warfarin on carboxylase/reductase from liver (--O) and vessel wall $(O-O)$.

The inhibition by warfarin of the enzyme systems was measured by performing the carboxylation reaction under standard conditions (see the Materials and methods section) except that vitamin $\mathrm{KH}_{2}$ was replaced by $0.4 \mathrm{mM}$ vitamin $\mathrm{K}$. F L E E L $(8 \mathrm{mM})$ was used as an exogenous substrate and warfarin (in the form of its sodium salt) was mixed with vitamin $\mathrm{K}$ before it was added to the reaction mixture. The $100 \%$ enzyme activity values were $1054 \mathrm{dpm} / \mathrm{min}$ per $\mathrm{mg}$ of microsomal protein for liver carboxylase and $110 \mathrm{dpm} / \mathrm{min}$ per $\mathrm{mg}$ of microsomal protein for vessel wall carboxylase.

controls are made. For the determination of the kinetic constants, the reaction mixtures were incubated for $60 \mathrm{~min}$. During this period the reaction rates were linear. The data obtained in the absence of vitamin $\mathrm{K}$ hydroquinone were subtracted from those obtained in the presence of vitamin $\mathrm{K}$ hydroquinone. The data obtained in the absence of substrates were subtracted from those obtained in the presence of the substrate. The following carboxylatable substrates were available: the pentapeptide F L E E L, decarboxylated osteocalcin (from bovine bone), decarboxylated fragment 13-29 (which is composed of the amino acid residues 13-29 in bovine descarboxyprothrombin) and decarboxylated sperm Gla-protein (from human sperm). The apparent $K_{m}$ values for these four substrates were measured in the two carboxylating 
enzyme systems and the results of these experiments are summarized in table I. It is evident that d-osteocalcin is a good substrate for liver carboxylase and to a lesser degree also for vessel wall carboxylase. The apparent $K_{m}$ values for both substrates are much lower than those observed for the pentapeptide, which are in the millimolar range. It was not possible to measure the apparent $K_{m}$ values for fragment 13-29 and for d-sperm Gla-protein in vessel wall carboxylase, since even at high concentrations these substrates were carboxylated to a negligible degree.

TABLE I

Kinetic constants of various substrates for liver and vessel wall carboxylase

\begin{tabular}{lcc}
\hline \multicolumn{1}{c}{ Substrate } & \multicolumn{2}{c}{ Apparent $K_{m}(\mu \mathrm{M})$} \\
\cline { 2 - 3 } & Liver & Vessel wall \\
\hline Phe-Leu-Glu-Glu-Leu & 1600 & 2300 \\
d-Osteocalcin & 0.4 & 1.8 \\
d-Fragment 13-29 & 6 & n.m. \\
d-Sperm Gla-protein & 96 & n.m. \\
\hline
\end{tabular}

The apparent $K_{m}$ values were calculated from the initial carboxylation rates at various substrate concentrations (see the Material and methods section). The concentrations of the substrates employed in these experiments ranged from 1 to $8 \mathrm{mM}$ for F L E E L, from 0.24 to $2.4 \mu \mathrm{M}$ for d-osteocalcin, from 1.3 to $9.3 \mu \mathrm{M}$ for d-fragment 13 to 29 and from 28 to $116 \mu \mathrm{M}$ for d-sperm Gla-protein. N.m., not measurable.

It must be pointed out, however, that these studies were performed with equal amounts of microsomal proteins. Since the enzyme activity per mg of protein is higher in microsomes from liver than in those from vessel wall, dissimilar amounts of carboxylase activity were used. We also performed a control experiment in which we measured the carboxylation of d-sperm Glaprotein in both systems using similar amounts of carboxylase activity. Using an excess of the pentapeptide F L E E L $(8 \mathrm{mM})$ as a substrate, we determined the relation between the carboxylation rate and the microsomal protein concentration. A linear relationship was found between 0.1 and $4 \mathrm{mg} / \mathrm{ml}$ and it appeared that $0.125 \mathrm{mg}$ of hepatic microsomes contained a similar enzyme activity as $1.0 \mathrm{mg}$ of the vessel wall preparation. Subsequently we compared the carboxylation of d-sperm Gla-protein under the conditions of similar protein concentration (fig. $3 \mathrm{~A}$ ) as well as under those of similar carboxylase 

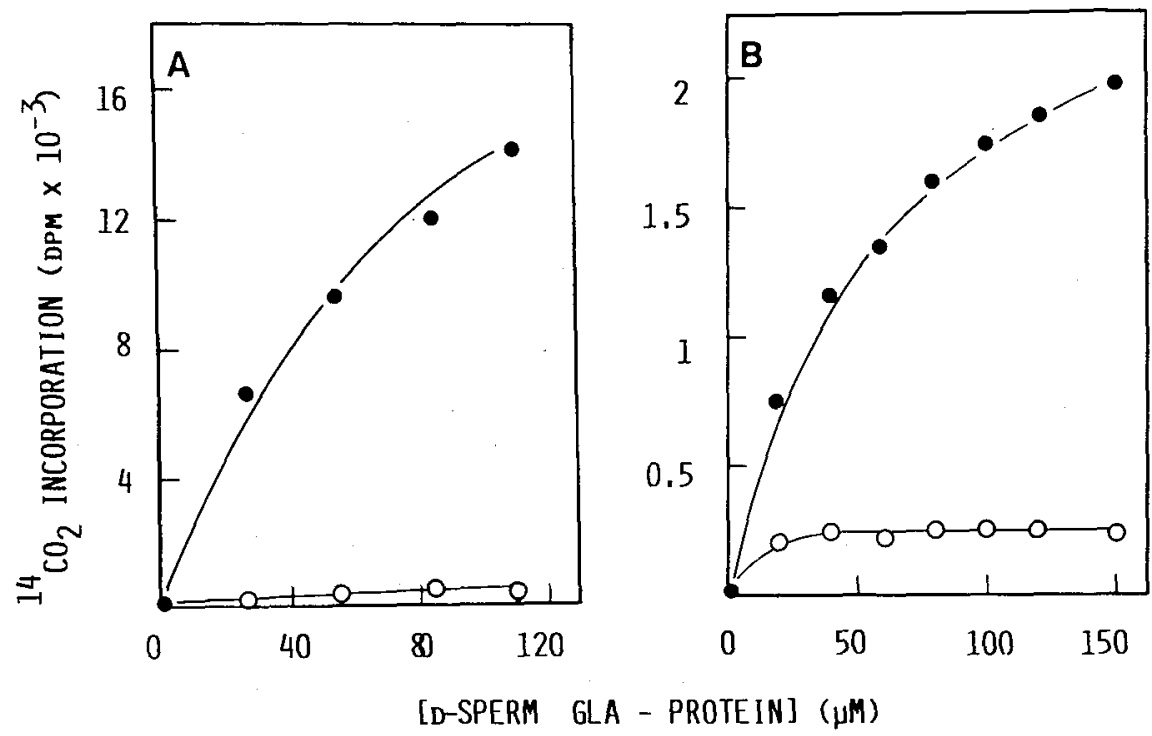

Fig. 3. Carboxylation of d-sperm Gla-protein at various concentrations of microsomal proteins.

A: The carboxylation of d-sperm Gla-protein in the presence of $1 \mathrm{mg}$ of microsomal protein/ml from liver $(0-0)$ and from vessel wall $(\mathrm{O}-\mathrm{O})$.

B: The carboxylation of d-sperm Gla-protein in the presence of similar amounts of peptide carboxylase. The amounts of microsomal proteins added were $0.125 \mathrm{mg}$ (liver) and $1 \mathrm{mg}$ (vessel wall) respectively. It was checked that under these conditions both preparations were able to carboxylate F L E E L at a similar reaction rate.

The incorporation of ${ }^{14} \mathrm{CO}_{2}$ was measured after incubation periods of $60 \mathrm{~min}$. Note the different scales for A and B.

activity (fig. 3B). It turned out that liver carboxylase was the only system to carboxylate d-sperm Gla-protein to a reasonable extent. These results therefore strongly favour the idea that vitamin $\mathrm{K}$-dependent carboxylase is a group name for a series of enzymes, each with a different enzyme specificity and that vessel wall carboxylase is another member of this family.

\section{DISCUSSION}

In a previous study it has been demonstrated that the vitamin K-dependent carboxylases from the liver, kidney, lung and testis may be regarded as a group of isoenzymes, which mainly differ in their substrate specificity (21). In this paper we report the isolation and partial characterization of the vitamin K- 
dependent carboxylase from bovine aortae. The enzyme is, as in other tissues, located in the microsomal fraction of the tissue homogenate. We have investigated whether the non-hepatic enzyme is comparable with hepatic carboxylase or whether also in this case differences might exist between both enzymes.

For the isolation of vessel wall carboxylase the general preparation procedure for tissue microsomes had to be slightly modified. It was found that, during the low-speed centrifugation at $4{ }^{\circ} \mathrm{C}$ of the collagen-rich vessel wall homogenate, carboxylase was co-precipitated with the collagen, resulting in a hardly detectable carboxylase activity in the microsomal fraction. By working quickly at $20^{\circ} \mathrm{C}$ this problem could be solved. The resulting washed microsomes were solubilized and contained vitamin $\mathrm{K}$-dependent carboxylase as well as DTT-dependent reductase.

In a first set of experiments we have compared the liver and vessel wall carboxylase/reductase system with respect to their sensitivity towards warfarin. It turned out that both enzyme systems are inhibited in vitro by the drug to a more or less similar degree. This is in agreement with earlier experiments in vitro with other non-hepatic microsomal preparations $(4,6)$ and with experiments in vivo, in which it was shown that the oral administration of low doses of warfarin to rats induces the accumulation of non-carboxylated precursor proteins in the microsomal fraction of hepatic as well as of nonhepatic tissues (22).

In a second set of experiments we have compared the affinity of the two carboxylating systems towards different substrates. Four substrates were available: the pentapeptide F L E E L, d-osteocalcin, d-fragment 13-29 and d-sperm Gla-protein. It turned out that the latter two substrates were not carboxylated to a significant extent by vessel wall carboxylase. In an earlier report, in which we have compared carboxylase from liver, lung, kidney and testis, we have shown that all substrates were carboxylated by these enzymes, but that the carboxylases had a preference for either d-fragment 13-29 or d-sperm Glaprotein (21). Vessel wall carboxylase is different from the former enzymes, because only F L E E L and d-osteocalcin are carboxylated, whereas the other substrates are not recognized at all.

Unfortunately the reaction product of vessel wall carboxylase has not yet been identified. It might be related to the Gla-containing protein found in hardened atherosclerotic plaque $(10,11)$, but this is still uncertain at the moment. Since many non-hepatic Gla-containing proteins are found in various calcified tissues, the product of vessel wall carboxylase might play a role in the deposition of calcium salts in the vessel wall during atherosclerosis. From our observations it seems likely that the vitamin K-dependent enzyme system from 
vessel wall is similarly sensitive to warfarin as is the liver enzyme and therefore it cannot be excluded that, in patients undergoing oral anticoagulant therapy, which is meant to reduce the degree of carboxylation of their blood coagulation factors, also the products of vessel wall carboxylase are synthesized in an undercarboxylated form. Whether this effect has any clinical relevance remains to be awaited, however.

\section{ACKNOWLEDGEMENTS}

This research was supported by grant 13-30-52 from the Divison for Health Research TNO. The authors wish to thank Mr. P.G.F. van de Loo for his technical assistance and Mrs. M. Molenaar-van de Voort for typing this manuscript.

\section{REFERENCES}

1. Esmon, C.T., Sadowski, J.A. and Suttie, J.W. J. Biol. Chem. 250: 4744-4748, 1975

2. Suttie, J.W., Lehrman, S.R., Geweke, L.O., Hageman, J.M. and Rich, D.H. Biochem. Biophys. Res. Commun. 86: 500-507, 1979

3. Vermeer, C., Soute, B.A.M., De Metz, M. and Hemker, H.C. Biochim. Biophys. Acta 714: 361-365, 1982

4. Soute, B.A.M., De Metz, M. and Vermeer, C. FEBS Lett. 146: 365-368, 1982

5. Suttie, J.W. CRC Crit. Rev. Biochem. 8: 191-223, 1980

6. Vermeer, C. Mol. Cell. Biochem. 61: 17-35, 1984

7. Buchtal, S.D. and Bell, R.G. Biochemistry 22: 1077-1082, 1983

8. Vermeer, C., Hendrix, H. and Daemen, M. FEBS Lett. 148: 317-320, 1982

9. Wallin, R., Gebhardt, O. and Prydz, H. Biochem. J. 69: 95-101, 1978

10. Levy, R.J.. Lian, J.B. and Gallop, P.M. Biochem. Res. Commun. 91: 41-49, 1979

11. Levy, R.J., Howard, S.L. and Oshry, L.J. Atherosclerosis 59: 155-160, 1986

12. Hauschka, P.V., Lian, J.B. and Gallop, P.M. Proc. Nat. Acad. Sci. (USA) 72: 3925 3929,1976

13. Lian, J.B., Prien, E.L., Glimcher, M.J. and Gallop, P.M. J. Clin. Invest. 59: 1151-1157, 1977

14. Vermeer, C., Soute, B.A.M., Hendrix, H. and De Boer-van den Berg, M.A.G. FEBS Lett. 165: 16-20, 1984

15. Soute, B.A.M., Müller-Esterl, W., De Boer-van den Berg, M.A.G., Ulrich, M.M.W. and Vermeer, C. FEBS Lett. 190: 137-141, 1985

16. Soute, B.A.M., Vermeer, C., De Metz, M., Hemker, H.C. and Lijnen, H.R. Biochim. Biophys. Acta 676: 202-207, 1981

17. Eisenthal, R. and Cornish-Bowden, A. Biochem. J. 139: 715-729, 1974

18. Sedmak, J.J. and Grossberg, S.E. Anal. Biochem. 79: 544-552, 1977

19. Poser, J.W. and Price, P.A. J. Biol. Chem. 254: 431-436, 1979

20. Girardot, J.M. and Johnson, B.C. Anal. Biochem. 121: 315-320, 1982

21. Ulrich, M.M.W., Soute, B.A.M., De Boer-van den Berg, M.A.G. and Vermeer, C. Biochim. Biophys. Acta 830: 105-108, 1985

22. Roncaglioni, M.C., Soute, B.A.M., De Boer-van den Berg, M.A.G. and Vermeer, C. Biochem. Biophys. Res. Commun. 114: 991-997, 1983 
54 
2C

\title{
VITAMIN K-DEPENDENT CARBOXYLASE: POSSIBLE ROLE FOR THIOREDOXIN IN THE REDUCTION OF VITAMIN K-METABOLITES IN LIVER
}

\author{
L. Johan M. van Haarlem, Berry A.M. Soute and Cees Vermeer
}

\section{SUMMARY}

In the liver vitamin $\mathrm{K}$ epoxide, which is produced during the posttranslational carboxylation of protein-bound glutamic acid residues, is recycled by the action of one or more dithiol-dependent reductases. In vitro synthetic dithiols may serve as a cofactor for these enzymes, but the physiological reductant has not yet been found. In this paper we report that in vitro the commercially available thioredoxin/thioredoxin reductase from E.coli can replace the synthetic dithiols during the various reactions of the vitamin $\mathrm{K}$ cycle. Based on the assumption that in vivo thioredoxin also plays a role in the regeneration of vitamin $\mathrm{K}$ hydroquinone from the epoxide, an extension of the generally accepted vitamin $\mathrm{K}$ cycle is proposed.

\section{INTRODUCTION}

Vitamin K-dependent carboxylase is a microsomal enzyme system involved in the formation of 4-carboxyglutamic acid (Gla) residues (1-3). The energy required for the carboxylation reaction is generated by the simultaneous oxidation of the coenzyme vitamin $\mathrm{K}$ hydroquinone $\left(\mathrm{KH}_{2}\right)$ into vitamin $\mathrm{K}$ epoxide (KO). The epoxide may then be recycled again to the hydroquinone by one or 
more reductases, possibly via vitamin $\mathrm{K}$ quinone $(\mathrm{K})$ as an intermediate. In the literature much confusion exists about the number and the nature of the reducing enzyme system(s). Dithiol-dependent enzymes have been described which convert $\mathrm{KO}$ to $\mathrm{K}(4,5)$ and $\mathrm{K}$ to $\mathrm{KH}_{2}(6,7)$ and the question of whether these two activities are carried out by the same enzyme has not yet been answered satisfactorily. Also, a NADH- or NADPH-dependent reductase has been reported, which is able to generate $\mathrm{KH}_{2}$ from $\mathrm{K}$ but which cannot recycle KO $(8,9)$. It has been suggested $(10)$ that the latter enzyme may be similar to the cytosolic DT-diaphorase (EC 1.6.99.2). In contrast to the dithiol-dependent reductases, the $\mathrm{NAD}(\mathrm{P}) \mathrm{H}$-dependent enzyme seems to be insensitive to vitamin $\mathrm{K}$ antagonists of the dicoumarol type (warfarin, acenocoumarol, phenprocoumon). The concentration of $\mathrm{NAD}(\mathrm{P}) \mathrm{H}$-dependent reductase in washed microsomes is relatively low, however. Two conclusions may be drawn from the data reported until now: 1) dithiols like dithiothreitol are much better cofactors for the in vitro reductase(s) than $\mathrm{NAD}(\mathrm{P}) \mathrm{H}$ and 2) the physiological counterpart of these dithiols has not yet been identified. Thioredoxin is a protein which has been described as acting as a dithiol in many biochemical reactions and occurs in organisms differing as much as E.coli and mammals $(11,12)$. Also, in calf liver its presence has been established (13). In its oxidized form the protein requires an enzyme named thioredoxin reductase (EC 1.6.45) and NADPH to be converted into its reduced form. In this way thioredoxin may be efficiently recycled in vivo. We have tested whether the commercially available thioredoxin/thioredoxin reductase system from E.coli would be able to replace dithiothreitol in the carboxylase/reductase enzyme system from bovine liver. The results of these experiments are presented here.

\section{MATERIALS AND METHODS}

\section{Chemicals}

Vitamin $\mathrm{K}_{1}$, warfarin, dithiothreitol and CHAPS were obtained from Sigma (St. Louis, U.S.A.) and the synthetic pentapeptide Phe-Leu-Glu-Glu-Leu (F L E E L) from Vega Biochemical (Tucson, U.S.A.). Vitamin $\mathrm{K}_{1}$ epoxide was prepared as in (14). Thioredoxin and thioredoxin reductase were purchased from IMCO (Stockholm, Sweden) and $\mathrm{NaH}^{14} \mathrm{CO}_{3}(40 \mathrm{Ci} / \mathrm{mol})$ from Amersham International (U.K.). Atomlight was from New England Nuclear (Dreieich, F.R.G.) and NADPH from Boehringer (Mannheim, F.R.G.). All other chemicals were of the highest purity commercially available. 


\section{Carboxylase assay}

Salt-washed microsomes and partly purified carboxylase were prepared from the livers of normal cows (15). Unless indicated otherwise, the vitamin $\mathrm{K}$-dependent incorporation of ${ }^{14} \mathrm{CO}_{2}$ was measured in reaction mixtures $(0.125 \mathrm{ml})$ containing $0.3 \mathrm{mg}$ of partly purified carboxylase, $0.15 \mathrm{M} \mathrm{NaCl}$, $1 \mathrm{M}\left(\mathrm{NH}_{4}\right)_{2} \mathrm{SO}_{4}, 20 \mathrm{mM}$ Tris- $\mathrm{HCl}$, pH 7.5, $8 \mathrm{mM} \mathrm{MnCl}_{2}, 5 \mathrm{Ci} \mathrm{NaH}{ }^{14} \mathrm{CO}_{3}$, $4 \mathrm{mM}$ F L E E L, $0.16 \%$ (w/v) CHAPS, $0.4 \mathrm{mg} / \mathrm{ml}$ phosphatidylcholine (added as mixed micelles with cholate in a $1: 1(\mathrm{w} / \mathrm{w})$ ratio) and $0.4 \mathrm{mM}$ of either vitamin $\mathrm{K}$ quinone or vitamin $\mathrm{K}$ epoxide. The vitamin was solubilized by mixing it with the phosphatidylcholine before preparing the mixed micelles according to De Metz et al. (16). Dithiothreitol, NADPH, thioredoxin and thioredoxin reductase were added as indicated. The reaction mixtures were incubated at $25{ }^{\circ} \mathrm{C}$ and the reaction was stopped by adding $1 \mathrm{ml}$ of $5 \%(\mathrm{w} / \mathrm{v})$ trichloroacetic acid. The samples were subsequently boiled for $1 \mathrm{~min}$ and counted in Atomlight. All measurements were made in duplicate and mean values are given throughout this paper.

\section{Other assays}

Protein concentrations were determined as described by Sedmak and Grossberg (17).

\section{RESULTS}

The three reactions which give rise to the "vitamin $\mathrm{K}$ cycle" are depicted in fig. 1 . The formation of Gla residues occurs in reaction 1 by the enzyme carboxylase, which utilizes vitamin $\mathrm{K}$ hydroquinone $\left(\mathrm{KH}_{2}\right)$ as a coenzyme. The progress of the reaction may be measured by the incorporation of ${ }^{14} \mathrm{CO}_{2}$ into a suitable substrate. Reactions $3+1$ may be measured by starting the same carboxylase assay with vitamin $\mathrm{K}$ quinone $(\mathrm{K})$ instead of $\mathrm{KH}_{2}$. The reduction of $\mathrm{K}$ into $\mathrm{KH}_{2}$, which precedes the carboxylation reaction, is accomplished by $\mathrm{K}$ reductase. Either dithiols (e.g. dithiothreitol) or NAD(P)H may be used as a reducing cofactor, but it was found that at saturating concentrations $(5 \mathrm{mM})$ dithiothreitol is about 20 -fold more effective than NADPH. The NADPHdriven reaction reaches a plateau level at about $2 \mathrm{mM} \mathrm{NADPH}$ and the apparent $K_{m}$ for this cofactor was calculated to be $0.5 \mathrm{mM}$. All experiments 


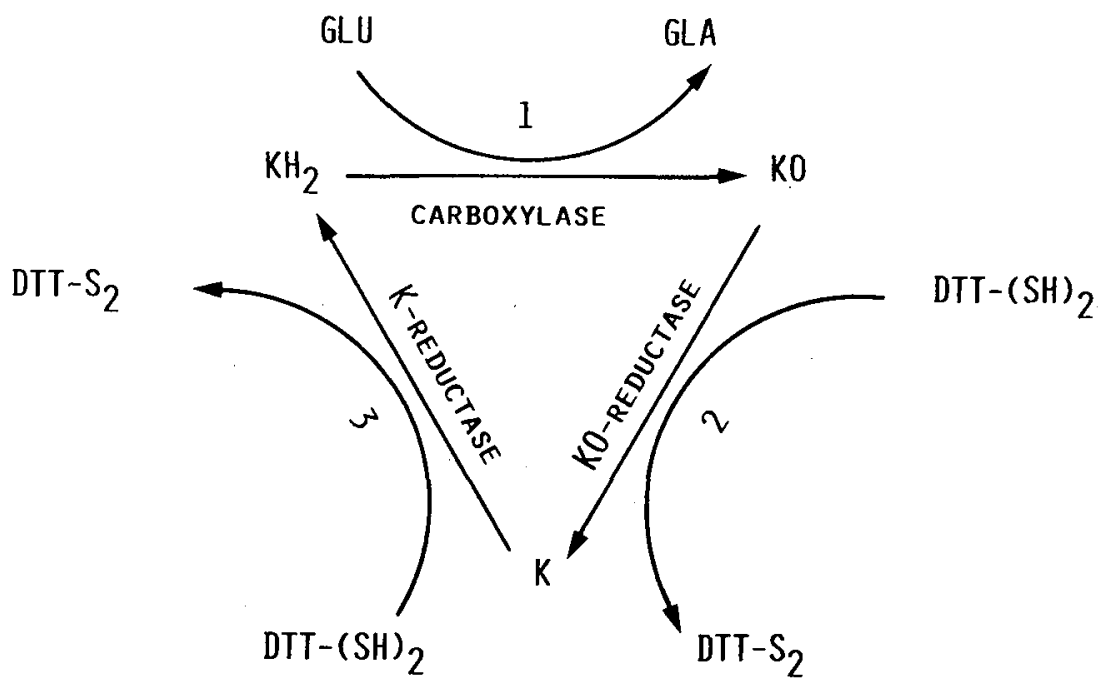

Fig. 1. The vitamin $K$ cycle.

It is generally assumed that vitamin $K$ is recycled in the liver by the action of three enzymes: carboxylase, $\mathrm{KO}$ reductase and $\mathrm{K}$ reductase. It is not certain whether the two reducing steps are accomplished by one or by two enzymes.

described below were performed in the absence of dithiothreitol, but in the presence of an excess of NADPH, i.e. 20 times the $K_{m}$ value $(10 \mathrm{mM})$.

Since NADPH alone seems to be a poor cofactor for vitamin $\mathrm{K}$ reductase, we have tried to stimulate reactions $1+3$ by adding the dithiol protein thioredoxin and/or the reducing enzyme system thioredoxin reductase. As shown in fig. 2 the two proteins alone have no effect on the carboxylase activity, but the combination of the two proteins resulted in a 7 -fold stimulation of the NADPH-driven carboxylation reaction. The results shown in this figure were obtained with partly purified carboxylase, but similar data were observed if salt-washed solubilized microsomes were used as a source of carboxylase (data not shown). Under our experimental conditions saturating concentrations of thioredoxin reductase were reached at $0.6 \mu \mathrm{M}$ (fig. $2 \mathrm{~A}$ ) and all experiments described below were performed therefore at $1 \mu \mathrm{M}$ thioredoxin reductase. Under these conditions the carboxylase reaction could be stimulated 7 -fold by adding thioredoxin (fig. 2B). From the data shown in fig. 2B we have calculated the apparent $K_{m}$ for thioredoxin, which was $20 \mu \mathrm{M}$. For the rest of our experiments we have worked at a thioredoxin concentration of $150 \mu \mathrm{M}$.

To investigate reactions $1+2+3$ (fig. 1 ) in one system, the carboxylation reaction has to be started with vitamin $\mathrm{K}$ epoxide (KO). We have checked if 


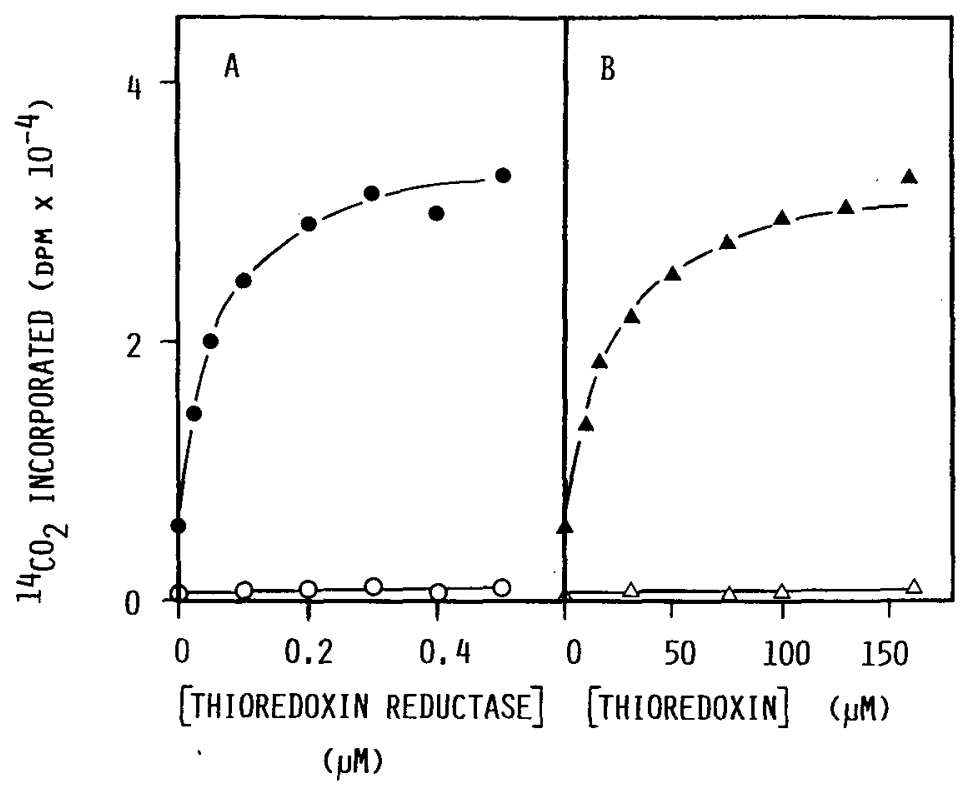

Fig. 2. Effects of thioredoxin reductase and thioredoxin on the carboxylation reaction.

All reaction mixtures contained vitamin $\mathrm{K}$ quinone as a sole source of vitamin $\mathrm{K}$ and were incubated for $1 \mathrm{~h}$ at $25^{\circ} \mathrm{C}$. (A) Increasing amounts of thioredoxin reductase were added to standard reaction mixtures containing $150 \mu \mathrm{M}$ thioredoxin.

(B) Increasing amounts of thioredoxin were added to standard reaction mixtures containing $1 \mu \mathrm{M}$ thioredoxin reductase. All experiments were performed in the presence (closed symbols) and absence (open symbols) of $10 \mathrm{mM} \mathrm{NADPH}$.

the thioredoxin/thioredoxin reductase system could be used as a sole source of reducing cofactor (thioredoxin-( $\mathrm{SH})_{2}$ ) for both vitamin $\mathrm{K}$ reductases. The results of these experiments are summarized in table $\mathrm{I}$ and it is clear that all reactions of the vitamin $\mathrm{K}$ cycle are catalyzed by the thioredoxin/thioredoxin reductase system. Moreover, in the presence of $\mathrm{KO}$ as well as in that of $\mathrm{K}$ the thioredoxin-stimulated reaction rate amounted to about $40 \%$ of that of the DTT-stimulated one.

It is well known that vitamin $\mathrm{K}$ antagonists (warfarin) inhibit the DTTdependent $\mathrm{K}$ and $\mathrm{KO}$ reductases and not the NADH-dependent $\mathrm{K}$ reductase. We have determined to what extent the thioredoxin-dependent $\mathrm{KO}$ and $\mathrm{K}$ reductase activities were inhibited by warfarin. As shown in table II the KO-dependent carboxylation reaction is completely inhibited by $10 \mu \mathrm{M}$ warfarin thus indicating that also with thioredoxin-( $\mathrm{SH})_{2}$ as a cofactor, $\mathrm{KO}$ reductase is inhibited by vitamin $\mathrm{K}$ antagonists. A similar concentration also inhibited the main part of the $\mathrm{K}$-dependent carboxylation reaction, but a residual activity of about $7 \%$ 
TABLE I

Peptide carboxylation in the presence of various cofactors

\begin{tabular}{lc}
\hline Cofactors used & $\begin{array}{c}\text { Initial carboxylation rate } \\
\text { (dpm per min) }\end{array}$ \\
\hline $\mathrm{K}+\mathrm{DTT}$ & 2173 \\
$\mathrm{~K}+\mathrm{NADPH}$ & 106 \\
$\mathrm{~K}+\mathrm{NADPH}+$ thioredoxin & 857 \\
$\mathrm{KO}+\mathrm{DTT}$ & 1601 \\
$\mathrm{KO}+\mathrm{NADPH}$ & 22 \\
$\mathrm{KO}+\mathrm{NADPH}+$ thioredoxin & 645 \\
& \\
\hline In the cases in which thioredoxin-(SH)2 was used, also thioredoxin reductase $(1 \mu \mathrm{M})$ was also \\
present in the reaction mixtures. The initial carboxylation rates were obtained from time-course \\
experiments and were constant for the first 30 min or more. Results are expressed as the \\
amount of 14 CO2 (dpm) incorporated per min under our experimental conditions. Blank values \\
(obtained in the absence of either $\mathrm{K}$ or $\mathrm{KO}$ ) were subtracted.
\end{tabular}

was found, even if the warfarin concentration was raised to $0.1 \mathrm{mM}$. A comparable activity was obtained in the absence of thioredoxin and thioredoxin reductase, so that we must conclude that the warfarin-insensitive activity originates from the NADH-dependent $\mathrm{K}$ reductase, which has been reported earlier to be insensitive for coumarin derivatives (9).

TABLE II

Inhibition of peptide carboxylation by warfarin

\begin{tabular}{lcc}
\hline Cofactors used & $\begin{array}{c}\text { Warfarin concentration } \\
(\mathrm{mM})\end{array}$ & $\begin{array}{c}\text { Initial carboxylation } \\
\text { rate (dpm per min) }\end{array}$ \\
\hline $\mathrm{K}$ & 0 & 203 \\
$\mathrm{~K}+$ thioredoxin & 0 & 1840 \\
$\mathrm{~K}$ & 0.01 & 137 \\
$\mathrm{~K}+$ thioredoxin & 0.01 & 138 \\
$\mathrm{KO}$ & 0 & 13 \\
$\mathrm{KO}+$ thioredoxin & 0 & 1556 \\
$\mathrm{KO}+$ thioredoxin & 0.01 & 0 \\
$\mathrm{KO}+$ the & 9
\end{tabular}

All reaction mixtures contained $10 \mathrm{mM}$ NADPH. In those cases in which thioredoxin was used, thioredoxin reductase $(1 \mu \mathrm{M})$ was also present in the reaction mixtures. Further details as described in the legend to table I. 
In the next set of experiments we have examined whether the thioredoxin/thioredoxin reductase system from E.coli is also an effective system for non-hepatic carboxylases. Salt-washed microsomes were prepared from five different bovine tissues. In these preparations the F L E E L-carboxylation was measured as a function of the concentration of microsomal proteins. As shown in fig. 3 slightly sigmoid curves were obtained. For the enzyme preparations from liver (fig. 3A), lung, spleen and kidney (data not shown) the curves were linear between 0.7 and $3.0 \mathrm{mg} / \mathrm{ml}$, for aorta microsomes (fig. 3B) the linear part of the curve ranged from $0.5-1.2 \mathrm{mg} / \mathrm{ml}$.

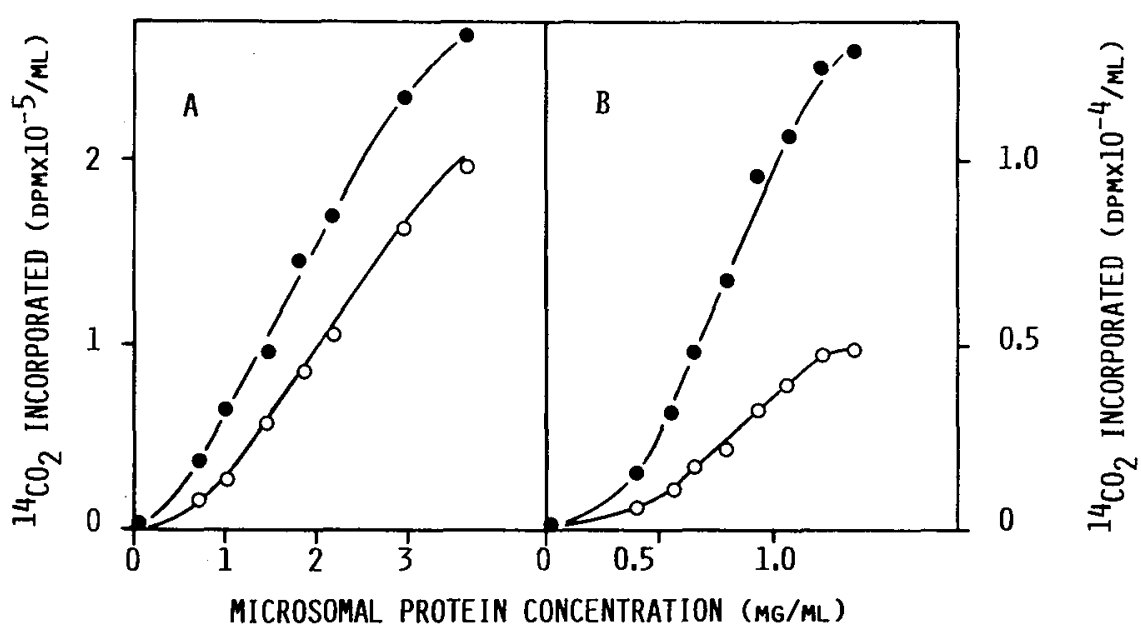

Fig. 3. ${ }^{14} \mathrm{CO}_{2}$ incorporation as a function of the microsomal protein concentration.

Incubations were performed for $60 \mathrm{~min}$ under standard conditions. During this period the carboxylation rate was constant. The reducing cofactors used were either $2 \mathrm{mM}$ DTT (-) or $50 \mu \mathrm{M}$ thioredoxin $+1 \mu \mathrm{M}$ thioredoxin reductase $+2 \mathrm{mM}$ NADPH (O-O).A: carboxylase/reductase complex from liver.B: carboxylase/ reductase complex from aorta.

For the rest of the experiments reported in this paper we have arbitrarily chosen protein concentrations of $2 \mathrm{mg} / \mathrm{ml}$, except for the microsomes from vessel wall, which were used in a concentration of $1.0 \mathrm{mg} / \mathrm{ml}$.

In these systems we have compared the effects of two reducing cofactors: DTT and E.coli thioredoxin. To ensure a constant supply of thioredoxin in its 
TABLE III

Carboxylase/reductase activity in various tissues

\begin{tabular}{lccc}
\hline Origin of & \multicolumn{3}{c}{${ }^{14} \mathrm{CO}_{2}$ incorporation $(\mathrm{dpm} / \mathrm{mg} / \mathrm{min})$} \\
\cline { 3 - 4 } & $\mathrm{K}+\mathrm{DTT}$ & $\mathrm{K}+$ thioredoxin & $\%$ \\
\hline Liver & 2858 & 2080 & 73 \\
Lung & 389 & 200 & 51 \\
Spleen & 287 & 51 & 18 \\
Kidney & 709 & 137 & 19 \\
Aorta & 521 & 166 & 31
\end{tabular}

\begin{abstract}
All samples were tested under standard conditions. The protein concentrations in the reaction mixtures were $2 \mathrm{mg} / \mathrm{ml}$ for liver, lung, spleen, and kidney and $1 \mathrm{mg} / \mathrm{ml}$ for aorta microsomes. If thioredoxin was used, also thioredoxin reductase $(1 \mu \mathrm{M})$ ) and NADPH $(2 \mathrm{mM})$ were supplied to the reaction mixtures. The carboxylase activity is expressed as the amount of ${ }^{14} \mathrm{CO}_{2}$ which is incorporated per mg of microsomal protein and per min. All measurements were performed in the linear phase of the carboxylation reaction. In the last column the values obtained with thioredoxin are expressed as a percentage of the DTT-directed reaction.
\end{abstract}

reduced form, the dithiol protein was always used in the combination with thioredoxin reductase and NADPH. The optimal concentration of DTT was determined for all enzyme systems and plateau levels were reached at $2 \mathrm{mM}$. Saturating concentrations for thioredoxin were found to be two orders of magnitude lower: between 30 and $50 \mu \mathrm{M}$. Hence $50 \mu \mathrm{M}$ thioredoxin was used for the experiment which is summarized in table III. It is clear that the highest carboxylation rates were obtained in the presence of DTT, but that thioredoxin was active in hepatic as well as in non-hepatic systems. If expressed as a percentage of the values obtained with DTT, the efficiency of thioredoxin varied from $70 \%$ in liver to hardly $20 \%$ in spleen and kidney.

\title{
DISCUSSION
}

In vitro the conversion of vitamin $\mathrm{KO}$ to vitamin $\mathrm{K}$ has been shown to be absolutely dependent on synthetic dithiols such as dithiothreitol (2). Also, for the reduction of vitamin $\mathrm{K}$ the dithiol-dependent reductase is by far the most effective enzyme system (14). Although KO reductase was discovered more than 10 years ago (19), the physiological counterpart of its in vitro cofactor has never been discovered.

In this paper we have shown that the thioredoxin/thioredoxin reductase from E.coli is able to replace dithiothreitol during the in vitro carboxylation reaction. The activity obtained was about $40 \%$ of that in the presence of dithio- 
threitol. The thioredoxin/thioredoxin reductase system is also active in nonhepatic carboxylating enzyme systems. These experiments indicate that possibly the thioredoxin/thioredoxin reductase system is the physiological system which produces the reducing equivalents required for the reduction of vitamin $\mathrm{KO}$ and vitamin $\mathrm{K}$ in vivo. It is not unlikely that the thioredoxin/thioredoxin reductase system from bovine liver will prove to be an even more effective system for bovine liver carboxylase, since a substantial species specificity of thioredoxin has been reported (12). In fact it is surprising that bovine vitamin $\mathrm{KO}$ reductase and vitamin $\mathrm{K}$ reductase both recognize E.coli thioredoxin$(\mathrm{SH})_{2}$.

Based on our experiments we postulate an extension of the vitamin $\mathrm{K}$ cycle in which the oxidation of dithiothreitol is replaced by that of thioredoxin, whereas the oxidized thioredoxin is recycled via thioredoxin reductase + NADPH (fig. 4).

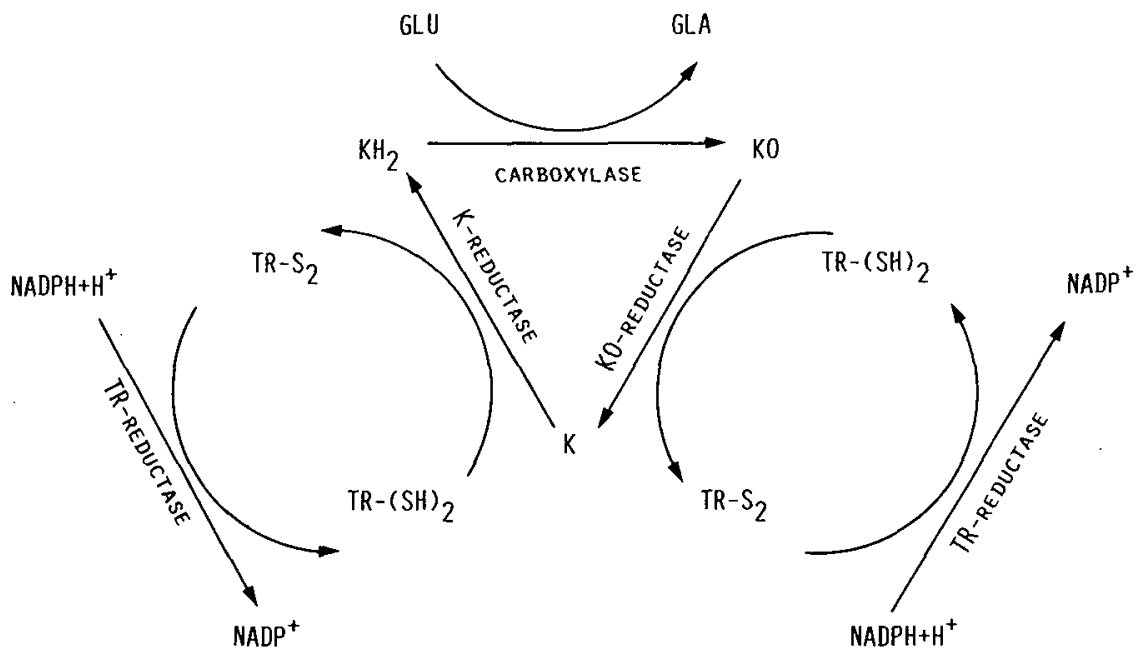

Fig. 4. Proposed extension of the vitamin $K$ cycle.

The synthetic dithiols from fig. 1 have been replaced by thioredoxin-(SH) 2 and the thioredoxin-(SH) 2 generating system (thioredoxin reductase + NADPH). TR, thioredoxin.

A practical aspect of our findings is that the thioredoxin/thioredoxin reductase provides a good alternative for the strongly reducing conditions 
(caused by the synthetic dithiols) during the in vitro carboxylation of disulfidecontaining substrates. This opens up the possibility of starting experiments in which protein substrates such as blood coagulation factor presursors [either present as an endogenous substrate complexed to carboxylase from warfarintreated animals or added as an exogenous substrate (e.g. obtained via recombinant-DNA technology)] are carboxylated in vitro without reducing the disulfide bonds in these proteins. This is a first requirement before the in vitro carboxylation of, for instance, blood coagulation factor IX precursors may be expected to increase the procoagulant activity of this protein.

\section{ACKNOWLEDGMENTS}

This work was supported by grant 900-526-052 from the Division for Health Research TNO. The authors wish to thank Dr. K. Hamulyák for his keen interest in our studies, Mr. F.N.G. Doornekamp for his technical assistance and Mrs. M. Molenaar-van de Voort for typing the manuscript.

\section{REFERENCES}

1. Olson, R.E. Ann.Rev.Nutr. 4: 281-337, 1984

2. Suttie, J.W. and Preusch P.C. Haemostasis 16: 193-215, 1986

3. Vermeer, C. New Compr. Biochem. 13: 87-101, 1986

4. Sherman, P.A. and Sander, E.G. Biochem. Biophys. Res. Commun. 103: 997-1005, 1981

5. Hildebrandt, E.F., Preusch, P.C., Patterson, J.L. and Suttie, J.W.Arch. Biochem. Biophys. 228: 480-492, 1984

6. Fasco, M.J., Hildebrandt, E.F. and Suttie, J.W. J. Biol. Chem. 257: 11210-11212, 1982

7. Preusch, P.C. and Suttie, J.W. Biochim. Biophys. Acta 798: 141-143, 1984

8. Wallin, R. and Suttie, J. Biochem. J. 194: 983-988, 1981

9. Wallin, R.S. and Hutson, S. J. Biol. Chem. 257: 1583-1586, 1982

10. Fasco, M.J. and Principe, L.M. Biochem. Biophys. Res. Commun. 104: 187-192, 1982

11. Holmgren, A., Ohlson, I. and Grankvist, M.L. J. Biol. Chem. 253: 430-436, 1978

12. Luthman, M. and Holmgren, A. Biochemistry 21: 6628-6633, 1982

13. Holmgren, A. and Luthman, M. Biochemistry 17: 4071-4077, 1978

14. De Metz, M., Soute, B.A.M., Hemker, H.C., Fokkens, R., Lugtenburg, J. and Vermeer, C. J. Biol. Chem. 257: 5326-5329, 1982

15. Soute, B.A.M., Ulrich, M.M.W. and Vermeer, C. Thrombos. Haemostas. 57: 77-81, 1987

16. De Metz, M., Vermeer, C., Soute, B.A.M. and Hemker, H.C. J. Biol. Chem. 256: 10843-10846, 1981

17. Sedmak, J.J. and Grossberg, S.E. Anal. Biochem. 79: 544-552, 1977

18. Wallin, R. and Martin, L.F. Biochem. J. 241: 389-396, 1987

19. Zimmerman, A. and Matschiner, J.T. Biochem. Pharmacol. 23: 1033-1040, 1974 
CHAPTER 3

STUDIES ON OSTEOCALCIN: A MODEL PROTEIN FOR THE DEVELOPMENT OF VARIOUS ASSAYS 



\title{
THE EFFECT OF GLA-CONTAINING PROTEINS ON THE PRECIPITATION OF INSOLUBLE SALTS
}

\author{
Peet G.F. van de Loo, Berry A.M. Soute, L. Johan M. van Haarlem \\ and Cees Vermeer
}

\section{SUMMARY}

The precipitation of insoluble salts containing divalent metal ions is inhibited by Gla-containing proteins of various origin. In this paper we demonstrate that:

1. Gla-residues are required for the inhibitory activity;

2. The inhibition is effected by a protein which in vivo is bound to calcified tissue (osteocalcin) as well as by proteins occurring in blood plasma (factor $\mathrm{X}$ ) and urine (the urinary Gla-protein);

3. The inhibitor concentration required for $50 \%$ precipitation-inhibition varied slightly from one salt to the other, but no marked differences were observed between the effects of the various Gla-containing proteins used;

4. Precipitation-inhibition occurred in all phosphates (Be, $\mathrm{Ca}, \mathrm{Mn}$ and $\mathrm{Zn}$ ) and in all calcium salts (phosphate, oxalate and carbonate) tested.

\section{INTRODUCTION}

Vitamin $\mathrm{K}$ is involved in the vitamin $\mathrm{K}$-dependent post-translational modification of proteins. The reaction at issue is the carboxylation of protein-bound glutamic acid residues into 4-carboxyglutamic acid (Gla) residues. Vitamin $\mathrm{K}$ in its hydroquinone form acts as a coenzyme for the carboxylating enzyme 
system, which is found in the microsomal fraction of various mammalian tissues (1-3). The function of Gla-residues in proteins is the relatively strong binding of $\mathrm{Ca}^{2+}$.

Numerous Gla-containing proteins have been discovered during the last few years, but those which have been characterized most extensively may be subdivided into two groups. The first group comprises the Gla-containing proteins which are produced by the liver (the blood coagulation factors II, VII, IX and $X$, the coagulation inhibiting proteins $C$ and $S$ ), and which mainly occur in blood plasma (4). The second group is formed by Gla-containing proteins mainly occurring in calcified tissues such as bone, dentin, renal stones and hardened atherosclerotic plaques (5-8). It seems probable that the Gla-containing protein found in renal stones is similar to the Glycoprotein Crystallization Inhibitor (GCI) described by Nakagawa et al. (9), which was obtained from human urine.

It has been reported that osteocalcin, the Gla-containing protein from bone, strongly inhibits the precipitation of calcium phosphate from supersaturated solutions of calcium and phosphate (5). Furthermore GCI was demonstrated to inhibit the calcium oxalate crystal growth (9). We have investigated a) if different Gla-containing proteins (blood coagulation factor $\mathrm{X}$, osteocalcin and the urinary Gla-protein) inhibit the precipitation of calcium phosphate to a similar extent; b) if these proteins also inhibit the precipitation of insoluble phosphates from other divalent metal ions and c) if they inhibit the precipitation of other insoluble calcium salts. The results of these investigations are presented in this paper.

\section{MATERIALS AND METHODS}

\section{Chemicals}

${ }^{7} \mathrm{BeCl}_{2}(350 \mathrm{Ci} / \mathrm{mmol}),{ }^{45} \mathrm{CaCl}_{2}(1.8 \mathrm{Ci} / \mathrm{mmol}),{ }^{54} \mathrm{MnCl}_{2}(5.4 \mathrm{mCi} / \mathrm{mmol})$ and $65 \mathrm{ZnCl}_{2}(65 \mathrm{Ci} / \mathrm{mmol})$ were purchased from Amersham International (UK) and Atomlight from New England Nuclear (Dreieich, F.R.G.). Bovine serum albumin was obtained from Sigma (St. Louis, U.S.A.). All chemicals were of the highest quality commercially available. 


\section{Proteins}

Blood coagulation factor $\mathrm{X}$ from bovine plasma was purified according to Fujikawa et al. (10) and osteocalcin from bovine bone as described earlier (11). The urinary Gla-protein was purified from human urine using the method described by Nakagawa et al. (9), except that the DEAE column chromatography was replaced by a batchwise adsorption to Ba-citrate, which was then washed with buffered saline and dissolved in a small volume of $0.5 \mathrm{M}$ EDTA, pH 8.0, and dialyzed against $0.1 \mathrm{M} \mathrm{NaCl}$ in $50 \mathrm{mM}$ Tris- $\mathrm{HCl}, \mathrm{pH} 7.0$ with at least three changes of the buffer.

\section{Precipitation-inhibition assays}

Non-labeled $\mathrm{CaCl}_{2}$ was supplemented with $20000 \mathrm{dpm}$ of the tracer $\left({ }^{45} \mathrm{CaCl}_{2}\right)$ and the Gla-protein to be tested. The reaction was started with a sodium phosphate buffer, $\mathrm{pH}$ 6.0. The final concentrations in the reaction mixtures $(1 \mathrm{ml})$ were $5 \mathrm{mM} \mathrm{CaCl}_{2}, 50 \mathrm{mM}$ phosphate and $0.15 \mathrm{M} \mathrm{NaCl}$. The mixtures were incubated in Eppendorff tubes for $2 \mathrm{~h}$ at $37^{\circ} \mathrm{C}$ and the precipitate which had formed during this period (if any) was spun down at $2000 \mathrm{x}$ g. From the supernatant $0.5 \mathrm{ml}$ was taken and counted. The same scheme was used for precipitation-inhibition studies with other phosphates, except that the concentration of the divalent kation varied slightly: $\mathrm{BeCl}_{2}, 0.6 \mathrm{mM} ; \mathrm{MnCl}_{2}$, $2.5 \mathrm{mM}$ and $\mathrm{ZnCl}_{2}, 0.6 \mathrm{mM}$. ${ }^{7} \mathrm{Be}$ was counted in a Packard 5360 Autogamma counter, the other isotopes in a Beckman LS1801 liquid scintillation counter using Atomlight as a scintillation liquid. The precipitation studies with calcium oxalate were performed in reaction mixtures containing $0.5 \mathrm{mM} \mathrm{CaCl} 2,150$ $\mathrm{mM} \mathrm{NaCl}, 3.75 \mathrm{mM}$ sodium oxalate, $0.1 \mathrm{M}$ bis-Tris- $\mathrm{HCl}, \mathrm{pH} 6.0$ and proteins as indicated. For the precipitation studies with calcium carbonate we used a freshly prepared solution containing $1 \mathrm{M} \mathrm{NaHCO}_{3}$, the $\mathrm{pH}$ of which had been adjusted to 6.5 by slowly adding $0.2 \mathrm{M} \mathrm{HCl}$. This solution was added to the rest of the reaction mixture in a 1:1 ratio $(\mathrm{v} / \mathrm{v})$ to give a final concentration of $5 \mathrm{mM} \mathrm{CaCl}_{2}, 0.15 \mathrm{M} \mathrm{NaCl}, 0.5 \mathrm{M} \mathrm{NaHCO}_{3}$ and proteins as indicated. The extent to which precipitation had occurred was calculated as follows. The radiolabel left in the supernatants of the precipitates formed in the absence of any protein added was regarded as a blanc value and was subtracted from all other data. Subsequently the radiolabel in the supernatant of precipitates formed in the presence of the various proteins was expressed as a percentage of the total amount of label added to the mixture. The IC-50 is defined as the protein concentration required for a $50 \%$ inhibition of precipitation and it was 
estimated from the in vitro protein concentration vs. precipitation-inhibition curves.

\section{Other assays}

Protein concentrations were measured according to Sedmak and Grossberg (12) and Gla-residues were detected after alkaline hydrolysis as described by Kuwada and Katayama (13). Thermal decarboxylation of Gla-containing proteins was accomplished by the method of Poser and Price (14).

\section{RESULTS}

\section{A. Inhibition of calcium phosphate precipitation by three different Gla-containing proteins.}

The Gla-containing proteins used in these experiments were chosen rather arbitrarily: bovine coagulation factor $\mathrm{X}$, bovine osteocalcin and the human urinary Gla-protein. The Gla-content of the purified preparations was 11.8, 2.9 and 2.4 residues per molecule, respectively. The effect of these three proteins on the precipitation of calcium phosphate from a supersaturated solution of calcium and phosphate is shown in fig. 1. The optimal conditions to visualize the effect were: $5 \mathrm{mM} \mathrm{CaCl}_{2}, 0.15 \mathrm{M} \mathrm{NaCl}$ and $50 \mathrm{mM}$ sodium phosphate, $\mathrm{pH} 6.0$ and they were similar for all three proteins tested. It is clear that all three proteins strongly inhibited the rate of calcium phosphate precipitation and that, when expressed on a molar base, the effects of the three proteins were closely similar. An incubation time of $2 \mathrm{~h}$ was chosen because during this period the precipitation of calcium phosphate in the absence of protein had amply reached plateau values. On the other hand it should be noted that also in the presence of Gla-containing proteins some precipitate was formed after prolonged incubations (24h). No inhibition of precipitation was observed in the presence of bovine serum albumin (fig. 1). Also after thermal decarboxylation of the Gla-residues in the three different proteins, no inhibitory activity could be detected, even at protein concentrations up to $30 \mu \mathrm{M}$ (data not shown). 


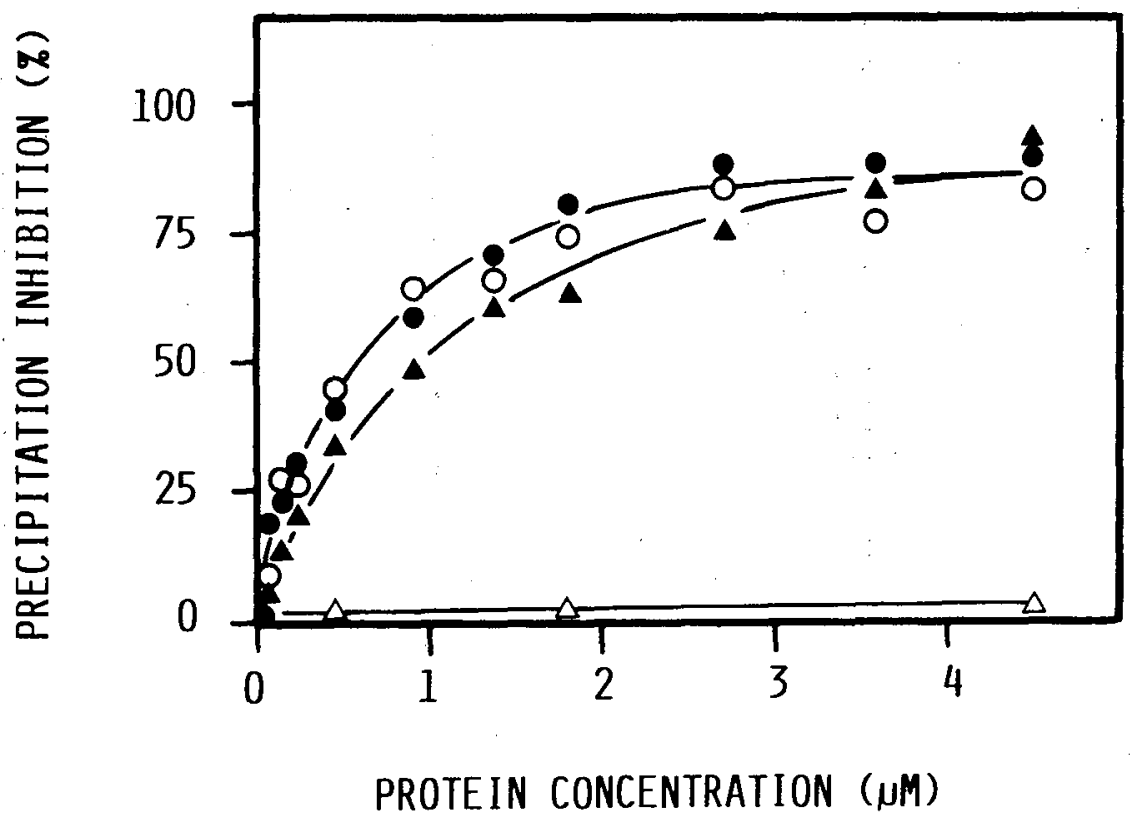

Fig. 1. Precipitation of calcium phosphate: inhibition by various proteins. Explanation of symbols: - , osteocalcin; $\mathrm{O}-\mathrm{O}$, urinary Gla-protein; $\boldsymbol{\Lambda}-\mathbf{A}$, coagulation factor $\mathrm{X} ; \Delta-\Delta$, bovine serum albumin.

\section{B. Precipitation-inhibition of insoluble phosphates.}

The optimal concentrations for visualizing the effect of the Gla-containing proteins on the calcium phosphate precipitation are not the same as those required for other salts. This is demonstrated in fig. $2 \mathrm{~A}$, where we have plotted the effect of osteocalcin on the precipitation of various insoluble phosphates under the conditions known to be optimal for calcium phosphate (5 $\mathrm{mM}$ of the divalent metal ion in $0.15 \mathrm{M} \mathrm{NaCl}$ and $50 \mathrm{mM}$ sodium phosphate, $\mathrm{pH}$ 6.0). By slightly adapting the kation concentration, however, the precipitation-inhibition could be demonstrated for all divalent metal ions tested (fig. 2B). Although the optimal conditions for performing these precipitation studies were different for the various salts, they were independent of the type of Gla-protein used.

In this way we have measured the IC-50 for all three Gla-containing proteins and the results are summarized in table $\mathrm{I}$. Without doubt the proteins tested inhibit the precipitation of all four phosphates to a comparable degree. 

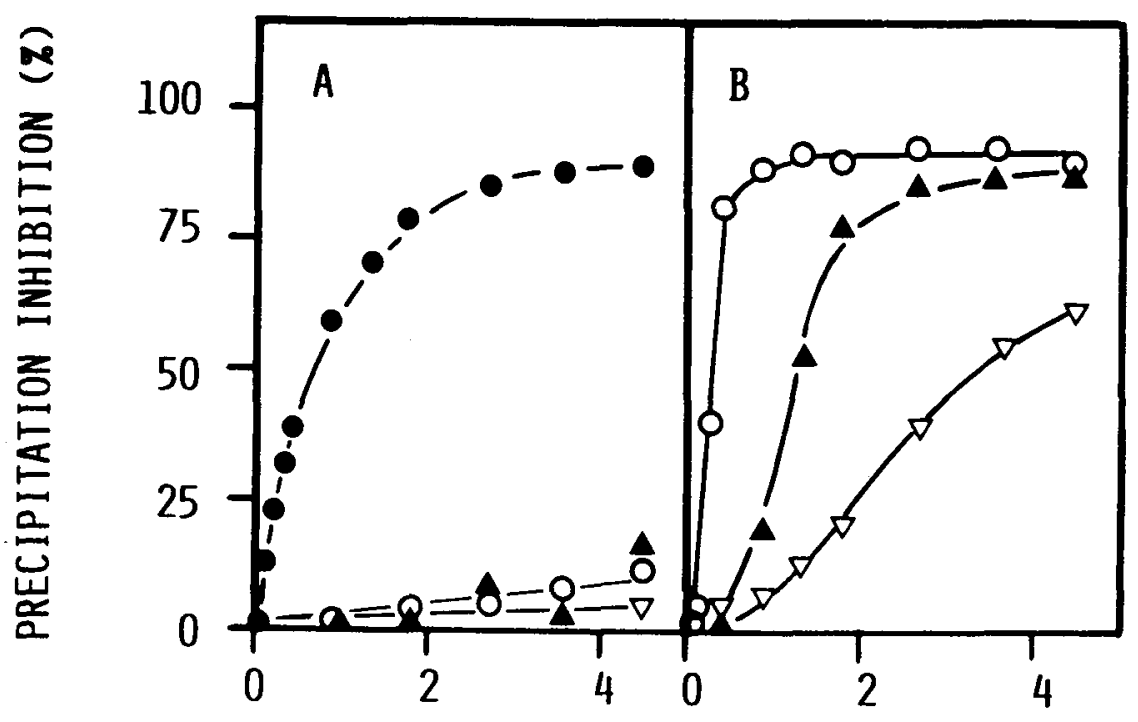

PROTEIN CONCENTRATION (NM)

Fig. 2. Precipitation of calcium salts under various conditions.

All experiments were performed in $0.15 \mathrm{M} \mathrm{NaCl}$ and $0.05 \mathrm{M}$ sodium phosphate, $\mathrm{pH}$ 6.0. In $\mathrm{A}$ the concentration of each of the divalent kations was $5 \mathrm{mM}$. In $\mathrm{B}$ the concentrations were: $0.6 \mathrm{mM} \mathrm{BeCl} 2,2.5 \mathrm{mM} \mathrm{MnCl} 2$ and $0.6 \mathrm{mM} \mathrm{ZnCl} 2$. Explanation of symbols: $-0, \mathrm{Ca}^{2+} ; \mathrm{O}-\mathrm{O}, \mathrm{Zn}^{2+} ; \nabla-\nabla, \mathrm{Mn}^{2+} ; \mathbf{\Delta}-\mathbf{\Lambda}, \mathrm{Be}^{2+}$.

TABLE I

Precipitation of insoluble phosphates: effect of various Gla-containing proteins

\begin{tabular}{lccc}
\hline Divalent & \multicolumn{3}{c}{ IC-50 $(\mu \mathrm{M})$ of: } \\
\cline { 2 - 4 } metal ion & factor X & osteocalcin & UGP \\
\hline $\mathrm{Be}^{2+}$ & 0.7 & 1.3 & 1.2 \\
$\mathrm{Ca}^{2+}$ & 0.9 & 0.6 & 0.6 \\
$\mathrm{Zn}^{2+}$ & 0.7 & 0.3 & 0.3 \\
$\mathrm{Mn}^{2+}$ & 4.0 & 3.4 & 2.5
\end{tabular}

Reaction mixtures contained: $0.15 \mathrm{M} \mathrm{NaCl}, 50 \mathrm{mM}$ sodium phosphate, $\mathrm{pH} 6.0$ and either $\mathrm{BeSO}_{4}(0.6 \mathrm{mM}), \mathrm{CaCl}_{2}(5 \mathrm{mM}), \mathrm{ZnCl}_{2}(0.6 \mathrm{mM})$ or $\mathrm{MnCl}_{2}(2.5 \mathrm{mM})$. Radiolabeled compounds were added in trace amounts and all incubations were performed for $2 \mathrm{~h}$ at $37{ }^{\circ} \mathrm{C}$. UGP stands for Urinary Gla-Protein. 


\section{Precipitation-inhibition of insoluble calcium salts.}

Finally we have also measured if the nature of the anion in a number of insoluble calcium salts might play a role in the extent to which the three Glacontaining proteins inhibit the salt precipitation. The three salts tested were calcium phosphate, calcium carbonate and calcium oxalate. The results of these experiments are shown in table II and it is clear that again all three proteins inhibit the precipitation. It should be noted, that phosphate and oxalate were tested at $\mathrm{pH} 6.0$ but that for carbonate a slightly higher $\mathrm{pH}(6.5)$ was used.

TABLE II

Precipitation of insoluble calcium salts:

effect of various Gla-containing proteins

\begin{tabular}{lccc}
\hline \multirow{2}{*}{ Anion } & \multicolumn{3}{c}{ IC-50 $(\mu \mathrm{M})$ of: } \\
\cline { 2 - 4 } & factor X & osteocalcin & UGP \\
\hline phosphate & 0.9 & 0.6 & 0.6 \\
carbonate & 0.2 & 0.1 & 0.1 \\
oxalate & 1.5 & 2.4 & 2.8
\end{tabular}

The reaction conditions were as described in Materials and methods and in the legend to table $\mathrm{I}$. UGP stands for Urinary Gla-Protein.

It is unlikely that the fact that the calcium carbonate precipitation shows the highest sensitivity towards Gla-containing proteins may be explained by the different reaction conditions, since control experiments with calcium phosphate and calcium oxalate (data not shown) demonstrated that at higher $\mathrm{pH}$ values increasing amount of the Gla-containing proteins are required to inhibit the precipitation of these salts.

\section{DISCUSSION}

Osteocalcin is a protein consisting of 49 amino acid residues, three of which are Gla-residues. It has been demonstrated some years ago (5) that even at very low protein concentrations osteocalcin is able to inhibit the precipitation of calcium phosphate from supersaturated solutions of calcium and phosphate. The urinary protein GCI has been characterized less thoroughly, but this protein was demonstrated to inhibit the calcium oxalate crystal growth (9). Here we have shown that it affects the precipitation of amorphous calcium phosphate 
as well. We were interested in the factors which play a role in the inhibition of calcium phosphate precipitation and we have investigated to which extent the following variables contribute to the inhibitory effect: 1) the nature of the Glacontaining protein; 2) the presence of Gla-residues in these proteins; 3 ) the type of the divalent metal ion and 4) the type of the anion.

It turned out that precipitation-inhibition occurred with all salts investigated, but that the conditions required to visualize the effect may vary slightly. Possibly these differences are related to the differences which exist between the various solubility products of the salts. Although the three Gla-containing proteins investigated were widely different with respect to their amino acid sequence and composition, their molecular mass and Gla-content, the precipitation-inhibition by these proteins was of the same order of magnitude when expressed on a molar base. This is in agreement with the observation of Romberg et al. (15) who showed that osteocalcin and prothrombin inhibit the hydroxyapatite crystal growth to a similar extent. The importance of the Glaresidues is clear from the fact that the inhibitory potency of the proteins was lost after they had been submitted to thermal decarboxylation. Since factor $\mathrm{X}$ contains 12 Gla-residues and osteocalcin and GCI only 3 it would be interesting to know whether partially carboxylated factor X (containing 3-11 Glaresidues) might have retained its full inhibitory activity.

From the results presented here we conclude that, although from a physiological point of view the interaction of Gla-residues with $\mathrm{Ca}^{2}+$ is more important than that with other metal ions, this interaction is far less specific than generally is assumed. Moreover, if it is true that osteocalcin is involved in the regulation of the calcium phosphate precipitation in vertebrate bone, similar proteins might be used by invertebrates for the regulation of $\mathrm{CaCO}_{3}$ precipitation. Unfortunately, the soluble matrix protein which has been suggested to regulate shell growth in oysters has not yet been tested for its Gla-content (16), but on the other hand it is at least striking that a Gla-containing protein has been found in hermatypic corals (17).

Since all three Gla-containing proteins inhibit the salt precipitation, even if these salts are present in a thousand fold excess, it seems that the proteins may interact with the nucleation site or the surface of a forming crystal in such a way that they prevent further accretion of the mineral. The fact that this protein-salt association takes place indicates that the proteins must have a much higher affinity for the precipitating salts than for the free metal ions, because otherwise one would expect that the Gla-residues in the proteins would be saturated with the divalent kations in solution. 


\section{ACKNOWLEDGMENTS}

The authors wish to thank Dr. K. Hamulyák for his critical remarks and Mrs. M. Molenaarvan de Voort for typing the manuscript. Our research is supported by grant 28-1150.7 from the Praeventiefonds, grant 84.463 from the Dutch Kidney Foundation and grant 13-30-52 from the Division for Health Research TNO.

\section{REFERENCES}

1. Suttie, J.W. Ann. Rev. Biochem. 54: 459-477, 1985

2. Olson, R.E. Ann. Rev. Nutr. 4: 281-337, 1984

3. Vermeer, C. and de Boer-van den Berg, M.A.G. Haematologia 18: 71-97, 1985

4. Prydz, H. Sem. Thrombos. Hemostas. 4: 1-14, 1977

5. Price, P.A., Otsuka, A.S., Poser, J.W., Kristaponis, J. and Raman, N Proc. Natl. Acad. Sci. USA 73: 1447-1451, 1976

6. Linde, A., Bhown, M., Cothran, W.C., Höglund, A. and Butler, W.T. Biochim. Biophys. Acta 704: 235-239, 1982

7. Lian, J.B., Prien, E.L., Glimcher, M.J. and Gallop, P.M. J. Clin. Invest. 59: 11511157,1977

8. Levy, R.J., Howard, S.L. and Oshry, L.J. Atherosclerosis 59: 155-160, 1986

9. Nakagawa, Y., Abram, V., Kézdy, F.J., Kaiser, E.T. and Coe, F.L. J. Biol. Chem. 258: $12594-12600,1983$

10. Fujikawa, K., Legaz, M.E. and Davie, E.W. Biochemistry 11: 4882-4891, 1972

11. Vermeer, C. FEBS Lett. 173: 169-172, 1984

12. Sedmak, J.J. and Grossberg, S.E. Anal. Biochem. 131: 173-179, 1977

13. Kuwada, M. and Katayama, K. Anal. Biochem. 131: 173-179, 1983

14. Poser, J.W. and Price, P.A. J. Biol. Chem. 254: 431-436, 1979

15. Romberg, R.W., Werness, P.G., Riggs, B.L. and Mann, K.G. Biochemistry 25: 11761180,1986

16. Wheeler, A.P., George, J.W. and Evans, C.A. Science 212: 1397-1398, 1981

17. Hamilton, S.E., King, G., Tesch, D., Riddles, P.W. Keough, D.T. Jell, J. and Zerner, B. Biochem. Biophys. Res. Commun. 108: 610-613, 1982 



\title{
THE QUANTIFICATION OF GAMMACARBOXYGLUTAMIC ACID RESIDUES IN PLASMA-OSTEOCALCIN
}

\author{
Berry A.M. Soute, Magda M.W. Ulrich, Marjo H.J. Knapen, \\ L. Johan M. van Haarlem and Cees Vermeer
}

\section{SUMMARY}

In this paper we describe an assay procedure for determining the amount of gammacarboxyglutamic acid (Gla) residues in serum- or plasma-osteocalcin. The test includes removing (by ethanol precipitation) the majority of the proteins from the plasma (e.g. the Gla-containing coagulation factors) and the specific extraction of osteocalcin with the aid of immobilized immunopurified antibodies. It is demonstrated that the Gla-content of circulating osteocalcin from normal cows is similar to that of osteocalcin obtained from bone. Hence, the fact that part of the newly synthesized osteocalcin does not bind to the hydroxyapatite matrix in bone cannot be explained by an undercarboxylation of the molecule.

\section{INTRODUCTION}

Osteocalcin, also designated as bone Gla-protein, is synthesized by the osteoblasts and it is predominantly found in bone tissue $(1,2)$. The precise 
function of osteocalcin is not known, but it is generally assumed that it plays a role in the regulation of calcium metabolism in bone. In vitro experiments have made clear that both the inhibition of calcium phosphate precipitation from a supersaturated solution as well as the binding of osteocalcin to hydroxyapatite are strongly related to the presence of three gammacarboxyglutamic acid (Gla) residues in the protein molecule (3). Therefore, it seems highly probable that only fully carboxylated osteocalcin is biologically active.

Although most of the newly synthesized osteocalcin remains in the bone tissue, a small part of it leaks into the blood stream where it may be detected and quantitated with a radioimmuno assay (4). The normal serum or plasma concentration varies widely from one species to the other $(4,5)$ and it is not known why the circulating osteocalcin has failed to bind to the hydroxyapatite crystals in bone. One of the reasons might be that the osteocalcin found in blood is not or only partly carboxylated. Since in elderly subjects partial carboxylation has even been described for osteocalcin from human bone (6) this possibility seemed likely.

We decided to develop a new technique that may be used to estimate the number of Gla-residues in plasma-osteocalcin. The cow was chosen as an experimental animal for these studies because antibodies against bovine osteocalcin were available and because bovine plasma contains rather high levels of osteocalcin $(60 \mathrm{ng} / \mathrm{ml})$.

\section{MATERIALS AND METHODS}

\section{Chemicals}

Osteocalcin RIA-kits were purchased from INCSTAR (Stillwater, U.S.A.) and CNBr-activated Sepharose and Sephadex G-50 from Pharmacia (Uppsala, Sweden). Carrier-free $125 \mathrm{I}$ was from the Radiochemical Center (Amersham, U.K.) Osteocalcin was purified from bovine bone according to Ulrich et al. (7) and polyclonal antibodies were raised in rabbits. Prothrombin was purified from bovine plasma as described by Owen et al. (8). All other chemicals were of the highest purity commercially available. 


\section{Preparation of antibodies}

Antibodies specifically directed against purified bovine osteocalcin were extracted from the immune serum by immunoadsorption onto Sepharosebound osteocalcin. The purified antibodies were eluted from the Sepharose with $0.5 \mathrm{M}$ sodium citrate, $\mathrm{pH} 3.0$ and dialyzed against buffer $\mathrm{A}(0.15 \mathrm{M} \mathrm{NaCl}$, $10 \mathrm{mM}$ Tris/HCl, $\mathrm{pH} 7.4$ ).

\section{Preparation of blood samples}

Aliquots $(2 \mathrm{ml})$ of bovine citrate plasma were supplemented with EDTA to a final concentration of $10 \mathrm{mM}$. After adding $4 \mathrm{ml}$ of ethanol (while shaking on a Vortex mixer), the samples were put for $10 \mathrm{~min}$ on ice and subsequently centrifuged for $10 \mathrm{~min}$ at $2500 \mathrm{x}$ g. The supernatant was made $10 \mathrm{mM}$ in $\mathrm{CaCl}_{2}$ and evaporated to dryness on a Rotavapor. The residue was resuspended in $2 \mathrm{ml}$ of water and extracted with Sepharose-bound immunopurified antibodies against osteocalcin $(0.1 \mathrm{ml}$ slurry $)$. Osteocalcin was eluted from the antibodies with $4 \mathrm{M} \mathrm{NaCNS}$ and after dialysis of the sample against buffer $\mathrm{A}$, $0.05 \mathrm{ml}$ was used for measuring the amount of osteocalcin antigen by radioimmuno assay, whereas the remaining part was used for the Gla-determination.

\section{Quantification of Gla-residues}

Gla was detected after alkaline hydrolysis of the samples using the method described by Kuwada and Katayama (9). This method is based on the separation of derivatized amino acids by HPLC. The various peaks were recorded and the surface areas were integrated automatically using a Kratos Spectroflow 980 fluorescence detector. These surface areas were regarded as a measure for the Gla-concentration in the sample. A reference curve was constructed with known amounts of purified Gla and used for the quantitation of the Gla concentration in the various plasma samples. By comparing these data with the antigen concentration, the number of Gla-residues per molecule of osteocalcin could be calculated.

\section{Other methods}

Protein concentrations were determined according to the method of Sedmak and Grossberg (10). 125I-labeling of proteins was performed with the choramine $\mathrm{T}$ technique as described by McConahey and Dixon (11). Thermal decar- 
boxylation of Gla-containing proteins was accomplished according to Price (12).

\section{RESULTS}

The most abundant Gla-containing proteins in blood plasma are prothrombin $(100 \mathrm{mg} / \mathrm{l})$ and coagulation factor $\mathrm{X}(10 \mathrm{mg} / \mathrm{l})$. Also the concentrations of the factors VII and IX and proteins $\mathrm{C}, \mathrm{S}$ and $\mathrm{Z}$ are much higher than that of osteocalcin $(4-7 \mu \mathrm{g} / \mathrm{l})$. A test for measuring the Gla-content of plasma-osteocalcin should therefore include a careful extraction of the osteocalcin from plasma, without contamination by one of the other Gla-containing proteins. To reach this goal, we have developed a two-step procedure: 1) the precipitation of the majority of the proteins (including the coagulation factors) from the plasma, and 2) the specific extraction of osteocalcin from the supernatant by immunoadsorption and elution. The recovery of osteocalcin antigen (as measured by radioimmuno assay) after the various steps is given in table $\mathrm{I}$.

TABLE I

Recovery of osteocalcin during its extraction from plasma

\begin{tabular}{|c|c|c|c|c|}
\hline Step & $\begin{array}{l}\text { Protein con- } \\
\text { centration } \\
(\mu \mathrm{g} / \mathrm{ml})\end{array}$ & $\begin{array}{l}\text { Osteocalcin con- } \\
\text { centration } \\
(\mathrm{ng} / \mathrm{ml})\end{array}$ & $\begin{array}{c}\text { Volume } \\
\text { (ml) }\end{array}$ & $\begin{array}{c}\text { Recovery } \\
(\%)\end{array}$ \\
\hline $\begin{array}{l}\text { STARTING PLASMA } \\
\text { ETHANOL PRECIPITATION }\end{array}$ & 76000 & 47 & 2 & 100 \\
\hline $\begin{array}{l}\text { precipitate (discard) } \\
\text { supernatant } \\
\text { RESUSPENDED RESIDIJE }\end{array}$ & $\begin{array}{l}71000 \\
\text { n.d. }\end{array}$ & $\begin{array}{l}<1 \\
\text { n.d. } \\
54\end{array}$ & $\begin{array}{r}2 \\
6 \\
7\end{array}$ & $\begin{array}{l}<2 \\
\text { n.d. } \\
07\end{array}$ \\
\hline $\begin{array}{l}\text { IMMUNOPURIFICATION: } \\
\text { effluent (discard) } \\
\text { eluate }\end{array}$ & $\begin{array}{l}380 \\
0.34\end{array}$ & $\begin{array}{r}3 \\
77\end{array}$ & $\begin{array}{l}5.3 \\
0.6\end{array}$ & $\begin{array}{l}17 \\
49\end{array}$ \\
\hline
\end{tabular}

After ethanol precipitation the precipitate was dissolved in buffer $\mathrm{A}$ and dialyzed before the various measurements were performed. The supernatant (containing $66 \%$ of ethanol) was evaporated to dryness before the protein and osteocalcin concentrations were established. n.d. $=$ not determined.

It turned out that the preparation thus contained about 3-fold more protein than osteocalcin, probably due to nonspecific adsorption onto the antibodycontaining Sepharose. Since prothrombin is the most abundant Gla-containing protein in plasma, this protein was selected as a marker to check if the contaminating proteins would be Gla-containing ones. 
Trace amounts of [125]]prothrombin $\left(125.10^{4} \mathrm{dpm}\right)$ were added to $10 \mathrm{ml}$ plasma samples, which were then subjected to the procedure developed for the extraction of osteocalcin. In parallel, control tubes containing [125I]osteocalcin (34 $000 \mathrm{dpm}$ ) instead of labeled prothrombin, were processed similarly.

TABLE II

Fractionation of plasma containing radiolabeled tracer proteins

\begin{tabular}{lcc}
\hline \multirow{2}{*}{ Step } & \multicolumn{2}{c}{ Recovery (dpm) } \\
\cline { 2 - 3 } & {$[125$ []osteocalcin } & {$[125]$ prothrombin } \\
\hline 1. STARTING PLASMA & 34000 & 1250000 \\
2. ALCHOHOL PRECIPITATION & 10000 & 1060000 \\
$\quad$ a. pellet (discard) & 27500 & 242200 \\
b. supernatant & 7400 & 240000 \\
3. MMUUNOADSORPTION & 16558 & 46 \\
$\quad$ a. nonbound (discard) & 4477 & 42 \\
b. bound to Sepharose & 11323 & 6 \\
4. ELUTION & a. Sepharose (discard) &
\end{tabular}

The amounts of labeled proteins added to $10 \mathrm{ml}$ of plasma were $20 \mathrm{ng}$ of osteocalcin and $1 \mu \mathrm{g}$ of prothrombin. The label bound to insolubilized anti-osteocalcin (step 3b) was measured after three washing cycles of the Sepharose with buffer A. In steps $3 b, 4 a$ and $4 b$ the whole samples were counted and a background of $21 \mathrm{dpm}$ was subtracted. The recovery of prothrombin in the final eluate (step 4b) was measured after 10 min counting and was almost indistinguishable from the background levels. The final recoveries were $33 \%$ for osteocalcin and less than 0.0005 $\%$ for prothrombin.

The results of this experiment are shown in table II and it is clear that no detectable (less than $0.05 \mathrm{ng}$ ) prothrombin was present in the final sample, whereas $33 \%$ of the total amount of osteocalcin was recovered. The latter figure is in good agreement with the recoveries as measured by radioimmuno assay (table I). From these experiments we have concluded that the contamination of immunopurified osteocalcin by other Gla-containing proteins is negligible. Samples containing immunopurified osteocalcin were subjected to alkaline hydrolysis and analyzed for their Gla-content. As shown in fig. 1A, the method is sufficiently sensitive to detect the presence of Gla in a sample obtained from $2 \mathrm{ml}$ of plasma. The position of Gla in the elution profile was routinely checked with purified Gla, which was mixed with an alkaline hydrolysate of bovine serum albumin $(1 \mathrm{mg} / \mathrm{ml})$ shortly before injecting the sample into the column (fig. 1B). The absolute amounts of Gla in the various samples 
were assessed by using a calibration curve as described in the Materials and methods section.

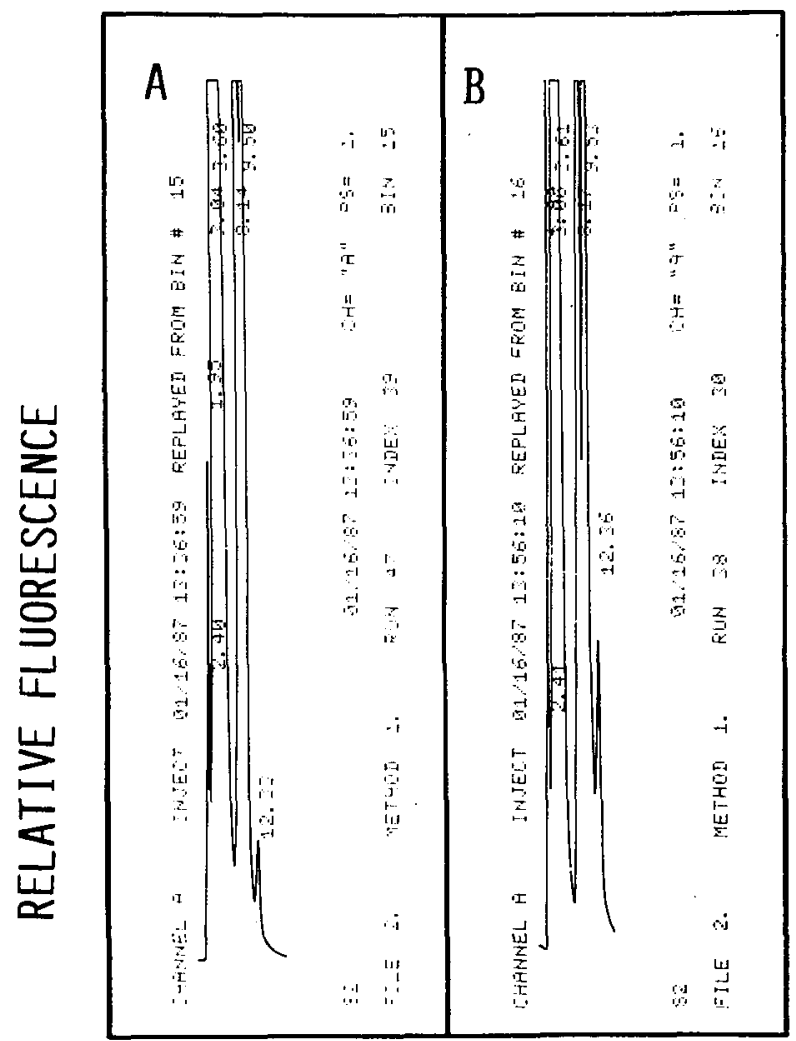

\section{TIME ELAPSED (MIN)}

Fig. 1. Separation profile of Gla-analysis.

Osteocalcin from $2 \mathrm{ml}$ of bovine plasma was isolated as described in Materials and methods, hydrolyzed in $4 \mathrm{M} \mathrm{KOH}$ and analyzed for its Gla-content (A). The position of Gla was verified with purified Gla, which was dissolved in an alkaline hydrolysate of albumin (B). The peak eluting after $12.36 \mathrm{~min}$ is Gla.

It was also checked if the Gla-content of the osteocalcin antigen would influence the data obtained by radioimmuno assay. For this purpose, osteocalcin was purified from bovine bone and the preparation was divided into two parts, one of which was brought at $\mathrm{pH} 8.0$, the other one at $\mathrm{pH} 2.0$. Both samples were frozen, lyophilyzed, and subjected to the conditions of thermal decarboxylation. After this procedure both samples were re-dissolved in buffer A and the $\mathrm{pH}$ was found to be 7.4. No Gla-residues had been lost in the sample 
kept at $\mathrm{pH} 8.0$, whereas no detectable Gla was present in the acid-treated one. The protein concentrations in both samples were similar, and osteocalcin was measured by radioimmuno assay in various dilutions (fig. 2). It turned out that the dose/response curves of both preparations were similar, which indicates that the radioimmuno assay does not discriminate between carboxylated and non-carboxylated osteocalcin.

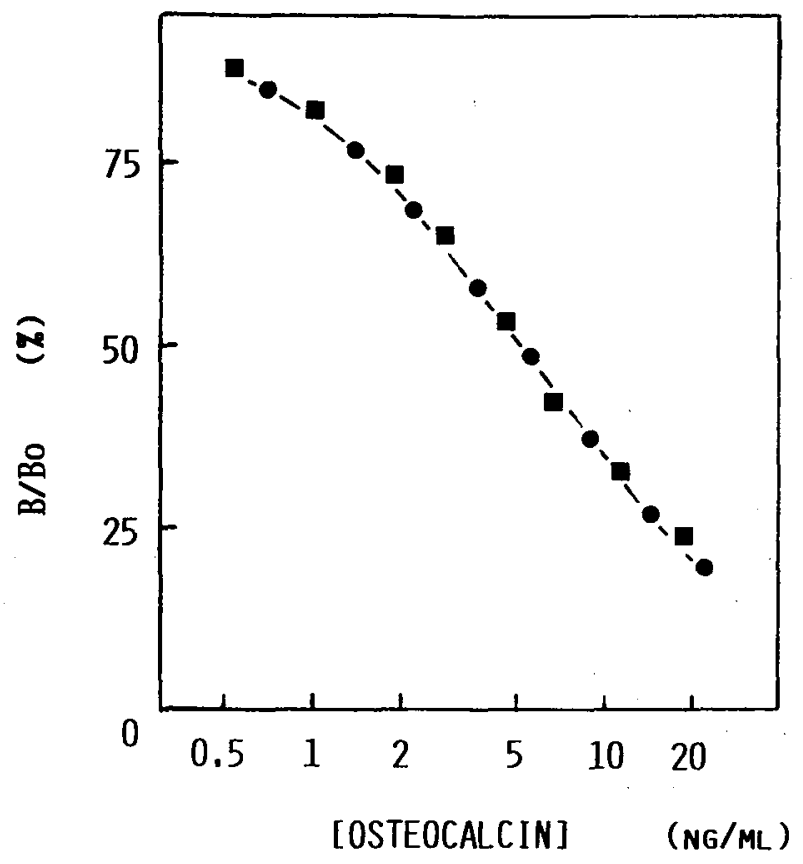

Fig. 2. Dose/response curve for normal and decarboxylated osteocalcin. Gla-containing (-) and Gla-deficient ( $\mathbf{( - 1}$ ) osteocalcin were tested in various dilutions by radioimmuno assay. B/Bo represents the percentage of label precipitated as compared with the sample containing the ${ }^{125}$ I-labeled tracer only.

Both the concentration of osteocalcin and the concentration of the Gla-residues derived from it could be measured unequivocally; the number of Gla-residues per molecule of plasma-osteocalcin could be calculated. This was done for 6 normal, healthy cows. The circulating osteocalcin antigen concentration in these animals ranged from 48 to $64 \mathrm{ng} / \mathrm{ml}$, which is normal for bovine plasma. The Gla-content of the plasma-osteocalcin was $2.7 \pm 0.4$ (S.E.M.) residues per molecule. Hence, we must conclude that circulating osteocalcin does not differ from that bound to the hydroxyapatite matrix in bone, at least not with respect to its Gla-content. 


\section{DISCUSSION}

In this paper we have demonstrated that osteocalcin in bovine plasma contains approximately 3 Gla-residues per molecule, which is comparable with the Gla-content of osteocalcin in bone. Plasma, and not serum, was used as a source of osteocalcin, in order to prevent as much as possible the formation of coagulation factor activation fragments. The unusual solubility of osteocalcin in ethanol $(67 \%, \mathrm{v} / \mathrm{v})$ was exploited to precipitate the bulk of bovine plasma proteins, and the efficacy of this precipitation step was checked with radiolabeled prothrombin. A second step, the specific immunoadsorption and elution of osteocalcin, was introduced to ensure that trace amounts of smaller peptides (e.g. activation peptides of the coagulation factors) were effectively removed from the osteocalcin sample. From the results obtained with this technique, it appeared that the reason for the leakage of newly synthesized osteocalcin into the blood stream is not caused by an inadequate vitamin $\mathrm{K}$-dependent carboxylation in the osteoblasts. A better explanation, which is consistent with in vitro experiments reported by Wians et al. (13) is that the binding of osteocalcin to hydroxyapatite is an equilibrium process with some fraction of osteocalcin always remaining free in the solution phase. Obviously this will lead to a flow of fully carboxylated osteocalcin from the extravascular fluid to the blood stream, where it may be detected by radioimmuno assay.

The technique developed to measure the Gla-content in plasma-osteocalcin is not restricted to bovine plasma, but may be used equally well in other species, but special attention must be paid to the quality of the antibodies used in the assay. In many cases use is made of the immunological cross-reactivity between osteocalcin from different species $(4,5)$. Whereas normal human osteocalcin, for instance, cross-reacts with antibodies against bovine osteocalcin, it is not known for sure if the same holds true for undercarboxylated osteocalcin.

The quantification of Gla-residues in plasma-osteocalcin is a technique that gives information about the quality of the circulating osteocalcin and hence it may be regarded as complementary to the radioimmuno assay, which is only quantitative. If adapted for human plasma and applied routinely when screening patients with various bone disease, this technique may be of help in our efforts to elucidate the function of osteocalcin in bone.

\section{ACKNOWLEDGMENTS}

This research was supported by grant 28-1150.7 from the Praeventiefonds, grant 13-30-52 from the Division for Health Research TNO and grant C84.463 from the Nier Stichting Nederland. The authors wish to thank Dr. K. Hamulyák for his keen interest in our studies, Mr. 
P.G.F. van de Loo for his technical assistance and Mrs. M. Molenaar-van de Voort for typing this manuscript.

\section{REFERENCES}

1. Hauschka, P.V. and Reid, M.L. J. Biol. Chem. 253: 9063-9068, 1978

2. Nishimoto, S.K. and Price, P.A. J. Biol. Chem. 254: 437-441, 1979

3. Price, P.A., Otsuka, A.S., Poser, J.W., Kristaponis, J. and Raman, N. Proc. Natl. Acad. Sci USA 73: 1447-1451, 1976

4. Price, P.A., Parthemore, J.G., Deftos, L.J. and Nishimoto, S.K. J. Clin. Invest. 66: 878-883, 1980

5. Patterson-Allen, P., Brautigem, C.E., Grindeland, R.E., Ashling, C.W. and Callahan, P.X. Anal. Biochem. 120: 1-7, 1982

6. Poser, J.W., Esch, F.S., Ling, N.C. and Price, P.A. J. Biol. Chem. 255: 8685-8691, 1980

7. Ulrich, M.M.W., Soute, B.A.M., van Haarlem L.J.M. and Vermeer, C. Thrombos. Haemostas. 57: 17-19, 1987

8. Owen, W.G., Esmon, C.T. and Jackson, C.M. J. Biol. Chem. 249: 594-605, 1974

9. Kuwada, M. and Katayama, K. Anal. Biochem. 131: 173-179, 1983

10. Sedmak, J.J. and Grossberg, S.E. Anal. Biochem. 79: 544-552, 1977

11. McConahey, P. and Dixon, F. Int. Arch. Allergy 29: 185, 1966

12. Price, P.A. Meth. Enzymol. 107: 548-551, 1984

13. Wians, F.H., Krech, K. and Hauschka, P.V. Magnesium 2: 83-92, 1983 
86 
$3 \mathrm{C}$

\section{CIRCULATING OSTEOCALCIN DURING ORAL ANTICOAGULANT THERAPY}

L. Johan M. van Haarlem, Marjo H.J. Knapen, Karly Hamulyák and Cees Vermeer

\section{SUMMARY}

In this paper we present the following observations:

1. In sheep vitamin $\mathrm{K}$ antagonists like phenprocoumon induce a decrease of the serum levels of osteocalcin (bone Gla-protein) and of the affinity of the circulating osteocalcin for hydroxyapatite.

2. In sheep vitamin $K$ counteracts the effect of phenprocoumon on the blood coagulation system, but not that on the osteocalcin production.

3. In human subjects vitamin $\mathrm{K}$ antagonists also lead to decreased levels of serum-osteocalcin and a low affinity of the protein for hydroxyapatite.

4. These two variables reached steady-state levels within $24 \mathrm{~h}$ after the start of oral anticoagulant treatment and - at continuation of the therapy - they remained low for at least several years. 


\section{INTRODUCTION}

Osteocalcin (also called: Bone Gla-Protein, BGP) is a Gla-containing protein synthesized by the osteoblasts in bone $(1,2)$. After its maturation and secretion by the bone cells, the protein remains predominantly bound to the hydroxyapatite matrix in bone. Less than $1 \%$ of the newly synthesized osteocalcin is set free in the blood stream, where it may be detected with a radioimmuno assay (RIA) (3). Similar to other Gla-containing proteins (e.g. prothrombin, protein C), vitamin $\mathrm{K}$ is involved in the formation of the Gla-residues in osteocalcin (4). It has also been described that vitamin $\mathrm{K}$ antagonists (warfarin, phenprocoumon, acenocoumarol), which are frequently used as oral anticoagulant drugs, are active in hepatic as well as in non-hepatic tissues (5-7). It must be expected, therefore, that during oral anticoagulant treatment the Gla-content of newly synthesized osteocalcin will be decreased. This will reduce its affinity for hydroxyapatite, so that increased levels of osteocalcin antigen are expected to be found in blood serum and plasma.

Indeed, it has been shown by Price et al. $(1,8)$ that warfarin treatment of rats leads to an increase of the serum-osteocalcin antigen and to a parallel decrease of its affinity for hydroxyapatite. In a subsequent paper from the same group (9) it was demonstrated that, although vitamin $\mathrm{K}$ counteracts the effect of warfarin on the synthesis of blood coagulation factors, a similar protection fails to occur for osteocalcin. Recently we have presented evidence (10) that the warfarin-insensitive NADH-dependent vitamin $\mathrm{K}$ reductase does not occur in the osteoblast-like osteosarcoma cell line UMR 106 and hence probably neither in normal rat osteoblasts. This might explain the results obtained for rat osteocalcin in various laboratories.

It is far from sure, however, that conclusions based on the rat system may be extrapolated to other species, including man. In a recent paper, for instance, Menon et al. (11), reported that during the initial stage of oral anticoagulant treatment of human subjects, the serum-osteocalcin levels had a tendency to decrease rather than to increase, whereas the affinity for hydroxyapatite was significantly reduced. To obtain more insight in the changes in serum- osteocalcin induced by coumarin-derivatives we have repeated the experiments of Price (9) in another experimental animal (sheep), and we have started clinical studies in which the characteristics of plasma-osteocalcin were measured during the first weeks of oral anticoagulant therapy as well as after long periods (more than three years) of deep and stable oral anticoagulation. The results of these investigations are presented in this paper. 


\section{MATERIALS AND METHODS}

\section{Materials}

Phenprocoumon (Marcoumar $\mathrm{R}$ ) and vitamin $\mathrm{K}_{1}$ (Konakion $^{\mathrm{R}}$ ) were obtained from Hoffmann-La Roche (Basle, Switzerland). All chemicals were analytical grade or better. Osteocalcin was prepared from sheep and human bone as described earlier (12) and thermally decarboxylated according to Poser and Price (13).

\section{Anticoagulated patients}

Six patients starting with oral anticoagulant therapy were investigated. The reasons for which they were treated were deep venous thrombosis $(n=5)$ and pulmonary embolism $(n=1)$. All patients were initially treated with heparin (intravenously), followed by acenocoumarol (dose adjusted to the thrombotest values). Their hepatic and renal functions were normal and none of them suffered from bone disease. Blood samples were taken before the start and during the initial phase (6-8 weeks) of the therapy at the dates indicated in fig. 3 . Long term anticoagulated patients $(n=74)$ had received oral anticoagulant therapy for a continuous period of at least three years and they were selected at random from the Maastricht Thrombosis Service.

\section{Normal subjects}

Age-matched, healthy individuals not receiving oral anticoagulants or other medication were used as a control group. Their plasma and serum samples were treated in exactly the same way as described for the anticoagulated patients.

\section{Anticoagulated sheep}

Four sheep (approximately $45 \mathrm{~kg}$ each) were treated with increasing doses of phenprocoumon (see fig. 1), which were administered twice daily by intramuscular injections. Two of the animals received an additional dose of vitamin $\mathrm{K}$ (10 mg daily, i.m.). The anticoagulant treatment was continued for 98 days, and one week after it was stopped also the administration of vitamin $\mathrm{K}$ was terminated. 


\section{Blood handling}

Blood was collected by venepuncture and used for the preparation of citrated plasma and serum. The various samples were frozen and stored at $\quad-80$ ${ }^{\circ} \mathrm{C}$ until the various series were completed. Before freezing, the plasma samples were tested in an overall coagulation assay (thrombotest (14)) to monitor the state of anticoagulation and after thawing they were tested once more with a specific one-stage prothrombin assay (13), and with a two-stage assay in which prothrombin and descarboxyprothrombin are converted to thrombin using Echis carinatus venom (15). Osteocalcin was tested in the serum samples with a commerical RIA kit (INCSTAR, Stillwater, USA) and its hydroxyapatite binding capacity was used to demonstrate the anticoagulantinduced decrease of protein-bound Gla-residues (9). In all experiments the fraction of osteocalcin which was bound to the hydroxyapatite is expressed as a percentage of the total serum concentration.

\section{RESULTS}

\section{A. Plasma-osteocalcin in anticoagulated sheep.}

Sheep were chosen as experimental animals, and before starting anticoagulant treatment it was verified if the plasma-osteocalcin concentrations could be adequately measured with the commercial RIA kit. It is well known that this kit contains antibodies against bovine osteocalcin, whereas also the labeled tracer is of bovine origin. Several authors have demonstrated the immunological crossreactivity between bovine and human $(3,16)$, ovine and human (17) and bovine, horse, monkey, baboon and cat osteocalcin (16). Dose-response curves of serum from these species were found to parallel the standard curves with bovine $(3,16)$ or ovine $(17)$ osteocalcin. We have found (data not shown) that also the dose-response curve of ovine serum was parallel to the bovine standard curve, which is generally considered proof of immunologic identity. It was also verified if the Gla-content of the osteocalcin antigen would influence the apparent osteocalcin concentrations as measured by RIA. For this purpose osteocalcin was extracted and purified from sheep and human bone and subjected to thermal decarboxylation. No significant difference in antigenic activity of the samples was found before and after the decarboxylation treatment. The effect of oral anticoagulant treatment was measured in an experiment in which we used four sheep. All animals received increasing but similar amounts of phenprocoumon during 98 days, but two of them were 


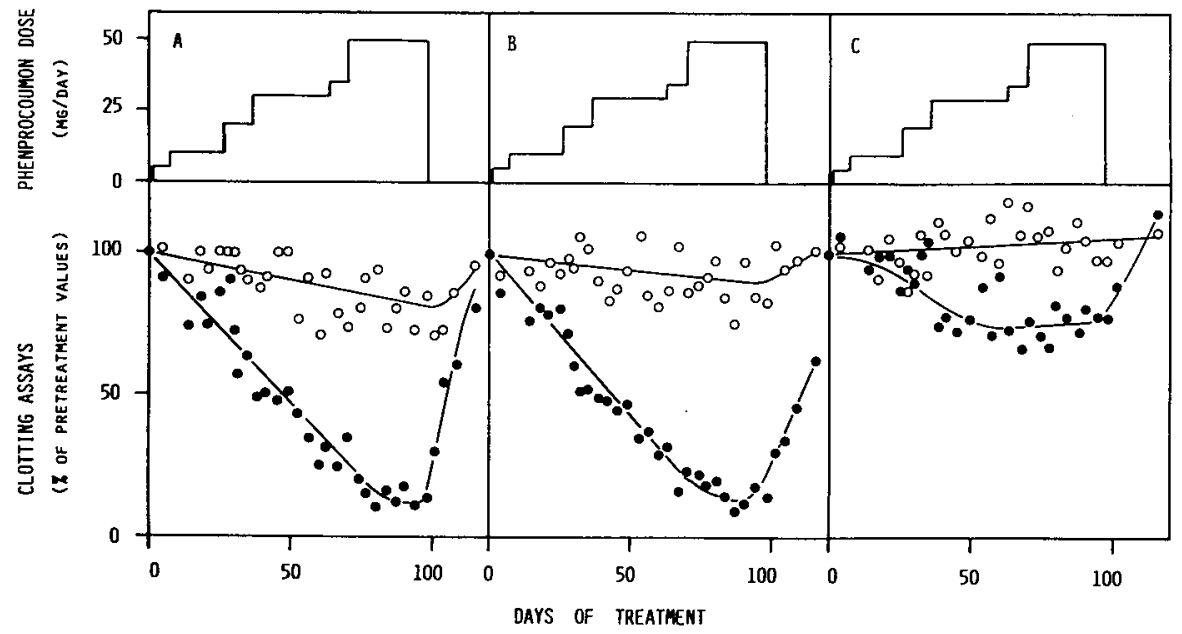

Fig. 1. Effect of phenprocoumon on blood coagulation factors in sheep.

Phenprocoumon was administered by an intramuscular injection and the daily dose is depicted in the upper panels. The lower panels show the effect of the medication on the thrombotest (A), prothrombin one-stage coagulation assay (B) and E. carinatus assay (C). Two sheep were treated with phenprocoumon only (closed symbols) and two animals received the same amount of phenprocoumon and vitamin $\mathrm{K}$ (10 $\mathrm{mg}$ daily) in addition (open symbols). All measurements were performed in duplicate and the means of the values obtained for the similarly treated sheep are given throughout this figure.

treated additionally with a high dose of vitamin $\mathrm{K}_{1}$ ( $10 \mathrm{mg}$ daily). The effect of the drugs on the blood coagulation system was routinely monitored with the thrombotest (fig. 1A) and in parallel also the concentrations of normal prothrombin and descarboxyprothrombin were evaluated with specific coagulation assays (fig. $1 \mathrm{~B}$ and $\mathrm{C}$ ). It appeared that as a result of the anticoagulant regimen, the procoagulant activity as measured by the thrombotest and the prothrombin assay steadily decreased during the 98 days period, whereas vitamin $\mathrm{K}$ gives a good protection against the anticoagulant effects of phenprocoumon. Subsequently we have assayed the osteocalcin concentrations in the same samples as described in fig. 1 and the results are presented in fig. $2 \mathrm{~A}$. In contrast to what might be expected from experiments in rats, the plasmaosteocalcin levels declined from the onset of the phenprocoumon treatment, and retumed to normal shortly after the treatment had stopped. It is also clear that the concurrent administration of vitamin $\mathrm{K}$ did not counteract this effect. 


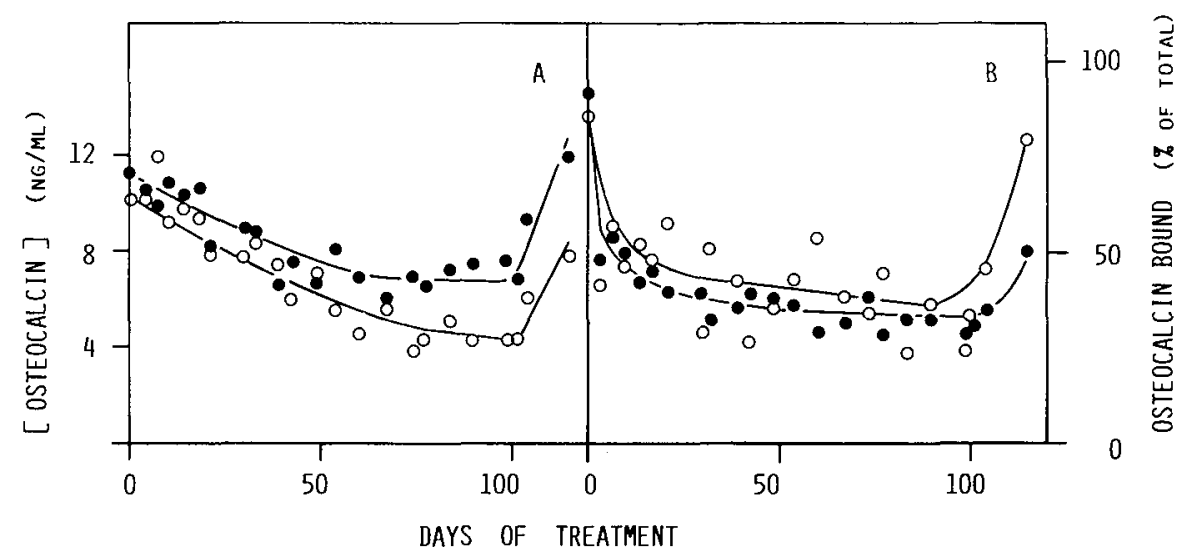

Fig. 2. Effect of phenprocoumon on serum-osteocalcin.

Serum-osteocalcin was measured before (A) and after (B) extraction with hydroxyapatite $(100 \mathrm{mg} / \mathrm{ml})$ in parallel samples as depicted in fig. 1. For further details: see legend to fig. 1 .

In fig. $2 \mathrm{~B}$ it is shown that also the Gla-content of the remaining plasma-osteocalcin (estimated from its hydroxapatite binding capacity) decreased as a result of the anticoagulant treatment, and also this variable was not affected by vitamin $\mathrm{K}$ administration.

\section{B. Serum-osteocalcin in anticoagulated patients.}

Blood was taken from patients during the initial phase of oral anticoagulant therapy. The effect of the medication on the blood coagulation system was monitored with the thrombotest and with the one-stage prothrombin assay, whereas the presence of descarboxyprothrombin can be deduced from the difference between the prothrombin procoagulant activity and the thrombin generation by Echis carinatus venom. The effect of the vitamin $\mathrm{K}$ antagonists on circulating osteocalcin was also measured in the various samples. The assays were performed in six different patients, four of which showed the normal profile of steadily decreasing thrombotest and prothrombin values. A typical example is given in fig. $3 \mathrm{~A}$. The other two patients had strongly fluctuating clotting times during the initial phase of the anticoagulant therapy and the medication had to be adjusted several times before a regimen was found which ensured stable anticoagulation. An example is shown in fig. 3B. It turned out, that in all cases the level of the serum-osteocalcin antigen decreased immediately after the start of the medication. In parallel also the affinity of osteocalcin for hydroxyapatite decreased from $70-75 \%$ (pre-treatment values) to less than 
$30 \%$ shortly after the start of the anticoagulant treatment. The low level of antigen in most samples did not permit us to determine these data more accurately, however.

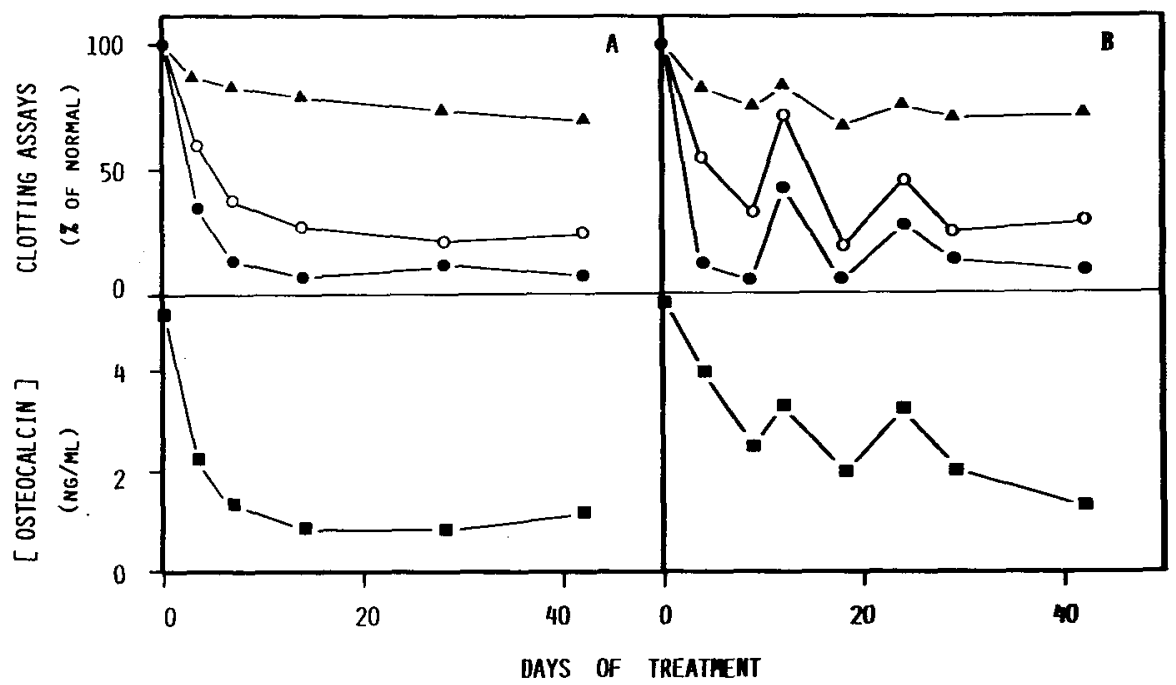

Fig. 3. Effect of acenocoumarol on coagulation factors and osteocalcin.

The panels A and B represent two different patients, the upper part of each panel shows the effect on various clotting assays and the lower parts the effect on serumosteocalcin, as measured in parallel samples. Explanation of symbols: thrombotest; $\mathrm{O}-\mathrm{O}$, one-stage prothrombin assay; $\boldsymbol{\Lambda}-\boldsymbol{\Lambda}$, two-stage $\mathrm{E}$. carinatus assay; $\mathbf{- 1}$, osteocalcin antigen.

Finally we also measured the serum-osteocalcin in patients on stable, longterm ( $>3$ years) anticoagulant therapy. The data are summarized in fig. 4 . In a group of 74 patients the antigen concentration was $1.9+0.9 \mathrm{ng} / \mathrm{ml}$ and hardly less after extraction of the samples with hydroxyapatite (data not shown). Again the level of antigen was too low to quantify more accurately the fraction of osteocalcin which had retained its affinity for hydroxyapatite. The range in an age-matched control group was $5.1+1.3 \mathrm{ng} / \mathrm{ml}$ and $25-35 \%$ of the antigen had no affinity for hydroxyapatite. Because no clear relation was observed between age and serum-osteocalcin antigen, the data obtained for the control group are plotted as one single population (fig. 4). In the same figure we have plotted the serum-osteocalcin of the patients in sub-groups of increasing age, but no relation between age and osteocalcin level was observed. The difference between the total group of patients and the controls, on the other hand, was 
highly significant (student's $t$ test: $p<0.001$ ), both with respect to the osteocalcin antigen as to its affinity for hydroxyapatite.

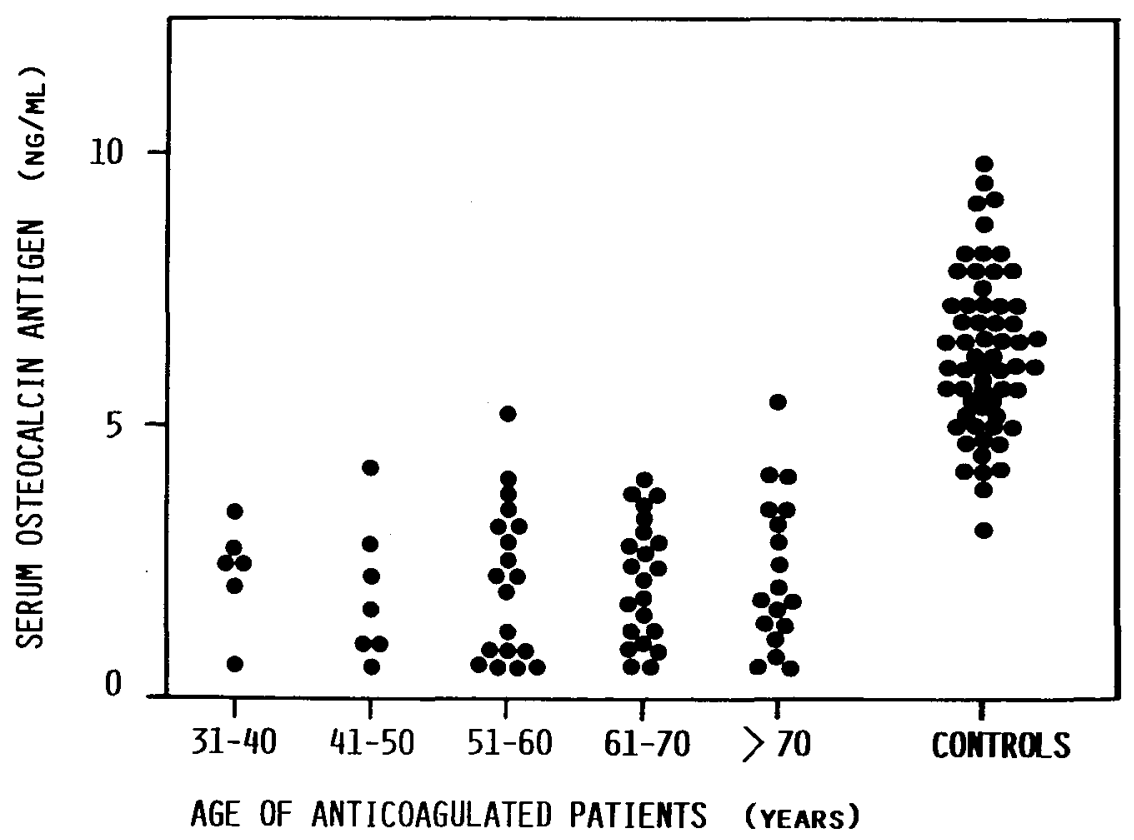

Fig. 4. Effect of acenocoumarol on circulating osteocalcin after long-term anticoagulant therapy.

All patients had been anticoagulated for at least 3 years.

\section{DISCUSSION}

In this paper we show that after the administration of vitamin $\mathrm{K}$ antagonists to sheep the circulating osteocalcin level as well as its affinity for hydroxyapatite decreased by more than $50 \%$. Because the affinity for hydroxyapatite reflects the Gla-content of the protein (although a linear relation between the two variables has never been shown), we conclude that the circulating osteocalcin was affected in a quantitative and in a qualitative way. A similar effect was observed in human subjects. Immediately after the start of the oral anticoagulant therapy both variables rapidly decreased and reached plateau levels as soon as stable anticoagulation was reached. Comparable values were obtained with long-term (3-10 years) anticoagulated subjects. It is remarkable, 
that fluctuation in the anticoagulation state, which occurred in two patients, were also reflected in the serum-osteocalcin levels.

The observation that vitamin $\mathrm{K}$ antagonists may decrease the circulating osteocalcin antigen level is surprising, because on theoretical grounds it is to be expected that a decreased Gla-content leads to a decreased affinity of osteocalcin for the inorganic bone matrix and hence to an increased excretion into the blood stream. This model seems to be correct for rodents $(1,8)$, but here it is demonstrated that in other species additional mechanisms may play a role. One of these mechanisms could be the excretion of descarboxyosteocalcin by the osteoblasts, which may be poor in man and sheep but much better in rats. This mechanism does not explain, however, why in non-treated subjects about $30 \%$ of the circulating osteocalcin does not bind to hydroxyapatite. It is also shown in this paper that the administration of vitamin $\mathrm{K}$ counteracted the effect of phenprocoumon on the blood coagulation system, but not that on the osteocalcin production. A similar observation has been reported in rats (9).

Obviously the sheep as an experimental animal has certain disadvantages relative to the rat. These disadvantages become increasingly pronounced if large numbers of animals are required in an experiment. On the other hand, it seems that certain aspects of bone metabolism in man are more comparable with that of sheep than that of rats. In this paper we demonstrate that for investigations concerning the effects of oral anticoagulants on bone metabolism, the sheep is probably more suitable than the rat, at least if the data obtained are to be extrapolated to the situation in man. This conclusion is based on the observation that sheep and human osteocalcin are similarly influenced by phenprocoumon (this chapter), whereas its effect on rat osteocalcin is opposite for one of the two variables measured $(1,8)$. Recently we have reported that vitamin $\mathrm{K}$ antagonists inhibit the carboxylase/reductase system in both hepatic and non-hepatic tissues. This inhibition was demonstrated in a number of warfarin-treated experimental animals $(5,7)$ as well as by comparing microsomal enzyme preparations from normal and anticoagulated human subjects (18). Here we demonstrate that, under the conditions normally applied for oral anticoagulant therapy, the carboxylase/reductase system in bone is inhibited to such an extent that the synthesis of osteocalcin (a nonhepatic Gla-protein) is strongly affected with respect to the amount of antigen produced as well as to its Gla-content. In anticoagulated subjects the fraction of circulating normal osteocalcin was about $25 \%$ of the control values. This is comparable to the fraction of prothrombin procoagulant activity in the blood plasma and hence it seems that the carboxylase/reductase systems in liver and in bone both are inhibited during oral anticoagulant therapy. 


\section{ACKNOWLEDGMENTS}

This research was supported by grant $28-1150$ from the Praeventiefonds and grant $86.028 \mathrm{~h}$ from the Dutch Heart Foundation. The authors wish to thank Mrs. M. Molenaar-van de Voort for typing the manuscript.

\section{REFERENCES}

1. Price, P.A., Williamson, M.K. and Lothringer, J.W. J. Biol. Chem. 24: 12760-12766, 1981

2. Nishimoto, S.K. and Price, P.A. J. Biol. Chem. 255: 6579-6583, 1980

3. Price, P.A. and Nishimoto, S.K. Proc. Natl. Acad. Sci. (USA) 77: 2234-2238, 1980

4. Pan, L.C. and Price, P.A. Proc. Natl. Acad. Sci. (USA) 82: 6209-6113, 1985

5. Roncaglioni, M.C., Soute. B.A.M., De Boer-van den Berg, M.A.G. and Vermeer, C. Biochem. Biophys. Res. Commun. 114: 991-997, 1983

6. De Boer-van den Berg, M.A.G., Thijssen, H.H.W. and Vermeer, C. Biochim. Biophys. Acta 884: $150-157,1986$

7 Van Haarlem, L.J.M., Ulrich, M.M.W., Hemker, H.C., Soute, B.A.M. and Vermeer, C. Biochem. J. 254: 251-255, 1987

8. Price, P.A. and Williamson, M.K. J. Biol. Chem. 256: 12754-12759, 1981

9. Price, P.A. and Kaneda, Y. Thrombos. Res. 46: 121-131, 1987

10. Ulrich, M.M.W., Knapen, M.H.J., Herrmann-Erlee, M.P.M. and Vermeer, C. Thrombos. Res. 50: 27-32, 1988

11. Menon, R.K., Gill, D.S., Thomas, M., Kernoff, P.B.A. and Dandona, P. J. Clin. Endocrinol. Metab. 64: 59-61, 1987

12. Vermeer, C., Soute, B,A,M,, Hendrix, H., and De Boer-van den Berg, M.A.G. FEBS Lett. 165: 16-20, 1984

13. Poser, J.W. and Price, P.A. J. Biol. Chem. 254: 431-436, 1979

14. Hemker, H.C., Veldkamp, J.J. and Loeliger, E.A. Thrombos. Diathes. Haemorrh. 19: 346-363, 1968

15. Vermeer, C., Soute, B.A.M. and Hemker, H.C. Thrombos. Res. 10: 495-507, 1977

16. Patterson-Allen, P., Brautigam, C.E., Grindeland, R.E., Asling, C.W. and Callahan, P.X. Anal. Biochem. 120: 1-7, 1982

17. Reid, I.R., Chapman, G.E., Fraser, T.R.C., Davies, A.D., Surus, A.S., Meyer, J., Huq, N.C. and Ibbertson, H.K. J. Clin. Endocrinol. Metab. 62: 379-383, 1986

18. De Boer-van den Berg, M.A.G., Thijssen, H.H.W. and Vermeer, C. Thrombos. Haemost. 59: 147-150, 1988 
CHAPTER 4

PLAQUE GLA-PROTEIN, A UNIQUE GLA-CONTAINING PROTEIN FROM CALCIFIED HUMAN ATHEROSCLEROTIC PLAQUES 



\title{
CHARACTERIZATION OF GLA-CONTAINING PROTEINS FROM CALCIFIED HUMAN ATHEROSCLEROTIC PLAQUES
}

\author{
L. Johan M. van Haarlem, Berry A.M. Soute, H. Coenraad Hemker and \\ Cees Vermeer
}

\section{INTRODUCTION}

Besides in the liver, vitamin $\mathrm{K}$-dependent carboxylase also occurs in many non-hepatic tissues including the vessel wall (1). The Gla-containing proteins produced by the hepatic enzyme are excreted into the blood stream where at least six of them are involved in the blood coagulation process. They all belong to the circulating Gla-proteins. A second class of Gla-proteins comprises those found in calcified tissues such as bone, dentin, renal stones and hardened atherosclerotic plaques $(2,3)$. In this paper we will focus our attention to the plaque proteins. Obviously they might originate either from the blood stream from which they could have been adsorbed or, alternatively, they might be produced by vessel wall carboxylase. Before information about their origin may be obtained, a thorough characterization of these proteins seems to be warranted.

The information obtained from the literature is confusing. In 1979 a Glacontaining protein was discovered in hardened atheromatous plaques and because of its calcium-binding properties it was designated as atherocalcin (2). Later on it was reported by the same group that atherocalcin was merely a 
complex between osteocalcin and albumin (3) and that this complex accounted for only a small part of the total amount of Gla-residues in EDTA-extracts of calcified plaques. The nature of the remaining proteins has remained obscure up till now. We have tried to characterize more completely the protein constituents of calcified plates in human aortas and the results of our investigations are presented in this paper.

\section{MATERIALS AND METHODS}

\section{Chemicals}

Benzamidine hydrochloride was obtained from Janssen Chimica (Beerse, Belgium), trasylol from Bayer (Leverkusen, F.R.G.) and human serum albumin from Nordic Laboratories (Tilburg, The Netherlands). Soybean trypsin inhibitor and guanidine hydrochloride (guanidine/ $\mathrm{HCl}$ ) were purchased from Sigma (St. Louis, U.S.A.) ${ }^{45} \mathrm{CaCl}_{2}(1.8 \mathrm{Ci} / \mathrm{mmol})$ was obtained from Amersham International (Amersham, U.K.) and Atomlight from New England Nuclear (Dreieich, F.R.G.) CNBr-activated Sepharose and QAE-Sephadex were purchased from Pharmacia (Uppsala, Sweden) and $\mathrm{NH}_{4} \mathrm{HCO}_{3}$ from Baker Chemicals (Deventer, The Netherlands). All other chemicals were obtained from Merck (Darmstadt, F.R.G.). Spectrapor 3 dialysis tubing (molecular weight cutt of: 3,500 D) was from Spectrum Industries (Los Angeles, U.S.A.) and was used for all dialyses.

\section{Antibodies}

Osteocalcin was purified as described earlier (4). Antibodies against this protein were raised in rabbits and purified from the crude immune sera by immunoaffinity chromatography. Antibodies against purified human prothrombin and factor $\mathrm{X}$ were purchased from the Central Laboratory of the Netherlands Red Cross Blood Transfusion Service (Amsterdam, The Netherlands), antibodies against human serum albumin were from Nordic Laboratories (Tilburg, The Netherlands) and antibodies against human protein $\mathrm{C}$ were a kind gift from Dr. R.M. Bertina (Leiden, The Netherlands). 


\section{Tissue preparation}

Human atherosclerotic aortas $(n=50)$ were obtained at autopsy between 5 and $24 \mathrm{~h}$ after death and stored at $-60{ }^{\circ} \mathrm{C}$ until use. The aortas were dissected free of surrounding tissue and fat and rinsed in buffered saline to remove contaminating blood. Areas of discrete, hard calcification were excised and pooled. Subsequently a liquid nitrogen milled powder was prepared from these tissue pools and $50 \mathrm{~g}$ of powder was extracted for 8 days at $4{ }^{\circ} \mathrm{C}$ in a buffer containing $1.0 \mathrm{M}$ EDTA, $0.2 \mathrm{M} \mathrm{KCl}, 4.0 \mathrm{M}$ guanidine/ $\mathrm{HCl}(\mathrm{pH} 8.0)$ in the presence of the following protease inhibitors: benzamidin $(0.01 \mathrm{M})$, trasylol $(100,000 \mathrm{KIE}$ per litre) and soybean trypsin inhibitor $0.02 \%$, w/v). The extraction buffer was renewed after 4 days. Insoluble material was removed by centrifugation at $10,000 \times \mathrm{g}$ for $15 \mathrm{~min}$ at $4{ }^{\circ} \mathrm{C}$ and the proteins extracted were diluted 20-fold with distilled water followed by a batchwise adsorption onto QAE-Sephadex in $0.15 \mathrm{M} \mathrm{NaCl}, 0.05 \mathrm{M}$ Tris/ $\mathrm{HCl}$ (pH 8.0) using $10 \mathrm{ml}$ of slurry per 1 diluted extract. Subsequently the adsorbed proteins were eluted with $1.0 \mathrm{M} \mathrm{NaCl}, 0.05 \mathrm{M}$ Tris/ $\mathrm{HCl}$ ( $\mathrm{pH} 8.0$ ) and the eluate was dialyzed extensively against distilled water to remove EDTA and other salts. After lyophilization and another extensive dialysis against $0.05 \mathrm{M} \mathrm{NH}_{4} \mathrm{HCO}_{3}$, the protein fraction obtained was centrifuged at $2,000 \mathrm{x} \mathrm{g}$ for $10 \mathrm{~min}$ at $4{ }^{\circ} \mathrm{C}$. The resulting supernatant was designated as the calcium plate extract.

\section{Precipitation-inhibition studies}

The protein solutions to be tested were dialyzed against $0.15 \mathrm{M} \mathrm{NaCl}, 0.05$ M Tris/ $\mathrm{HCl}$ (pH 7.4) prior to use. Non-labeled $\mathrm{CaCl}_{2}$ was supplemented with $20,000 \mathrm{dpm}$ of the tracer $\left({ }^{45} \mathrm{CaCl}_{2}\right)$ and the proteins to be tested. The optimal reaction conditions for studying the calcium phosphate precipitation were: 5 $\mathrm{mM} \mathrm{CaCl} 2,150 \mathrm{mM} \mathrm{NaCl}$ and $5 \mathrm{mM}$ sodium phosphate, $\mathrm{pH} 7.4$. The mixtures were incubated in Eppendorf tubes for $2 \mathrm{~h}$ at $37{ }^{\circ} \mathrm{C}$ and the precipitate formed (if any) was spun down at $2,000 \mathrm{xg}$. Subsequently $0.5 \mathrm{ml}$ from the supernatant was taken and counted in a Beckman LS 1801 liquid scintillation counter using Atomlight as a scintillation liquid. For the precipitation studies with calcium carbonate we used a freshly prepared solution containing $250 \mathrm{mM}$ sodium bicarbonate, the $\mathrm{pH}$ of which had been adjusted to 7.4 by slowly adding $1 \mathrm{M}$ $\mathrm{HCl}$. The reaction mixtures contained $5 \mathrm{mM} \mathrm{CaCl} 2,150 \mathrm{mM} \mathrm{NaCl}, 125 \mathrm{mM}$ $\mathrm{NaHCO}_{3}$ and proteins as indicated. The extent to which a certain protein was able to inhibit the precipitation of calcium salts was quantitated as follows. The radiolabel which had remained in solution in the absence of any protein was 
regarded as a blank value and was subtracted from the data obtained in the presence of the protein. Subsequently the difference between these two figures was expressed as a percentage of the total amount of label added to the reaction mixture.

\section{Various assays}

The composition of the mineral deposits of human atherosclerotic aortas was determined by infra-red spectroscopy analysis and by stone analysis (ready prepared kit from Temmler Diagnostika (Marburg, FRG)). Protein concentrations were measured according to Sedmak and Grossberg (5) and Gla and Glu residues were determined after alkaline hydrolysis of the proteins as in (6). Decarboxylation of Gla-containing proteins was accomplished as described in (7). The presence of osteocalcin was determined with a radioimmuno assay (Immuno Nuclear Company). High performance liquid chromatography (HPLC) was carried out using a Bio-Sil TSK-250 size-exclusion column (BioRad, $600 \times 21.5 \mathrm{~mm}$ ). Polyacrylamide gel electrophoresis in the presence of SDS was performed with ready prepared Phast Gel gradient 10-15 gels with a continuous gradient from 10 to $15 \%$ polyacrylamide in combination with Phast Gel SDS buffer strips. The gels were stained with Coomassie Brilliant Blue and destained following the recommendations of the manufacturer. The Phast Gel electrophoresis system as well as the ready prepared polyacrylamide Phast Gels were products of Pharmacia (Sweden).

\section{RESULTS}

Sediment analysis of a powder of $50 \mathrm{~g}$ of calcified plaques demonstrated that the mineral phase mainly consisted of calcium phosphate and calcium carbonate. Since the procedure used to solubilize the mineralized material includes a dialysis step of 1 week it may be expected that low molecular weight material (e.g. free or peptide-bound Gla) had been removed from the organic phase. Yet substantial amounts of Gla were detected in alkaline hydrolysates of the calcium plate extract (data not shown). 
TABLE I

Characterization of the calcium plate extract

\begin{tabular}{llll}
\hline $\begin{array}{l}\text { Sepharose-bound } \\
\text { antibodies }\end{array}$ & $\begin{array}{c}\text { Gla } \\
(\mathrm{ng} / \mathrm{ml})\end{array}$ & $\begin{array}{l}\text { Protein } \\
(\mathrm{mg} / \mathrm{ml})\end{array}$ & $\begin{array}{l}\text { Gla/Protein } \\
(\mathrm{ng} / \mathrm{mg})\end{array}$ \\
\hline a. None & 315.0 & 0.41 & 768.3 \\
b. Murine IgG & 302.0 & 0.40 & 755.0 \\
c. Anti-prothrombin & 292.5 & 0.39 & 750.2 \\
d. Anti-factor X & 292.0 & 0.39 & 748.7 \\
e. Ant-protein C & 290.0 & 0.39 & 743.6 \\
f. Anti-osteocalcin & 254.4 & 0.40 & 636.0 \\
g. Anti-albumin & 273.6 & 0.38 & 729.0 \\
h. f + g & 221.2 & 0.39 & 567.2
\end{tabular}

Samples containing $0.2 \mathrm{ml}$ calcium plate extract, $0.1 \mathrm{ml}$ of Sepharose slurry and $0.1 \mathrm{ml}$ of buffer $0.1 \mathrm{ml} \mathrm{NaCl}, 0.05 \mathrm{M}$ Tris/ $\mathrm{HCl}\left(\mathrm{pH} 7.4\right.$ ) were rotated end over end overnight at $4^{\circ} \mathrm{C}$. Subsequently the tubes were centrifuged for 5 minutes at $2000 \mathrm{xg}$ and aliquots $(0.2 \mathrm{ml})$ from the supernatants were taken for protein and Gla determination. Immobilized murine IgG was used as a control to exclude non-specific binding to the Sepharose. It was verified in all cases that increasing the amount of Sepharose-bound antibodies did not affect the data. In the experiment described in line a buffer was added in stead of Sepharose. The results are the mean values of duplicate measurements.

We have investigated if the Gla-proteins in the calcium plate extract were related to one of the most abundant Gla-proteins in plasma (prothrombin, factor $\mathrm{X}$ and protein $\mathrm{C}$ ) or to osteocalcin and/or albumin. These experiments were perfomed by incubating the extract with immobilized immunopurified antibodies against each of the various proteins. The decrease of the total amount of Gla in the supernatant fraction was taken as a measure for the amount of antigen removed. The results of these experiments are summarized in table I and it is obvious that none of the (anti-)coagulation factors could be detected in the plate extract. Only the antibodies against osteocalcin and, to a lesser degree, albumin were able to bind part of the Gla-proteins, but even the combination of the two antibodies resulted in a removal of only one third of the protein-bound Gla residues. The presence of osteocalcin in the calcium plate extract was confirmed by radioimmuno assay, which showed that the preparation contained $210 \mathrm{ng}$ osteocalcin per $\mathrm{mg}$ of protein. This is somewhat less than the amount calculated from table $I$, but it should be kept in mind that if osteocalcin occurs as a complex with albumin the data obtained by RIA will probably underestimate the actual osteocalcin concentration.

We have also investigated to what extent the extracted plaque proteins affected the in vitro precipitation of calcium phosphate and of calcium carbonate from a supersaturated solution. These two salts are the main constituents of the inorganic phase of the plaques. 


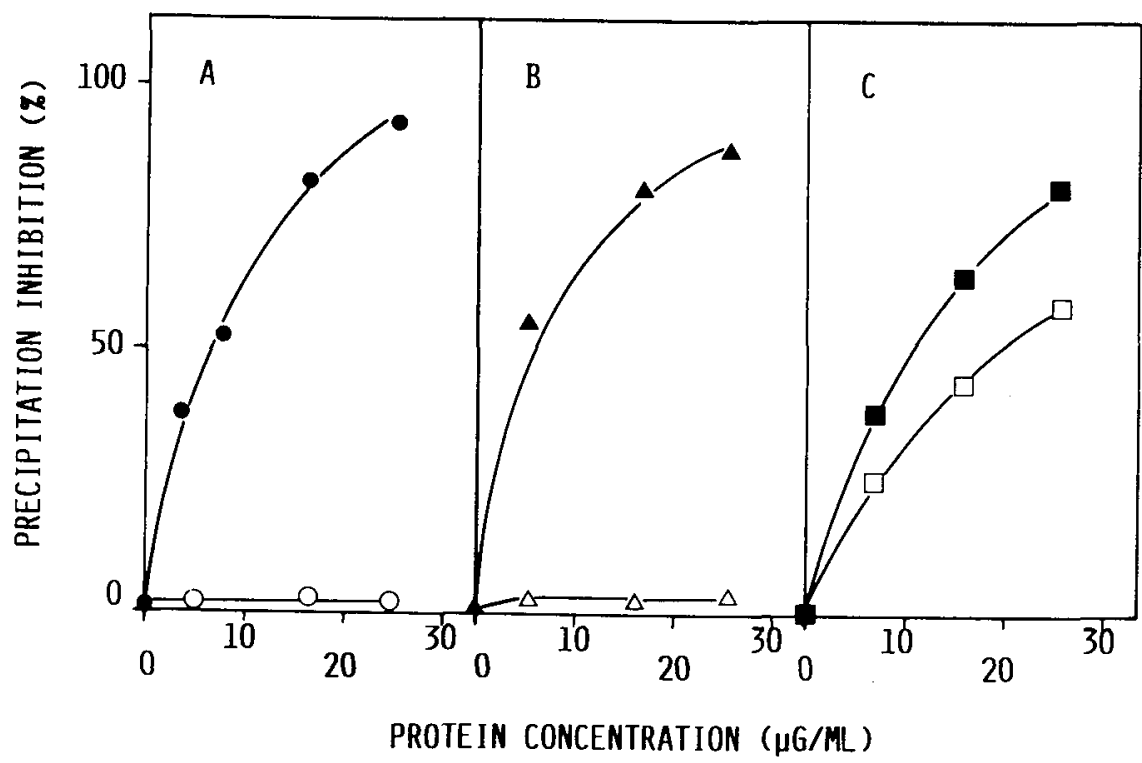

Fig. 1. Effect of various proteins on the precipitation of calcium carbonate.

The precipitation-inhibition activity of the calcium plate extract was measured before (A) and after (B) thermal decarboxylation and after removal of osteocalcin (C).

The incubations were performed for $2 \mathrm{~h}$ at $37^{\circ} \mathrm{C}$ as described in the Material and methods section. Explanation of symbols: -0 , calcium plate extract; $\mathrm{O}-\mathrm{O}$, human serum albumin; $\boldsymbol{\Delta}-\boldsymbol{\Delta}$, d-calcium plate extract $\mathrm{pH} 8 ; \Delta-\Delta$, d-calcium plate extract $\mathrm{pH} 2 ; \square-\square$, calcium plate extract after treatment with anti-osteocalcin; $\square-\square$, calcium plate extract after treatment with anti-osteocalcin and anti-albumin.

It resulted that at a physiological $\mathrm{pH}$ (7.4) the plate extract strongly inhibits the precipitation of calcium carbonate (fig. 1A) and calcium phosphate (data not shown). Human serum albumin (lacking Gla residues) had no effect, even at concentrations up to $50 \mu \mathrm{g} / \mathrm{ml}$. The role of Gla-residues in the precipitationinhibitory activity was demonstrated in an experiment in which the plate extract was dialyzed against distilled water and divided into two parts, one of which was brought to $\mathrm{pH} 2.0$ and the other one to $\mathrm{pH} 8.0$. After lyophilyzation both preparations were subjected to the conditions of thermal decarboxylation $\left(24 \mathrm{~h}\right.$ at $110^{\circ} \mathrm{C}$ in vacuo) and redissolved in Tris-buffered saline ( $\mathrm{pH} \mathrm{7.4).} \mathrm{The}$ $\mathrm{pH}$ was checked at this stage and adjusted, if required. The acid-treated preparation did not contain protein-bound Gla-residues any more, whereas Gla 
in the other sample had remained unchanged. As shown in fig. 1B, only the Gla-containing sample had retained its precipitation-inhibitory activity. Since also osteocalcin has been reported to inhibit the precipitation of insoluble calcium salts (8) the calcium plate extract was depleted of osteocalcin and of albumin/osteocalcin complexes (if any) by incubating the sample with an excess of Sepharose-bound antibodies against osteocalcin and albumin. As shown in fig. $1 \mathrm{C}$, also the osteocalcin-depleted plate extract strongly inhibited the precipitation of calcium carbonate. From these data we concluded that the calcium plate extract must contain a hitherto unidentified Gla-protein and we have decided to purify the latter.

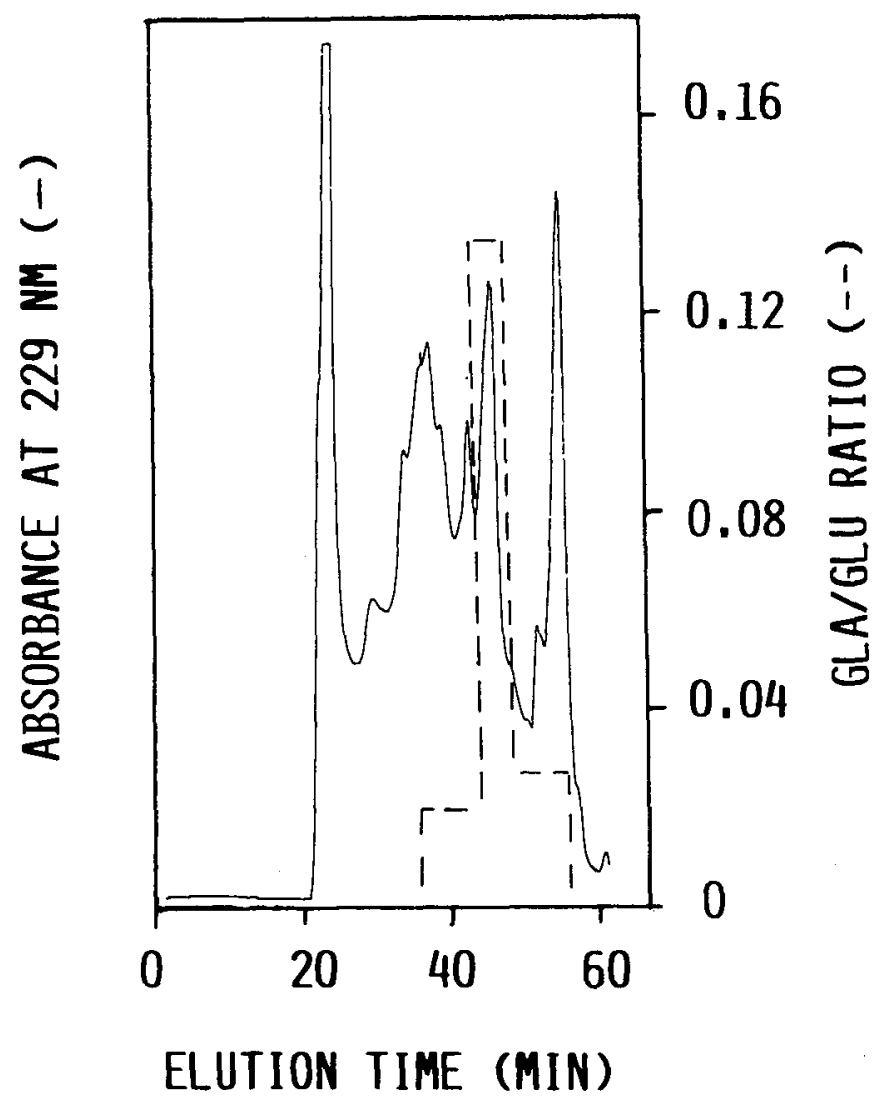

Fig. 2. Fractionation of calcium plate extract on a Bio-Sil TSK-250 column. The flow rate was adjusted to $240 \mathrm{ml} / \mathrm{h}$ and the absorbance of the effluent was monitored at $229 \mathrm{~nm}$ (solid line). The various peak fractions were pooled and analyzed for their Gla-content (dashed line). 
The crude plaque proteins were fractionated on a size-exclusion column using high performance liquid chromatography. The varous peak fractions were pooled as indicated in fig. 2 and analyzed for their Gla-content. Gla was mainly present in peak nr. 5 and rechromatography of this sample showed one single peak eluting at a position corresponding to a mass of approximately 20 $\mathrm{kD}$. Also analysis on polyacrylamide gels in SDS showed a single protein band with an apparent mass of $20 \mathrm{kD}$, which did not change under reducing conditions. The preparation thus obtained still strongly inhibited the in vitro precipitation of calcium salts. Its biochemical characterization is now in full progress and will shortly be reported elsewhere.

\section{DISCUSSION}

Amongst the Gla-containing proteins bound to calcified atherosclerotic plaques we have been unable to detect prothrombin, factor $\mathrm{X}$ or protein $\mathrm{C}$. Since these three proteins are the most abundant Gla-proteins in plasma we assume that adsorption of the proteins involved in blood coagulation to the calcifying vessel wall hardly occurs. Osteocalcin, on the other hand, is found in plasma in extremely low concentrations, but substantial amounts could be identified in the calcium plate extract. This observation might be explained by its low mass $(6 \mathrm{kD})$, which might facilitate its penetration into the tissue surrounding the plaque, or by its high affinity for hydroxyapatite and other calcium salts. The upper limit of the sum of free osteocalcin and that complexed to albumin was determined to be $30 \%$ of the total amount of Gla-proteins.

After removal of all osteocalcin from the sample, the remaining preparation still strongly inhibited the in vitro precipitation of calcium salts and it was made plausible that one or more Gla-proteins were responsible for this activity. Fractionation of the sample by HPLC lead to the purification of a Glacontaining protein with an apparent mass of $20 \mathrm{kD}$. Since atherocalcin is a trivial name, we will designate the $20 \mathrm{kD}$ protein we found as plaque Glaprotein.

The pathophysiological importance of the plaque Gla-protein remains a matter of speculation. Because of its strong inhibition of calcium salt precipitation in vitro, it might play a role in preventing the calcification of atheromatous plaques. If for some reason (e.g. a decreased production of plaque Glaprotein) calcification of the vessel wall does occur, the protein is expected to bind to the calcified material thus retarding the calcification process without 
preventing it. This would explain why it can be isolated from the calcified plates.

Antibodies against the purified plaque Gla-protein have been raised and were successfully used to develop an enzyme-linked immunosorbent assay (ELISA). Immunopurified antibodies will be used for the cytochemical detection and localization of plaque Gla-protein in vessel wall, whereas the ELISA will be used to measure its concentration (if any) in plasma from normal subjects and from atherosclerotic patients. These investigations are in current progress in our laboratory.

\section{ACKNOWLEDGEMENTS}

This research was supported by grant 900-526-052 from the Division for Health Research TNO. The authors wish to thank Mrs. M. Ulrich, Mrs. M. Knapen and Mr. P. van de Loo for their excellent technical assistance. We are grateful to Dr. K. Hamulyák for his constructive criticism and stimulating discussions and to Mrs. M. Molenaar-van de Voort for typing the manuscript. The authors also would like to thank the Departments of Pathology from the St. Maartensgasthuis in Venlo and the St. Jozef Hospital in Kerkrade for supplying us with human aortas.

\section{REFERENCES}

1. Van Haarlem, L.J.M., Ulrich, M.M.W., Hemker, H.C., Soute, B.A.M. and Vermeer, C. Biochem. J. 242: 251-255, 1987

2. Levy, R.J., Lian, J.B. and Gallop, P.M. Biochem. Biophys. Res. Commun. 91: 41-49, 1979

3. Levy, R.J., Howard, S.L. and Oshry, L.J. Atherosclerosis 59: 155-160, 1986

4. Vermeer, C., Soute, B.A.M., Hendrix, H. and de Boer-van den Berg, M.A.G. FEBS Lett. 165: 16-19, 1984

5. Sedmak, J.J. and Grossberg, S.E. Anal. Biochem. 79: 544-552, 1977

6. Kuwada, M. and Katayama, K. Anal. Biochem. 131: 173-179, 1983

7. Poser, J.W. and Price, P.A. J. Biol. Chem. 254: 431-436, 1979

8. Van de Loo, P.G.F., Soute, B.A.M., van Haarlem, L.J.M. and Vermeer, C. Biochem. Biophys. Res. Commun. 142: 113-119, 1987 


\section{PURIFICATION AND PARTIAL CHARACTERIZATION OF A HITHERTO UNIDENTIFIED GLA-CONTAINING PROTEIN FROM CALCIFIED HUMAN ATHEROSCLEROTIC PLAQUES}

L. Johan M. van Haarlem, Berry A.M. Soute and Cees Vermeer

\section{SUMMARY}

In this paper we describe the isolation of a 4-carboxyglutamic acid (Gla)containing protein from calcified human atherosclerotic plaques. The protein was extracted from pulverized calcified plaques by demineralization with EDTA, and subsequently purified by anion-exchange chromatography and gel filtration. The protein was designated as plaque Gla-protein (PGP) and has an apparent mass of $20 \mathrm{kD}$ as estimated from SDS-polyacrylamide gel analysis. The amino acid composition as well as the sequence analysis of the protein demonstrate that PGP is not a fragment of one of the known Gla-containing proteins circulating in blood plasma. No immunological relationship (as tested by Western blot analysis) was found between PGP and other known Glacontaining proteins. 


\section{INTRODUCTION}

Proteins containing the unusual amino acid 4-carboxyglutamic acid (Gla) have been detected in blood plasma and in a variety of calcified tissues, such as bone, dentin, renal stones and hardened atherosclerotic plaques (1-6). The only known function of the Gla-residues in these proteins is the binding of calcium ions. The Gla-containing proteins of hepatic origin have been characterized several years ago, and their role in blood coagulation is fairly well understood $(7,8)$. The function of the non-hepatic Gla-containing proteins, on the other hand, has remained obscure as yet. Most of the information available has been obtained from osteocalcin, the Gla-containing protein produced by the osteoblasts in bone tissue (9).

In 1979 it was described by Levy et al. that a Gla-containing protein could also be isolated from hardened atherosclerotic plaques, and because of its calcium-binding properties it was called atherocalcin (5). The mass of this protein was found to be $80 \mathrm{kD}$ and it was dissimilar from any of the blood coagulation factors. Recently, however, Levy et al. reported, that atherocalcin merely is a complex consisting of albumin and osteocalcin. Also trace amounts of non-bound osteocalcin $(5.8 \mathrm{kD})$ and other non-identified Gla-containing proteins $(6-8 \mathrm{kD})$ seem to occur in mineralized heart valves $(10)$ and in calcified atherosclerotic lesions (11). The origin of the latter proteins is currently unknown and it has been suggested that they are proteolytically degraded coagulation factors.

We have developed an extraction procedure by which essentially all proteins are released from the mineralized atherosclerotic plaques (12) and we have investigated if other Gla-containing proteins may be found in the extract. The results of these experiments are presented in this paper.

\section{MATERIALS AND METHODS}

\section{Materials}

Bovine serum albumin, soybean trypsin inhibitor and guanidine hydrochloride (guanidine $/ \mathrm{HCl}$ ) were obtained from Sigma (Saint Louis, USA) and CNBr-activated Sepharose 4B, QAE-Sephadex, DEAE-Sephacel as well as prepacked polyacrylamide Phast Gel gradient gels and the Low Molecular Weight protein calibration kit were products of Pharmacia (Uppsala, Sweden). Benzamidine hydrochloride was purchased from Janssen Chimica (Beerse, 
Belgium), trasylol was from Bayer (Leverkusen, FRG) and Keyhole Limpet Haemocyanin (KLH) from Pacific Bio-marine Supply Co. (California, USA). Purified human prothrombin and factor $X$ were obtained from Dr. J.W.P.H. Soons (University of Limburg), human factor IX, the proteins $\mathrm{C}, \mathrm{S}$ and $\mathrm{Z}$ as well as antibodies against the various coagulation factors were kindly supplied by Dr. R.M. Bertina (University Hospital, Leiden, The Netherlands). Human osteocalcin was purified as described by Poser et al. (13) and antibodies were raised in rabbits. All chemicals were of analytical grade or better. The Diaflo PM-50 ultrafiltration system was purchased from Amicon (Oosterhout, The Netherlands) and Spectrapor dialysis tubing from Spectrum Industries (Los Angeles, USA).

\section{Plaque Gla-protein}

Human atherosclerotic aortas were obtained at autopsy between 5 and $24 \mathrm{~h}$ after death and promptly frozen. The protocol of investigation had been approved by the University Hospital Ethical Committee. It was checked that the donors had not been treated with oral anticoagulants. For a routine preparation of plaque Gla-protein 50-60 aortas were thawed and areas of discrete calcification were carefully dissected from surrounding tissue and pooled. After extensive washing of the calcified plaques with buffer $\mathrm{A}(0.15 \mathrm{M} \mathrm{NaCl}, 50 \mathrm{mM}$ Tris/ $\mathrm{HCl}, \mathrm{pH} 8.0$ ) and a second examination to remove the last traces of tissue, a liquid nitrogen milled powder was prepared, resulting in approximately $50 \mathrm{~g}$ of powder. Proteins were extracted from the calcified material by stirring the powder in 11 of buffer B (1.0 M EDTA, $0.2 \mathrm{M} \mathrm{KCl}, 4.0 \mathrm{M}$ guanidine/ $\mathrm{HCl}, \mathrm{pH}$ $8.0,0.01 \mathrm{M}$ benzamidine $/ \mathrm{HCl}, 0.02 \% \mathrm{w} / \mathrm{v}$ soybean trypsin inhibitor and $10^{5}$ $\mathrm{U} / \mathrm{l}$ trasylol) for 4 days at $4{ }^{\circ} \mathrm{C}$. Insoluble material was collected by centrifugation at $10,000 \times \mathrm{g}$ for $15 \mathrm{~min}$ at $4 \mathrm{oC}$ and extracted for a second period of 4 days. The pooled extracts were diluted 20 fold with distilled water, adsorbed batchwise to QAE-Sephadex (10 ml of pre-swollen slurry in buffer A per 1 of diluted extract) and the adsorbed proteins were eluted with $1.0 \mathrm{M} \mathrm{NaCl}$ in buffer $\mathrm{A}$. The calcium plaque extract thus obtained was fractionated further by fast protein liquid chromatography (FPLC) on a Mono-Q anion exchange column. The proteins were applied in buffer $\mathrm{C}(20 \mathrm{mM}$ Bis-Tris/HCl, $\mathrm{pH} 7.0)$ and eluted with a linear gradient from 0 to $1 \mathrm{M} \mathrm{NaCl}$ in buffer $\mathrm{C}$. The Glacontaining fractions were pooled and fractionated further on a Superose 12 size-exclusion column using FPLC. All protein-bound Gla-residues were recovered in the protein peak eluting at a position corresponding to a mass of 20 $\mathrm{kD}$. This protein was designated as plaque Gla-protein (PGP). 


\section{Anti-PGP antibodies}

The highly immunogenic KLH was conjugated to purified PGP (3.5 mg KLH per mg PGP) according to Tanaka et al. (14). Portions containing $75 \mu \mathrm{g}$ PGP were emulsified with Freund's complete adjuvant (Difco Laboratories, Detroit, USA) and used for the immunisation of rabbits through multiple intracutaneous injections. Booster injections were given in Freund's incomplete adjuvant at three weeks intervals. Immunoglobulin $\mathrm{G}$ (IgG) was purified from the immune sera by $\left(\mathrm{NH}_{4}\right)_{2} \mathrm{SO}_{4}$ precipitation and DEAE-Sephacel column chromatography and the presence of $\operatorname{IgG}$ in the various fractions was measured with an assay based on horse radish peroxidase (HRP)-labeled swine anti-rabbit total IgG (Dako, Denmark). The proteins were subsequently concentrated in an Amicon cell using a PM-50 membrane filter. Immunoelectrophoretic analysis of the sample revealed one precipitin line, indicating that the prepation consisted of homogenous IgG.

\section{Various assays}

Polyacrylamide gel electrophoresis in the presence and absence of SDS was performed with prepacked PhastGel gradient gels (10-15\% and 8-25\% crosslinking) in combination with PhastGel SDS and native buffer strips. The gels were either stained with Coomassie Brilliant Blue or subjected to Western blotting using HRP-labeled swine anti-rabbit immunoglobulin as a second antibody.

Protein concentrations were determined as described by Sedmak and Grossberg (15). Gla and Glu residues in the various proteins were determined after alkaline hydrolysis according to Kuwada and Katayama (16). This method is based on the separation of derivatized amino acids by HPLC. The various peaks were recorded and the surface areas were integrated automatically using a Kratos Spectroflow 980 fluorescence detector. These surface areas were regarded as a measure for the Gla-concentration in the sample. A reference curve was constructed with known amounts of purified Gla and used for the quantitation of the Gla-concentration in the various samples.

The amino acid composition of PGP was established after acid hydrolysis using a LKB 4400 amino acid analyser. Amino acid sequences were determined at the Gas Phase Sequenator Facility (Department of Medical Biochemistry, University of Leiden, The Netherlands), which is supported by the Netherlands organization for the Advancement of Pure Research (ZWO) 
through the Netherlands Foundation for Chemical Research (SON). The instrument used was an Applied Biosystems Model 470A Protein Sequencer, on-line equipped with a Model 120 A PTH Analyzer

Osteocalcin was assayed with a commercial radioimmuno assay (RIA) kit (INCSTAR, Stillwater, USA).

\section{RESULTS}

A Gla-containing protein (PGP) was isolated from the calcified plaques of human aortas and the purification procedure is summarized in table I. The last two steps were anion-exchange and size-exclusion chromatography and the elution patterns are shown in fig. 1. Rechromatography of the final preparation on a Superose 12 column showed one single peak, eluting at a position of $20 \mathrm{kD}$. Purified PGP was analyzed by electrophoresis on polyacrylamide gels in SDS (fig. 2). Both, under reducing and non-reducing conditions one band was found with an $\mathrm{M}_{\mathrm{r}}$ of $20 \mathrm{kD}$. From these results we concluded that our PGP preparation was homogenous and contained a single-chain protein.

TABLE I

Purification of plaque Gla-protein from calcified human atherosclerotic plaques

\begin{tabular}{|c|c|c|c|c|}
\hline Step & $\begin{array}{l}\text { Protein } \\
(\mathrm{mg} / \mathrm{ml})\end{array}$ & $\begin{array}{l}\text { Gla } \\
(\mathrm{mM})\end{array}$ & $\underset{(\mathrm{nmol} / \mathrm{mg} \text { protein) }}{\mathrm{Gla}}$ & Purification \\
\hline $\begin{array}{l}\text { 1. Proteins released } \\
\text { after demineralisation } \\
\text { 2. QAE-Sephadex eluate } \\
\text { 3. Mono-Q Peak } \\
\text { 4. Superose-12 Peak }\end{array}$ & $\begin{array}{l}0.53 \\
7.86 \\
1.05 \\
0.60\end{array}$ & $\begin{array}{l}\text { ND* } \\
0.03 \\
0.095 \\
0.122\end{array}$ & $\begin{array}{c}\mathrm{ND}^{*} \\
4 \\
90.4 \\
203.3\end{array}$ & $\begin{array}{c}\mathrm{ND}^{*} \\
1 \\
22.6 \\
50.8\end{array}$ \\
\hline
\end{tabular}

\footnotetext{
*ND, non detectable. Protein-bound Gla-residues could not be detected because of the large excess of other proteins.

The Gla-concentration of the various samples was calculated as described in Methods.
}

The total amino acid composition of PGP was determined after acid hydrolysis and the results are summarized in table II. Gla was quantified in a separate run after alkaline hydrolysis. The $\mathrm{N}$-terminal sequence of PGP could not be established due to blockage which indicates that the protein is not related to any of the Gla-containing proteins occurring in plasma. 

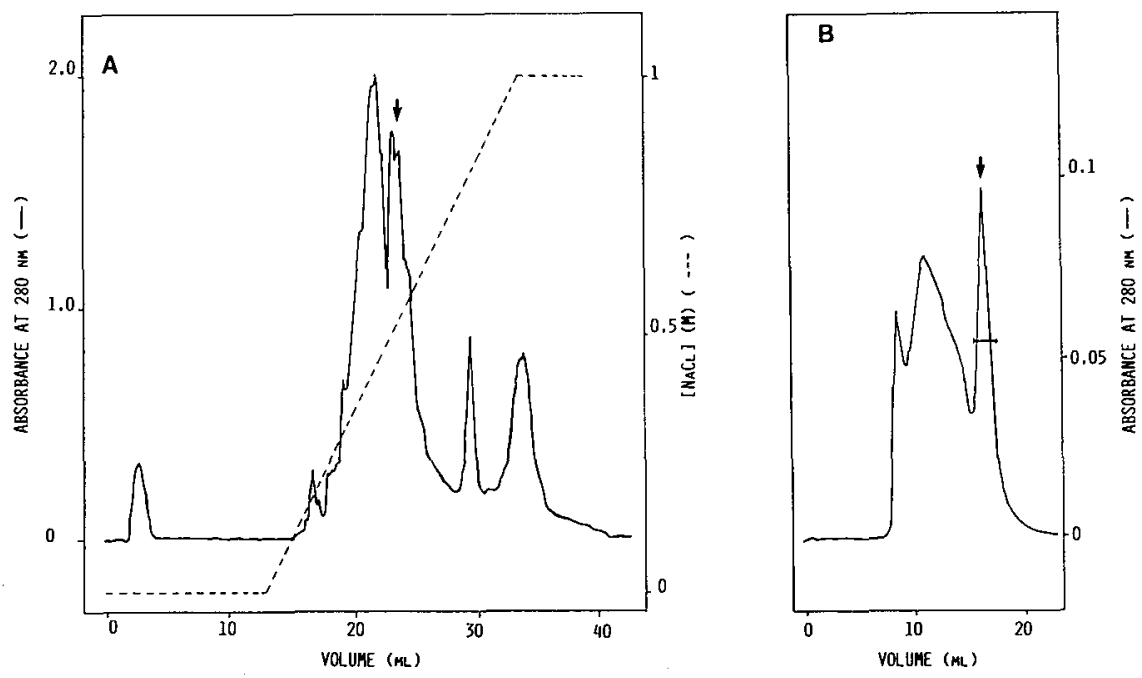

Fig. 1. Fractionation of calcium plaque extract.

A. The crude plaque proteins were applied on a Mono-Q anion-exchange column, equilibrated with $20 \mathrm{mM}$ Bis-Tris/HCl, $\mathrm{pH} 7.0$. Elution was performed with a linear gradient from 0 to $1000 \mathrm{mM} \mathrm{NaCl}$ in the same buffer and the effluent was monitored continuously at $280 \mathrm{~nm}$. Aliquots were taken from the fractions $(0.5$ $\mathrm{ml}$ ) and analyzed for their Gla-content. Gla was mainly present in the protein peak eluting at $0.53 \mathrm{M} \mathrm{NaCl}$ (arrow).

B. The Gla-containing fractions were pooled as indicated, dialyzed and applied to a Superose 12 column equilibrated with $20 \mathrm{mM}$ Bis-Tris/HCl, $50 \mathrm{mM} \mathrm{NaCl}, \mathrm{pH}$ 7.0. The effluent was monitored at $280 \mathrm{~nm}$ and the various protein fractions were analyzed for Gla. Gla was present in the protein fraction, eluting at a position corresponding to a $\mathrm{M}_{\mathrm{r}}=20 \mathrm{kD}$ (arrow). Fractions were pooled as indicated and designated as PGP.

Polyclonal antibodies against PGP were raised in rabbits and used to investigate by Western blot analysis a possible immunochemical relationship between PGP and any of the following proteins: prothrombin, osteocalcin, the blood coagulation factors VII, IX and $\mathrm{X}$ and proteins $\mathrm{C}, \mathrm{S}$ and $\mathrm{Z}$. As shown in fig. 3A only PGP was stained and none of the other proteins, even if they were loaded on the gel in a 10 -fold excess. In a complementary experiment we also checked the cross-reactivity of PGP with antibodies against each of the proteins mentioned above. Also in this case no relationship was found between PGP and prothrombin (fig. 3B), osteocalcin (fig. 3C) or one of the other proteins (data not shown). 
TABLE II

Amino acid composition of human plaque Gla-protein

\begin{tabular}{lc}
\hline Amino acid & Calculated* \\
\hline$\gamma$-Carboxyglutamic acid & $4.1^{\#}$ \\
Aspartic acid & 16.3 \\
Threonine & 9.0 \\
Serine & 14.0 \\
Glutamic acid (+Glutamine) & 17.1 \\
Proline & $\mathrm{ND}$ \\
Glycine & 30.2 \\
Alanine & 11.9 \\
Valine & 9.5 \\
Methionine & 0.8 \\
Isoleucine & 4.4 \\
Leucine & 10.0 \\
Tyrosine & 6.2 \\
Phenylalanine & 6.0 \\
Histidine & 3.2 \\
Lysine & 7.4 \\
Tryptophan & 1.3 \\
Arginine & 6.9 \\
Cystine & $\mathrm{ND}$ \\
& \\
Total residues & 158 \\
* These values are the average of duplicate 18h hydrolyses. & \\
\# Determined after alkaline hydrolysis. & \\
o ND, not determined. &
\end{tabular}

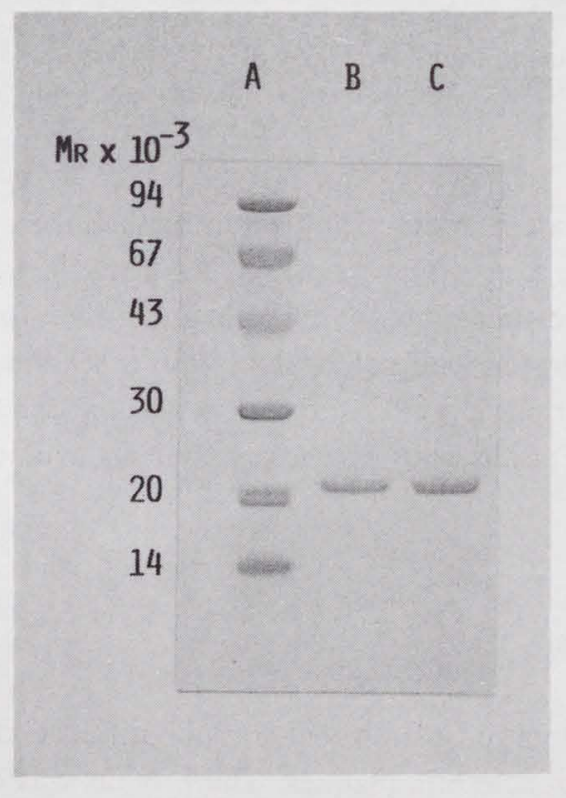

Fig. 2.

SDS-polyacrylamide gel analysis of human plaque Gla-protein.

Lane A: marker proteins, reduced; lane B: $5 \mu \mathrm{g}$ reduced purified PGP; lane C: $5 \mu \mathrm{g}$ unreduced purified PGP. 
A

B

$\begin{array}{lllll}1 & 2 & 3 & 4 & 5\end{array}$

6

78

910

11

Fig. 3. Western blot analysis of human plaque Gla-protein.

The various proteins were separated by SDS-polyacrylamide gel electrophoresis and transferred into nitrocellulose paper as described in Materials and methods. The blots were treated with either anti-PGP IgG (A), anti-prothrombin IgG (B) or antiosteocalcin IgG (C).

Lanes 1,10 and 11:5 $\mu \mathrm{g}$ osteocalcin; lanes 2 and 3: 1 and $2.5 \mu \mathrm{g}$ PGP; lanes 4,6 and 9: $5 \mu \mathrm{g}$ PGP; lanes 5,7 and 8: $10 \mu \mathrm{g}$ prothrombin.

Because of its low mass osteocalcin undergoes a rapid diffusion in polyacrylamide gels during and shortly after electrophoresis. As a result its concentration may sometimes be underestimated with this technique. Therefore we have tested purified PGP for the presence of osteocalcin with a second technique, the radioimmuno assay. Various dilutions of PGP with concentrations ranging from $5-1000 \mathrm{ng} / \mathrm{ml}$ were tested with this assay, but no osteocalcin could be detected.

\section{DISCUSSION}

In this paper we describe the isolation of a hitherto unidentified Gla-containing protein from calcified atherosclerotic plaques. The protein was called 
PGP (plaque Gla-protein) and biochemical characterization showed that it is a single chain molecule with a mass of $20 \mathrm{kD}$. The amino acid composition was determined and showed that PGP contains 4.1 Gla-residues per molecule and appreciable amounts of serine and threonine and one residue of methionine. These data exclude the possibility that PGP is somehow related to osteocalcin (which does not contain serine, threonine and methionine). From the sequence analysis of the protein it became evident that PGP is dissimilar from any of the Gla-proteins which have been characterized as yet.

Immunochemical characterization of PGP was performed by Western blot analysis and no cross reaction could be detected between PGP and antibodies against other Gla-proteins or vice versa. With the aid of a commercial RIA (lower detection limit is $1 \mathrm{ng} / \mathrm{ml}$ ) it was demonstrated that the contamination of PGP (1000 ng tested) by osteocalcin antigen is less than $0.1 \%$.

The origin of PGP is not yet known. Obviously the protein might be adsorbed from the blood stream to the calcifying vessel wall, but in that case it remains to be explained why other Gla-containing proteins, such as prothrombin, are not or hardly detectable in the calcified plaque extract. Alternatively PGP might also be synthesized by the vessel wall itself. In that respect it is at least suggestive that recently the arterial intima was detected to contain relatively high amounts of vitamin $\mathrm{K}$-dependent carboxylase, the enzyme which is required for Gla-formation $(17,18)$. Also in cultured endothelial cells of arterial and venous origin the carboxylating enzyme system could be detected (19).

Nothing is known about the in vivo function of PGP. In vitro the protein has an extreme potency to inhibit the precipitation of various calcium salts (12), but if a similar function will be its main physiological role remains a matter of speculation. Our present hypothesis is that PGP is synthesized in the vessel wall and that the continuous flow of PGP from this tissue to the blood stream is one of the means to prevent the deposition of calcium salts. If for some reason calcification does occur, PGP is obviously expected to bind to the crystal surface, since all Gla-containing proteins are known to have a high affinity for insoluble barium and calcium salts. This hypothesis implies that PGP will probably occur also in plasma. Techniques to detect PGP in plasma and to isolate it therefrom are presently developed in our laboratory.

\section{ACKNOWLEDGEMENTS}

This research was supported by grant 900-520-052 from the Division for Health Research TNO. The authors wish to thank Drs. H.C. Hemker and K. Hamulyák for their stimulating 
discussions. We are grateful to Mrs. M. Knapen for her excellent technical assistance and Mrs. M. Molenaar-van de Voort for typing this manuscript. Mr. H. van Eijck is acknowledged for analysing the amino acid mixtures. The authors would also like to thank the Departments of Pathology from the St. Maartensgasthuis in Venlo and the St. Jozef Hospital in Kerkrade for supplying us with human aortas.

\section{REFERENCES}

1 Price, P.A., Otsuka, A.S., Poser, J.W., Kristaponis, J. and Raman, N. Proc. Natl. Acad. Sci. (USA) 73: 1447-1451, 1976

2. Hauschka, P.V., Lian, J.B. and Gallop, P.M. Proc. Natl. Acad. Sci. (USA) 72: 3925 3929,1975

3. Linde, A., Bhown, M., Cothran, W.C., Högland, A. and Butler, W.T. Biochim. Biohys. Acta 704: 235-239, 1982

4. Lian, J.B., Prien, E.L., Glimcher, M.J. and Gallop, P.M. J. Clin. Invest. 59: 11511157,1977

5. Levy, R.J., Lian, J.B. and Gallop, P.M. Biochem. Biophys. Res. Commun. 91: 41-49, 1979

6. Lian, J.B., Levy, R.J., Bernhard, W. and Szycher, M. Trans. Amer. Soc. Artif. Intern. Organs 27: 683-689, 1981

7. Esmon, C.T., Sadowski, J.A. and Suttie, J.W. J. Biol. Chem. 250:4044-4748, 1975

8. Vermeer, C. Mol. Cell. Biochem. 61: 17-35, 1984

9. Nishimoto, S.K. and Price, P.A. J. Biol. Chem. 255: 6579-6583, 1980

10. Levy, R.J., Gundberg, C.M. and Scheinman, R. Atherosclerosis 46: 49-56, 1983

11. Levy, R.J., Howard, S.L. and Oshry, L.J. Atherosclerosis 59: 155-160, 1986

12. Van Haarlem, L.J.M., Soute, B.A.M., Hemker, H.C. and Vermeer, C. In: Current Advances in Vitamin K Research. (Suttie, J.W., ed.) pp. 287-292, 1988. Elsevier/North Holland, New York

13. Poser, J.W., Esch, F.S., Ling, N.C. and Price, P.A. J. Biol. Chem. 255: 8685-8691, 1980

14. Tanaka, I., Misono, K.S. and Inagami, T. Biochem. Biophys. Res. Commun. 124: 663668,1984

15. Sedmak, J.J. and Grossberg, S.E. Anal. Biochem. 79: 544-552, 1977

16. Kuwada, M. and Katayama, K. Anal. Biochem. 131: 173-179, 1983

17. Van Haarlem, L.J.M., Ulrich, M.M.W., Hemker, H.C., Soute, B.A.M. and Vermeer, C. Biochem. J. 245: 251-255, 1987

18. De Boer-van den Berg, M.A.G., van Haarlem, L.J.M. and Vermeer, C. Thrombos. Res. Suppl. VI: 135 (Abstr.), 1986

19. De Boer-van den Berg, M.A.G., Uitendaal, M.P. and Vermeer, C. Mol. Cell. Biochem. 75: 71-76, 1987 


\section{AN ELISA FOR PLAQUE GLA-PROTEIN (PGP) AND ITS DETECTION IN PLASMA}

L. Johan M. van Haarlem, Marc H. De Baets, Marjo H.J. Knapen,

K. Hamulyák and Cees Vermeer

\section{SUMMARY}

In this paper the development and application of an Enzyme-linked Immunosorbent Assay (ELISA) for plaque Gla-protein (PGP) is described. The assay is based on the sandwich technique and appeared to be specific for PGP. The sensitivity limit of the assay is $50 \mu \mathrm{g} / \mathrm{L}$ and the intra- and interassay coefficients of variation are 6.6 and $9.1 \%$, respectively. This ELISA enabled us to quantify PGP levels in blood plasma and serum. PGP values in plasma samples from 60 healthy laboratory coworkers (mean age: 35 ) varied between $0.5-1.5 \mathrm{mg} / \mathrm{L}$. It was shown that almost all plasma-PGP levels of patients suffering arterial occlusive disease and of patients receiving oral anticoagulant therapy, were below $0.1 \mathrm{mg} / \mathrm{L}$. It was also shown that apparently healthy heavy smokers had very low plasma-PGP levels. It is attractive to assume that measurement of plasma-PGP levels might be useful as a relative early marker for atherosclerotic disease. 


\section{INTRODUCTION}

Atherosclerosis is the most common disease in the Western society and the underlying cause of most cardiovascular diseases. In most patients one or more risk factors can be identified, such as hypercholesterolemia, smoking, hypertension and diabetes. Despite intensive research with regard to the pathogenesis of atherosclerosis, its mechanism is not yet known (1) and it is likely therefore, that hitherto unidentified other factors contribute.

In a previous paper (2) we have reported the presence of a hitherto unidentified protein in calcified human atherosclerotic plaques. The protein which we called plaque Gla-protein (PGP) was purified and turned out to contain four Gla-residues per molecule. Further characterization of PGP included the determination of the amino acid composition as well as the sequence analysis of the N-terminal residues and revealed that PGP is not related to any of the known Gla-containing proteins in blood plasma. PGP is a one-chain molecule with a $\mathrm{M}_{\mathrm{r}}$ of $20 \mathrm{kD}$.

Nothing is known about the origin of PGP. One possibility is that it is synthesized by the cell components of the vessel wall (either constitutively or only during the calcification process). Alternatively the protein might be synthesized elsewhere (e.g. in the liver) and subsequently be transported to the calcifying vessel wall via the blood stream. In both cases the occurrence of PGP in plasma may be expected, and it seemed worthwhile to develop an assay with which plasma samples could be screened for the presence of PGP. The technique chosen was the ELISA and the first results obtained are described in this paper.

\section{MATERIALS AND METHODS}

\section{Materials}

DEAE-Sephacel was purchased from Pharmacia (Uppsala, Sweden) and 3,3diaminobenzidine-tetrachloride (DAB) from Fluka AG (Buchs, Switzerland). Bovine serum albumin (BSA), horse radish peroxidase (HRP) grade VI and 0phenylene diamine (OPD) were obtained from Sigma (St. Louis, USA). All other chemicals were from Merck (Darmstadt, FRG) and were of analytical grade or better. Polyvinylchloride microtiter plates containing 96 wells were from Titertek (Amsterdam, The Netherlands). 


\section{Proteins}

PGP was purified from calcified human atherosclerotic plaques as described earlier (2). Human osteocalcin was prepared according to Poser et al. (3). Purified human prothrombin and coagulation factor $\mathrm{X}$ were gifts from Dr. J.W.P.H. Soons (University of Limburg), the human coagulation factors VII and IX as well as the proteins $\mathrm{C}, \mathrm{S}$ and $\mathrm{Z}$ were generously supplied by $\mathrm{Dr}$. R.M. Bertina (University Hospital, Leiden, The Netherlands). Polyclonal antibodies against PGP were raised in rabbits and the immunoglobulin G (IgG) fraction was purified from the immune serum as described in (2). The IgG antibodies were concentrated to $5 \mathrm{mg} / \mathrm{mL}$ and conjugated with HRP according to Nakane and Kawaoi (4). Aliquots $(0.05 \mathrm{ml})$ of the conjugated material were kept frozen at -80 oC until use.

\section{Blood handling}

Blood was taken by venepuncture and either collected in disodium citrate (final concentration: $13 \mathrm{mM}$ ) or used for the preparation of serum. On some occasions the blood was also collected in either heparin (4 $\mathrm{U} / \mathrm{mL})$ or EDTA (1 $\mathrm{mg} / \mathrm{mL}$ ). After centrifugation at $1900 \times \mathrm{g}$ for $15 \mathrm{~min}$ the supernatant plasma was collected, divided into $0.2 \mathrm{ml}$ aliquots and stored immediately at $-80 \mathrm{\circ} \mathrm{C}$ until use.

\section{PGP-assay}

The technique developed was an ELISA based on the double antibody sandwich technique (5). Microtiter plates were filled with $0.05 \mathrm{ml}$ anti-PGP $\operatorname{IgG}$, which had been diluted to $15 \mu \mathrm{g} / \mathrm{ml}$ with buffer $\mathrm{A}\left(0.1 \mathrm{M} \mathrm{NaHCO}_{3} / \mathrm{Na}_{2} \mathrm{CO}_{3}\right.$, $\mathrm{pH}$ 9.6). Coating was completed by incubating the plates for $16 \mathrm{~h}$ at room temperature. Subsequently the plates were washed three times with buffer B (137 mM NaCl, $2.7 \mathrm{mM} \mathrm{KCl}, 1.5 \mathrm{mM} \mathrm{KH}_{2} \mathrm{PO}_{4}, 8.1 \mathrm{mM} \mathrm{Na}_{2} \mathrm{HPO}_{4}$, pH 7.4, $0.5 \%(\mathrm{v} / \mathrm{v})$ Tween-20 and $0.1 \%(\mathrm{w} / \mathrm{v}) \mathrm{BSA}$ ). Serial dilutions of purified PGP and plasma samples were prepared in buffer $\mathrm{C}(137 \mathrm{mM} \mathrm{NaCl}, 2.7 \mathrm{mM} \mathrm{KCl}$, $1.5 \mathrm{mM} \mathrm{KH}_{2} \mathrm{PO}_{4}, 8.1 \mathrm{mM} \mathrm{Na}_{2} \mathrm{HPO}_{4}, \mathrm{pH} 7.4,1 \%$ (w/v) BSA). All plasma samples had been freshly frozen and were centrifuged for $2 \mathrm{~min}$ at $1900 \mathrm{x} \mathrm{g}$ shortly before use. After an incubation period of $18 \mathrm{~h}$ at $4{ }^{\circ} \mathrm{C}$ the plates were washed again three times with buffer $B$ and the wells were filled with peroxidase-conjugated anti-PGP IgG $(0.05 \mathrm{ml}$, diluted to $12.5 \mu \mathrm{g} / \mathrm{ml}$ with buffer $\mathrm{C})$. Next, the plates were incubated for $1 \mathrm{~h}$ at $37{ }^{\circ} \mathrm{C}$, washed three times with 
buffer $B$ and the wells were filled with $0.1 \mathrm{ml}$ of a solution of $0.04 \%(\mathrm{w} / \mathrm{v})$ OPD and $0.015 \%(\mathrm{v} / \mathrm{v})$ hydrogen peroxide in buffer C. Staining was performed by incubating the plates for $30 \mathrm{~min}$ at room temperature in the dark and the reaction was stopped by adding $50 \mu 14 \mathrm{~N} \mathrm{H}_{2} \mathrm{SO}_{4}$. The adsorbance (A) was read with a Titertek multiscan (Amsterdam, The Netherlands) at $492 \mathrm{~nm}$ and blanc values (buffer $\mathrm{C}$ instead of sample dilution) were subtracted.

\section{Various assays}

Protein concentrations were measured as described by Sedmak and Grossberg (6). Protein-bound Gla-residues were determined after alkaline hydrolysis according to Kuwada and Katayama (7). Statistical analyses were performed using a student's t-test.

\section{RESULTS}

\section{A. Validation of the PGP-assay.}

Serial dilutions of highly purified PGP were tested with the ELISA described in Materials and methods and a semi-logarithmic dose-response curve was constructed (fig. 1). A typical sigmoid curve was obtained with a linear part between 0.05 and $5 \mathrm{mg} / \mathrm{L}$. This curve was used as a standard curve for samples containing unknown concentrations of PGP and $50 \mu \mathrm{g} / \mathrm{L}$ was regarded as the lower detection limit in the assay.

In a similar way as described in fig. 1 dilution curves were prepared of pooled normal human plasma and serum, and of Ba-citrate extracted plasma. Because Gla-residues have a high affinity for $\mathrm{Ca}^{2+}$, Gla-containing proteins are readily adsorbed onto insoluble barium and calcium salts. Hence the extraction with these salts is a well known technique to deplete plasma from its Gla-containing proteins. As can be seen in fig. 2 detectable and similar amounts of PGP were present in plasma and in serum, but not in Ba-citrate extracted plasma.

The specificity of the ELISA was explored further by testing the immunoreactivity of albumin and the following Gla-containing plasma proteins: prothrombin, prothrombin fragment-1, the coagulation factors VII, IX and X, the proteins $\mathrm{C}, \mathrm{S}$ and $\mathrm{Z}$ and osteocalcin. All proteins were tested in serial dilutions ranging from 5 to $0.1 \mathrm{x}$ their physiological concentration, except osteocalcin, which was tested in concentrations between 5 and $1000 \mu \mathrm{g} / \mathrm{L}$. In none of the 


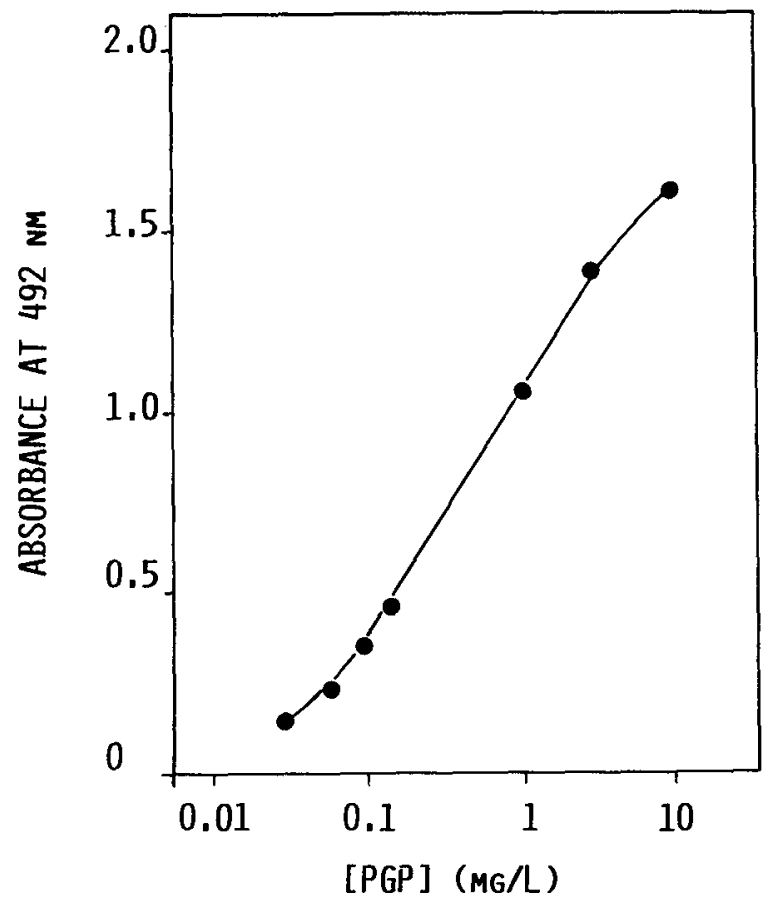

Fig. 1. Standard curve for PGP.

The conditions for the assay are described in Materials and methods. Each point represents the mean of duplicate measurements.

cases any cross-reactivity with PGP could be detected (data not shown). From these experiments we have concluded that with the newly developed ELISA PGP is specifically detected in normal human plasma and serum. The dilution curves were parallel with those obtained for purified PGP. The latter curves may thus be used as reference curves for unknown plasma samples.

PGP was determined in individual plasma samples from 60 healthy nonsmoking laboratory coworkers (25-50 years old) and its concentration amounted to $1.0 \pm 0.5 \mathrm{mg} / \mathrm{L}$ (mean $\pm \mathrm{SD}$ ). A normal pool was constituted from the same subjects and used for further validation of the assay. The intraassay coefficient of variation was determined by measuring the immune response of 12 similar sets of normal plasma dilutions, assayed in one microtiter plate, and it was found to be $6.6 \%$. The interassay coefficient of variation was tested on 3 subsequent days and was found to be $9.1 \%$. No differences of assay values were observed between blood samples taken on either heparin, EDTA or citrate. 


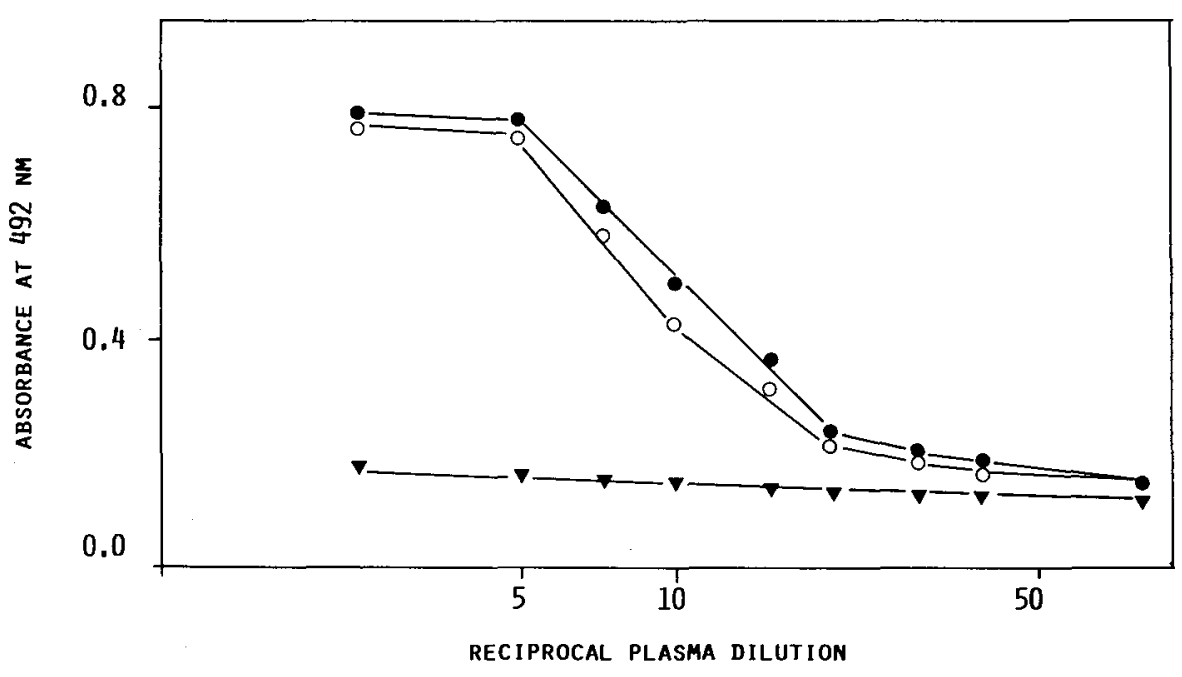

Fig. 2. Dose-response curves of human plasma (0-0), serum (O-O) and Bacitrate extracted plasma $(\nabla-\nabla-)$.

The stability of PGP in plasma samples was measured at various temperatures. At $-80^{\circ} \mathrm{C}$ and $-30^{\circ} \mathrm{C}$ PGP levels remained constant for at least 12 months, but repeated freezing and thawing caused a considerable decrease in PGP values. PGP levels also remained constant after $72 \mathrm{~h}$ at $4{ }^{\circ} \mathrm{C}$ and $24 \mathrm{~h}$ at $25^{\circ} \mathrm{C}$, but at $56^{\circ} \mathrm{C}$ its immunoreactivity was rapidly destroyed. These results made us decide to exclusively use fresh frozen plasma samples for the investigations described in the rest of this paper.

\section{B. Clinical evaluation of the PGP-assay.}

Plasma-PGP levels were measured in three different groups of subjects: I, patients with symptoms of arterial occlusive disease; II, patients on long-term oral anticoagulant therapy and III, apparently healthy cigarette smokers. In all cases the age of the subjects was between 25 and 50 years, which is comparable to that of the "normals" described in this paper. The first group consisted of young adults suffering arterial occlusive disease $(n=37,28$ males and 9 females). 


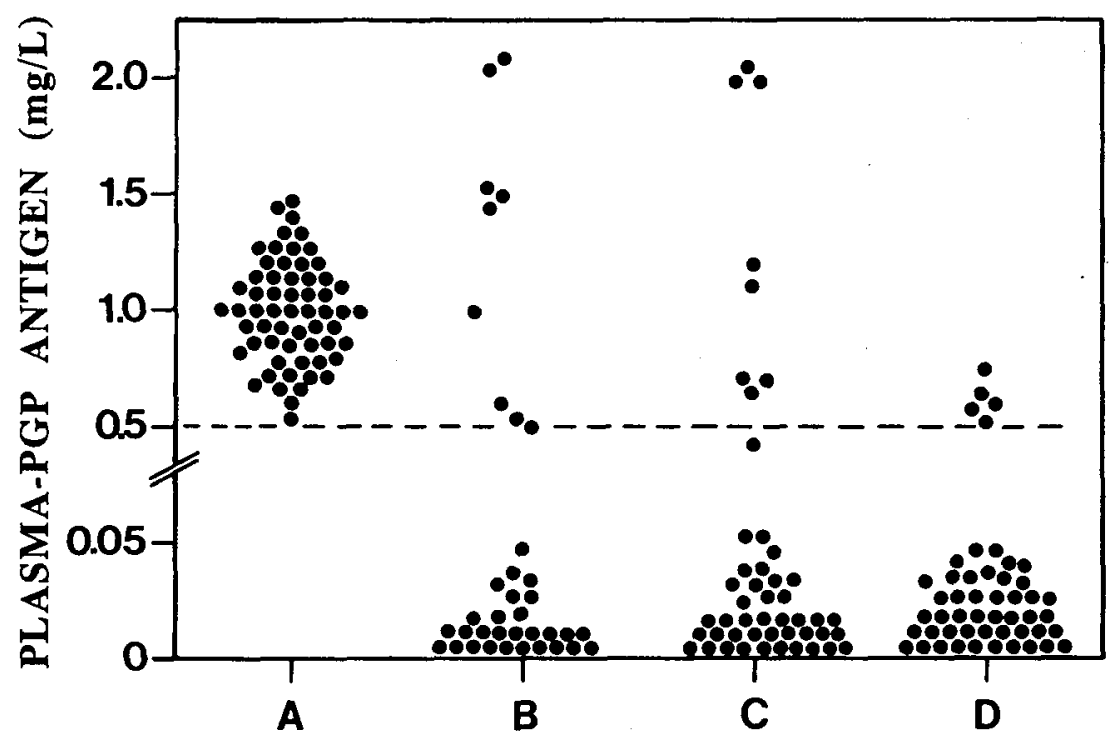

Fig. 3. Plasma-PGP levels in four different groups of subjects:

$A$, normal reference group $(n=60) ; B$, patients suffering arterial occlusive disease $(n=37) ; C$, patients on long-term oral anticoagulant therapy $(n=48)$ and $D$, apparently healthy cigarette smokers $(n=51)$.

As shown in fig. 3 the plasma-PGP levels in most patients were far below the normal range, and the difference was statistically significant $(p<0.001)$.

The second group of patients was recruited from the Trombosis Service Maastricht. They were on long-term stable oral anticoagulant therapy (i.e.: for a continuous period of more than one year, thrombotes values between 5 and $15 \%$ ) in order to prevent myocardial reinfarction. In this group, consisting of 48 patients, 39 subjects $(81 \%)$ showed PGP levels below $0.1 \mathrm{mg} / \mathrm{L}$. Three subjects with high plasma-PGP concentrations were analyzed further and turned out to have renal insufficiency. All other subjects had a normal renal function. If -like osteocalcin- PGP is cleared from plasma by the kidney, the high plasma-PGP levels might quite well be explained by an impaired excretion rather than by an increased synthesis. This possibility is currently evaluated at our laboratory. On the other hand, the mean PGP level in all subjects receiving oral anticoagulant treatment was significantly below normal $(\mathrm{p}<0.001)$. 
The third group consisted of apparently healthy cigarette smokers, with a consumption of more than 30 cigarettes daily during a continuous period of at least five years. In a group of 51 subjects only five had normal plasma-PGP levels $(0.5 \mathrm{mg} / \mathrm{L})$, nine were between 50 and $100 \mu \mathrm{g} / \mathrm{L}$ and 37 were below the detection limit (see fig. 3).

\section{DISCUSSION}

PGP is a protein of unknown function which has been isolated and purified from calcified atherosclerotic plaques (2). Here we report the development of a sensitive and specific assay with which PGP could be detected in normal blood plasma and in serum. Its concentration ranged from $0.5-1.5 \mathrm{mg} / \mathrm{L}$. In vitro it has been shown that PGP is able to prevent the precipitation of calcium phosphate and calcium carbonate from supersaturated solutions, even if these salts are present in a ten to twenty thousand fold molar excess (8). It is at least suggestive that this is quite close to the ratio between the physiological concentrations of $\mathrm{Ca}^{2+}(2 \mathrm{mM})$ and PGP $(25-75 \mathrm{nM})$. On the other hand, if precipitates of insoluble calcium salts have already formed, PGP is readily adsorbed to the mineral without dissolving it. Such a dual function is not uncommon for Gla-containing proteins (9) or other negatively charged macromolecules (10).

To find out if the PGP-assay may prove to be of clinical importance, we have started to screen the plasma-PGP levels in a number of well characterized subjects, and the first results are summarized in fig. 3. A first group of subjects consisted of young patients suffering arterial occlusive disease. These patients had an onset of symptoms of atherosclerotic peripheral vascular disease before the age of 45 years (11). It turned out that the mean plasma-PGP level of this group was less than $10 \%$ of normal.

Our working hypothesis is that -like in vitro- also in vivo PGP is somehow involved in the prevention of calcification of the atherosclerotic lesion. Like all Gla-containing proteins PGP has a high affinity for calcium phosphate and calcium carbonate crystals, which are the main constituents of the mineralized tissue. If for some reason calcification of the vessel wall does occur, the protein is expected to bind to the calcified material thus retarding the calcification process without preventing it. This process will probably further decrease the plasma-PGP levels.

The second group of subjects consisted of patients on long-term oral anticoagulant treatment. The PGP levels in most plasma samples were far below normal, but presently it is not clear if this low level is found because coumarin 
derivatives affect the production of PGP or is related to the underlying disease. This point is still a matter of research in our laboratory.

Although it seems that atherosclerotic patients can be identified by measuring their plasma-PGP levels, the assay would substantially gain in clinical importance if it could be used for the detection of atherosclerosis in an early stage of the disease. In a first attempt to investigate this possibility we have selected a group of apparently healthy heavy smokers (group III). It is wellknown that these subjects belong to a high risk group for developing atherosclerosis. It tumed out that also in this group $(n=51)$ very low plasmaPGP levels were found. The difference with an age-matched control group of non-smokers was highly significant $(\mathrm{p}<0.001)$. It remains to be established, however, if this significant correlation may be translated into the development of (symptomatic) atherosclerotic disease. A more elaborate survey, including the screening of other high risk groups (e.g. diabetes mellitus, high blood pressure, etc.) and prospective and retrospective investigations are in current progress, however.

\section{ACKNOWLEDGEMENTS}

This research was supported by grant 900-520-052 from the Division for Health Research TNO and grant $86.028 \mathrm{~h}$ from the Dutch Heart Foundation. The authors wish to thank Dr H.C. Hemker for his suggestions and stimulating discussions and Mrs. M. Molenaar-van de Voort for typing this manuscript. The authors also would like to thank Drs. E.J.P. Brommer and J.H. v. Bockel for supplying us with patient plasma samples.

\section{REFERENCES}

1. Gordon, T., Garcia-Palmieri, M.R., Kagan, A., Kannel, W.B. and Schiffman, J.J. Cronic. Dis. 27:329-344, 1984

2. This thesis, chapter 4B

3. Poser, J.W., Esch, F.S., Ling, N.C. and Price, P.A. J. Biol. Chem. 255:8685-8691, 1980

4. Nakane, P.K. and Kawaoi, A.J. Histochem. Cytochem. 22: 1084-1091, 1974

5. Voller, A., Bidwell, D.E. and Bartlett, A. WHO Bull. 53: 55-65, 1976

6. Sedmak, J.J. and Grossberg, S.E. Anal. Biochem. 79: 544-552, 1977

7. Kuwada, M. and Katayama, K. Anal. Biochem. 131: 171-179, 1983

8. Van Haarlem, L.J.M., Soute, B.A.M., Hemker, H.C. and Vermeer, C. In: Current Advances in Vitamin K Research (Suttie, J.W., ed.) pp. 287-292, 1988. Elsevier/North Holland, New York

9. Price, P.A., Otsuka, A.S., Poser, J.W., Kristaponis, J. and Raman, N. Proc. Natl. Acad. Sci. (USA) 73: 1447-1451, 1976

10. Wheeler, A.P., George, J.W. and Evans, C.A. Science 212: 1397-1398, 1981

11. Aronson, D.C., Ruys, Th., van Bockel, J.H., Briët, E., Brommer, E.J.P., Gevers Leuven, J.A., Kempen, H.J.M., Feuth, J.D.M. and Giesberts, M.A.H. Europ. J. Vasc. Surg., 1989. In press. 
128 


\section{CHAPTER 5}

\section{SUMMARY AND GENERAL DISCUSSION}

Vitamin $\mathrm{K}$-dependent carboxylase is an enzyme system found in many different types of mammalian tissues. In earlier work from this group some properties of carboxylase from liver, spleen, kidney, lung and testis have been described. In the first part of this thesis we describe the isolation of vessel wall carboxylase and the properties of this enzyme are compared with those characterized earlier. Because rather large amounts of fresh tissue were required, this part of our study was performed with bovine material, obtained from the slaughterhouse. The substrate recognition by these carboxylases was investigated by using different substrates. In a first attempt we have compared d-osteocalcins from various species. The substrates chosen for this experiment varied only slightly in their amino acid composition. Bovine d-osteocalcin turned out to be the best substrate whereas monkey d-osteocalcin was not carboxylated at all. The only difference between the two proteins is found at positions 3 and 4 , which are of opposite charge in the bovine substrate but neutral in the monkey one. Apparently the occurrence of two amino acids of opposite charge at a position of about 15 residues before the first carboxylatable Glu-residue is one of the requirements for an efficient enzyme/substrate recognition. It is at least suggestive in this respect that these oppositely charged amino acid residues are found in almost all leader sequences of other Gla-containing proteins, including those involved in blood coagulation. The high preference for bovine dosteocalcin was found in all tissues investigated, so that in this way no difference in substrate specificity between the various carboxylases could be detected, however. Another approach was to compare widely different types of substrate: F L E E L, d-osteocalcin, d-prothrombin fragment 13-29 and dsperm Gla-protein. Substantial differences were found, and it was remarkable that in vessel wall carboxylase we have found for the first time a difference which was absolute: F L E E L and (bovine) d-osteocalcin were normally carboxylated, whereas d-sperm Gla-protein and d-prothrombin fragment 1329 were not carboxylated at all.

One of the problems unsolved as yet is that of the identity of the physiological cofactor providing the reducing equivalents in the two reduction steps of the vitamin $\mathrm{K}$ cycle. In vitro synthetic dithiols such as DTT may be used, but despite more than 10 years research their physiological counterpart has never been found. In chapter $2 \mathrm{C}$ we describe that the NADPH-dependent thio- 
redoxin/thioredoxin reductase system may replace DTT with a high efficiency. Thioredoxin is a dithiol protein which is found in many organisms (from E.coli to mammals) and tissues, including calf liver. It is involved in many cellular reduction reactions, for instance in DNA synthesis, and it seems at least plausible that the protein is also involved in vitamin $\mathrm{K}$ metabolism. A practical application of our discovery is that it opens up the possibility to carboxylate proteins in vitro without employing highly reducing conditions (50 $\mu \mathrm{M}$ thioredoxin instead of $2 \mathrm{mM}$ DTT). It may be expected that disulfide bonds will remain preserved in this way, so that the reaction product remains intact. Obviously this is a prerequisite for the carboxylation of enzymatically active proteins like recombinant factor IX.

As was to be expected, the investigations conceming vessel wall carboxylase have not revealed information about the identity of the product formed. Since all Gla-containing proteins have a high affinity for insoluble $\mathrm{Ca}^{2}{ }^{2}$-salts, it seemed probable that the product of vessel wall carboxylase would be found amongst the proteins adsorbed to the calcified atherosclerotic lesions which are frequently found in human aorta's. In the second part of this thesis we have focussed our attention therefore on the Gla-containing proteins present in atherosclerotic plaques. Because atherosclerosis is relatively rare in animals this part of our study is performed exclusively with human tissue. The calcified plaques were extruded from the vessel wall and dissolved in EDTA. Two Gla-containing proteins were detected: osteocalcin and PGP. In chapter 3 we describe the development of a number of techniques required for the investigation of the structure and properties of these two proteins. Because it was readily available in sufficient amounts, osteocalcin was taken as a model protein in these studies. It was demonstrated that Gla-containing proteins differing as much as coagulation factor $\mathrm{X}$ and osteocalcin similarly inhibit the precipitation of $\mathrm{Ca}^{2+}$-salts. A maximal effect is seen at slightly acidic conditions ( $\mathrm{pH} 6$ 6.5). In this respect PGP is very different from the other Gla-containing proteins, because even at $\mathrm{pH} 7.4$ it has an extremely high potency to inhibit the precipitation of calcium phosphate and carbonate from supersaturated solutions. It was also shown that Gla-residues were absolutely required for the precipitation-inhibitory activity, and that Gla-proteins inhibit the precipitation of other divalent metal ions as well. The slight differences observed may probably be attributed to the different solubility products of these salts, rather than to other factors such as the radius of the metal ions. In chapter 3B we describe the development of an assay procedure for determining the amount of Gla-residues in circulating osteocalcin. The method is applicable for osteocalcin as well as for PGP, but as a drawback it is time consuming, so that for series of plasma or serum samples a semi-quantitative determination of Gla-residues is preferable. The latter technique is based on the affinity of Glacontaining proteins for hydroxyapatite and is used in chapter $3 \mathrm{C}$ in which we show that coumarin derivatives induce a marked decrease (more than 50\%) in serum osteocalcin antigen as well as in its Gla-content. With these data the first proof is given that oral anticoagulant therapy directly interferes with the production of a non-hepatic protein in man. Using the sheep as an experimental animal, it was also demonstrated that the effect of vitamin $\mathrm{K}$ antagonists on the 
synthesis of osteocalcin cannot be counteracted by the administration of pharmacological doses of vitamin $\mathrm{K}$ which were sufficient to normalize the production of blood coagulation factors. Lateron this phenomenon could be explained by other members of our group, who showed that the coumarininsensitive NADH-dependent vitamin $\mathrm{K}$ reductase is lacking in osteoblasts, the place of synthesis of osteocalcin.

In chapter 4 we describe the purification and properties of the second Glacontaining protein found in calcified atherosclerotic plaques. The protein was discovered after it tumed out that a calcium plaque extract contained a Glaprotein which was not immunologically related to any of the known Gla-proteins found in plasma and which seemed to inhibit strongly the precipitation of calcium phosphate and carbonate (4A). After its complete purification (4B) the protein (which was called PGP) was characterized and from its amino acid composition and blocked $\mathrm{N}$-terminus it could be demonstrated unequivocally that PGP was a new and unique protein and not, for instance, a degradation product of one of the coagulation factors. As yet the origin of PGP is unknown. One possibility is that it is synthesized by the vessel wall (either constitutively or only during the calcification process). Alternatively the protein might be produced elsewhere and subsequently be transported to the calcifying vessel wall via the blood stream. In both cases the occurrence of PGP in plasma may be expected. Hence we have developed an assay with which plasma samples can be screened for the presence of PGP (chapter 4C). The assay is based on the principle of the "sandwich ELISA" and enabled us to detect immunoreactive PGP in normal blood plasma and in serum. The concentration ranged from 0.5 to $1.5 \mathrm{mg} / \mathrm{L}$. In a first attempt to explore if the PGP-assay may also become of clinical importance, we have measured the plasma-PGP levels in 37 patients suffering from severe atherosclerosis. The mean level was found to be less than $10 \%$ of normal. In our opinion these data are promising and justify more elaborate investigations. Plans have been made for (i) a careful analysis of risk factors and plasma-PGP levels of patients requiring coronary bypass surgery (ii) a continuation of the screening of atherosclerotic patients, especially those with underlying diseases such as homocystinuria, hypercholesterolemia and diabetes mellitus. Obviously the PGP-assay would substantially gain in clinical importance if it could be used for the detection of atherosclerosis at an early stage of the disease. To answer this question, apparently healthy members of high risk groups (heavy smokers, diabetes mellitus, high blood pressure, high cholesterol, familial disorders) will have to be screened. A first exploration of this field is described in chapter $4 \mathrm{C}$, where we have measured the plasma-PGP levels in 51 heavy smokers. It is at least highly suggestive that again the plasma-PGP levels in most subjects were at least 10 -fold below normal. It is hoped that the plasmaPGP level may be used as an early marker, long before atherosclerotic degenerations become manifest otherwise. In the early phase of the disease preventive measures (elimination of risk factors, therapeutic intervention) may be expected to have a maximal effect. The tools for these investigations have been described in this thesis, but their large-scale application remains to be awaited. 


\section{SAMENVATTING}

De aanwezigheid van vitamine $\mathrm{K}$-afhankelijk carboxylase aktiviteit is in een groot aantal verschillende soorten weefsels vastgesteld. Reeds eerder heeft onze groep enkele eigenschappen van het lever-, nier-, milt-, long- en testiscarboxylase beschreven. In het eerste gedeelte van dit proefschrift wordt de isolatie en karakterisering van het vaatwandcarboxylase beschreven en worden de eigenschappen van dit enzymsysteem vergeleken met die van de eerder genoemde carboxylases. Tijdens dit deel van ons onderzoek werd gebruik gemaakt van runder materiaal afkomstig van het slachthuis. Tevens hebben we de substraat-selektie van deze carboxylases bestudeerd. In een eerste poging hiertoe hebben we osteocalcines van verschillende species geïsoleerd, gedecarboxyleerd en hun kinetische konstanten gemeten. Osteocalcine is in de evolutie merkwaardig goed geconserveerd gebleven: de verschillen tussen diverse species bedragen meestal maar 1 of 2 aminozuren. Het gedecarboxyleerd runderosteocalcine bleek het beste substraat te zijn, terwijl het gedecarboxyleerde osteocalcine uit de aap in het geheel niet gecarboxyleerd werd. Deze twee osteocalcines verschillen alleen in de aminozuur residuen in de posities 3 en 4. De lading van deze twee residuen is in het rundersubstraat tegengesteld, maar in het substraat van de aap neutraal. Klaarblijkelijk is het vóórkomen van twee tegengesteld geladen aminozuren ca. 15 residuen voor het eerste Glaresidu van belang bij de enzym-substraat herkenning. In dit verband is het op zijn minst opmerkelijk, dat deze tegengesteld geladen aminozuur residuen in bijna alle prosequenties van andere plasma Gla-bevattende eiwitten gevonden worden. In alle bestudeerde weefsels bleek er een grote voorkeur voor het rundersubstraat te bestaan. Een verschil in substraatspecificiteit tussen de verscheidene carboxylases kon op deze wijze dan ook niet aangetoond worden. Vandaar dat we hebben besloten om substraten te vergelijken die onderling sterk verschillen: F L E E L, gedecarboxyleerd osteocalcine, gedecarboxyleerd prothromine fragment 13-29 (een proteolytisch degradatieprodukt van descarboxyprothrombine) en gedecarboxyleerd sperm Gla-eiwit. Aanzienlijke verschillen werden gevonden in de herkenning van de verschillende substraten en het was opmerkelijk dat in vaatwandcarboxylase voor het eerst een absoluut verschil in substraatspecificiteit werd gevonden: F L E E L en het gedecarboxyleerde runderosteocalcine werden normaal gecarboxyleerd maar gedecarboxyleerd sperm Gla-eiwit en gedecarboxyleerd prothrombine fragment 13-29 werden in het geheel niet gecarboxyleerd. 
Vitamine $\mathrm{K}$ kan vóórkomen in verschillende vormen: het quinon $(\mathrm{K})$, het gereduceerde hydroquinon $\left(\mathrm{KH}_{2}\right)$ en het geoxydeerde epoxide (KO). Deze 3 vormen zijn alle aangetoond in de lever en men neemt aan, dat ze op cyclische wijze in elkaar worden omgezet: de vitamine $\mathrm{K}$-cyclus. In vitro kan vitamine $\mathrm{K}$ door reductases tot vitamine $\mathrm{K}$ hydroquinone gereduceerd worden. Een van deze reductases wordt in vitro door dithiothreitol (DTT) gestimuleerd; de andere worden door NADH gestimuleerd. Tijdens de carboxylering wordt vitamine $\mathrm{K}$ hydroquinon omgezet in vitamine $\mathrm{K} 2,3$ epoxide; dit wordt vervolgens door DTT-afhankelijk vitamine $\mathrm{K}$ epoxide reductase gereduceerd tot vitamin $\mathrm{K}$. De fysiologische tegenhanger van DTT in genoemde reakties is niet bekend. In hoofdstuk $2 \mathrm{C}$ staat beschreven dat in vitro het NADPH-afhankelijk thioredoxin/thioredoxin reductase systeem DTT kan vervangen. Thioredoxin, een dithiol eiwit, is aanwezig in talrijke organismen (van E.coli tot zoogdieren) en weefsels. Het is betrokken bij een groot aantal cellulaire reductie reacties (b.v. in DNA synthese) en tevens lijkt het erop dat het eiwit tevens betrokken is in het vitamine $\mathrm{K}$ metabolisme. Een praktische toepassing van deze bevinding is dat op deze wijze wellicht eiwitten in vitro gecarboxyleerd kunnen worden onder geringe reducerende condities $(50 \mu \mathrm{M}$ thioredoxin in plaats van $2 \mathrm{mM}$ DTT). Daar op deze wijze de S-S bruggen gesloten zullen blijven, blijft het reactieprodukt intact. Het is duidelijk, dat dit een eerste vereiste is voor de carboxylering van biologisch aktieve eiwitten, (zoals recombinant factor IX).

Het onderzoek betreffende het vaatwandcarboxylase heeft geen informatie opgeleverd over het eiwit dat door vaatwandcarboxylase gevormd wordt. Daar het bekend is, dat alle Gla-bevattende eiwitten een hoge affiniteit voor onoplosbare calciumzouten hebben, lijkt het waarschijnlijk dat het produkt van vaatwandcarboxylase deel uit maakt van de eiwitten, die geadsorbeerd zijn aan verkalkte atherosclerotische lesies.

In het tweede deel van dit proefschrift hebben we daarom onze aandacht gericht op de Gla-bevattende eiwitten van atherosclerotische plaques. Verkalkte humane plaques werden vrij geprepareerd uit de vaatwand en vervolgens opgelost in EDTA. Het EDTA-extract bleek twee Gla-eiwitten te bevatten: osteocalcine en PGP. In hoofdstuk 3 staat de ontwikkeling van een aantal tests centraal. Deze tests zijn noodzakelijk voor het onderzoek naar de struktuur en eigenschappen van deze twee eiwitten.

Daar osteocalcine in een behoorlijke hoeveelheid beschikbaar was, hebben we dit Gla-eiwit als modeleiwit gekozen voor de studies beschreven in hoofdstuk 3. Er werd aangetoond dat Gla-eiwitten die zeer sterk verschillen de precipitatie van calcium zouten in gelijke mate remmen. Een verklaring voor 
de waargenomen geringe verschillen kan waarschijnlijk eerder gezocht worden in een verschil in oplosbaarheidsprodukt van deze zouten dan b.v. in de straal van het metaalion. Een maximaal effekt is waarneembaar bij een $\mathrm{pH}$ van 6-6.5. In dit opzicht verschilt PGP aanzienlijk van de andere Gla-bevattende eiwitten omdat zelfs bij een $\mathrm{pH}$ van 7.4 dit eiwit in staat is de precipitatie van calciumcarbonaat en calciumfosfaat te remmen. De aanwezigheid van Gla-residuen bleek belangrijk te zijn voor de remmende aktiviteit; tevens waren deze Glaeiwitten in staat de precipitatie van andere divalente metaalionen eveneens te remmen.

In hoofdstuk 3B hebben we een test ontwikkeld om het Gla-gehalte van het circulerend osteocalcine vast te stellen. Deze methode is geschik om de carboxyleringsgraad van zowel osteocalcine als PGP te bepalen. Echter, de uitvoering van deze bepaling neemt veel tijd in beslag, zodat voor een serie van plasma of serum monsters de voorkeur gegeven wordt aan een semi-kwantitatieve bepaling van de Gla-residuen. Deze test, gebaseerd op de affiniteit van de Gla-bevattende eiwitten voor hydroxyapatite, wordt gebruikt in hoofdstuk 3C. In dit hoofdstuk laten wij zien dat coumarine derivaten een aanzienlijke afname (groter dan 30\%) in zowel antigeen als Gla-gehalte van het serumosteocalcine teweeg brengen. De verkregen resultaten van dit onderzoek vormen een eerste bewijs dat orale antistollingstherapie bij de mens direkt interfereert met de produktie van een niet-hepatisch eiwit. In een experimenteel diermodel (het schaap), kon het effekt van vitamine $\mathrm{K}$ antagonisten op de osteocalcine synthese niet opgeheven worden door het toedienen van farmacologische doses vitamine $\mathrm{K}$, welke voldoende waren om de produktie van biologisch aktieve stollingsfaktoren te normaliseren. Deze bevinding werd in een later stadium door andere leden van onze groep verklaard.Zij toonden nl. aan, dat het coumarine ongevoelige $\mathrm{NADH}$-afhankelijk vitamine $\mathrm{K}$ reductase ontbreekt in de osteoblasten (de plaats van synthese van osteocalcine).

In hoofdstuk 4 wordt de zuivering en karakterisering van een nieuw Glabevattend eiwit beschreven. Een EDTA-extract van verkalkte humane atherosclerotische plaques bleek een Gla-eiwit te bevatten, dat immunologisch niet verwant is aan een van de bekende plasma Gla-eiwitten. Tevens was dit eiwit in staat de precipitatie van calciumfosfaat en calciumcarbonaat sterk te remmen (4A). Dit eiwit (PGP genaamd) werd vervolgens gezuiverd (4B) en gekarakterizeerd. Uit de aminozuursamenstelling en het feit dat het $\mathrm{N}$-terminale aminozuur geblokkeerd is, hebben we geconcludeerd dat PGP een specifiek Gla-eiwit is en géén afbraakprodukt van een bekend Gla-eiwit. De plaats waar PGP wordt gesynthetiseerd, is niet bekend. Het is mogelijk dat PGP 
gevormd wordt door het reeds eerder genoemde vitamin $\mathrm{K}$-afhankelijk carboxylase in de vaatwand. Een andere mogelijkheid is dat het eiwit elders gesynthetiseerd wordt en vervolgens uit de bloedcirculatie aan de verkalkte delen van de vaatwand geadsorbeerd wordt. Echter in beide gevallen kunnen we de aanwezigheid van PGP in plasma verwachten. Er werd een ELISA voor PGP ontwikkeld (4C). Hiermee werd aangetoond dat PGP vóórkomt in plasma en serum van gezonde vrijwilligers $(0.5-1.5 \mathrm{mg} / \mathrm{L})$. Tevens werden de plasma-PGP spiegels in 37 atherosclerotische patiënten gemeten en bleek dat het gemiddeld PGP-gehalte van deze groep sterk verlaagd was (minder dan $10 \%$ van normaal). Deze resultaten lijken veelbelovend en rechtvaardigen verder onderzoek. In de toekomst willen we aan de volgende punten aandacht schenken: 1) een zorgvuldige analyse van risikofactoren en plasma-PGP spiegels van patiënten opgenomen voor coronaire bypass chirurgie 2) een continuering van de screening van patiënten met een klinisch manifest ersntige vorm van atherosclerose, evt. gegroepeerd naar de aard van de onderliggende ziekte (homocystinurie, hypercholsteremie, diabetes mellitus) Het is duidelijk, dat de PGP-assay van groter klinisch belang kan worden als de test gebruikt kan worden om atherosclerose in een vroeg stadium van de ziekte te detecteren. Alvorens een antwoord op deze vraag te kunnen geven, moet het PGPgehalte van gezonde personen behorend tot een hoog risico groep voor coronaire hartziekten (roken, hoge bloeddruk, hoge serum-cholesterospiegels, erfelijke aandoeningen) bekend zijn. Een eerste aanzet hiertoe wordt in hoofdstuk $4 \mathrm{c}$ beschreven, waarin de plasma-PGP spiegels van 51 zware rokers bepaald werden. Het merendeel van de onderzochte personen hadden een duidelijk verlaagd plasma-PGP gehalte (10x beneden normaal). Hoewel deze bevindingen zeer suggestief zijn, moet voorzichtigheid betracht worden bij de interpretatie van de resultaten. In het beginstadium van het proces van atherosclerose zouden preventieve en therapeutische maatregelen een maximaal effekt kunnen hebben. In dit proefschrift hebben we een aantal hulpmiddelen voor deze studies beschreven, echter hun toepassing op grote schaal dient afgewacht te worden. 


\section{DANKWOORD}

Het tot stand komen van een proefschrift is niet de verdienste van één persoon, maar is het resultaat van een samenwerking tussen vele mensen. Een groot aantal mensen ben ik dan ook dank verschuldigd. In de eerste plaats mijn moeder, die mij de gelegenheid heeft geboden om te studeren. $\mathrm{Zij}$ heeft mij voortdurend gestimuleerd en mijn studie met grote belangstelling gevolgd.

Kees Vermeer, jouw optimisme, enthousiasme en vermogen om te relativeren hebben mij uit onderzoeksdalen gehaald waarin ik was terecht gekomen. Beste Kees, jouw hulp bij het schrijven is onmisbaar geweest. Nooit zal ik je middagbezoekjes aan het lab vergeten.

Berry Soute, jouw aanwezigheid op het lab is van wezenlijk belang geweest voor het tot stand komen van dit boekje. Beste Berry, je was altijd bereid om anderen te helpen.

Magda Ulrich, Peet van de Loo, Marjo Knapen, Ron Budé en Birgit Gijsbers, bedankt voor de gezellige samenwerking op het lab. Ik heb nooit tevergeefs een beroep op jullie gedaan om te assisteren bij het strippen van de aorta's.

Mariet Molenaar en Trees Camphuisen, jullie waren altijd bereid een briefje te typen of een declaratie op het laatste moment in te vullen. Beste Mariet, bedankt voor het typen van dit proefschrift. De komst van een nieuwe computer veroorzaakte onverwachts enkele problemen. Toch bleef je onder deze 'hectische omstandigheden' prima werk afleveren.

Karly Hamulyák wil ik bedanken voor zijn bijdrage aan de klinische delen van dit proefschrift.

Prof. Hemker, die het onderzoek steeds op afstand gevolgd heeft, dank ik voor het vertrouwen waarmee hij bereid was als promotor op te treden.

Dank ben ik ook verschuldigd aan de heren Flos en Swijen van de afdeling Pathologie-Anatomie van het St. Maartensgasthuis in Venlo, voor het verzamelen en beschikbaar stellen van de aorta's.

Prof. Dr. F.T. Bosman, Prof. Dr. P.J. Brombacher, Dr. E.J.P. Brommer (Gaubius Instituut TNO Leiden), Prof. Dr. F. ten Hoor en Dr. H.H.W. Thijssen ben ik erkentelijk voor de beoordeling van mijn proefschrift.

Dank ook aan alle overige, niet met name genoemde medewerker(sters) van de vakgroep Biochemie voor de prettige sfeer waarin ik heb mogen werken in Maastricht. Promoveren is geen feest, omdat het tevens een afscheid inhoudt. Ik zal met veel plezier aan de afgelopen tijd terug blijven denken.

Tenslotte wil ik jou, lieve Lucienne bedanken voor je steun, geduld en medeleven. Samen gaan we er iets moois van maken! 


\section{CURRICULUM VITAE}

De schrijver van dit proefschrift werd geboren te Maastricht op 31 mei 1960. Na het behalen van het diploma Gymnasium-B aan het Jeanne d'Arc Lyceum te Maastricht, werd in september 1978 aangevangen met de studie Biologie (specialisatie richting Medische Biologie) aan de Rijksuniversiteit van Utrecht. In september 1981 werd het kandidaatsexamen afgelegd en in september 1984 het doctoraalexamen met als hoofdvakken Haematologie (Dr. J.W.N. Akkerman) en Immunologie (Dr. H. Snippe) en als bijvak vergelijkende Endocrinologie (Prof. Dr. J.H.H. Thijssen). Van december 1984 tot en met november 1987 was hij als wetenschappelijk assistent in dienst van HGO-TNO werkzaam bij de vakgroep Biochemie van de Rijksuniversiteit Limburg te Maastricht. Van december 1987 tot en met juni 1988 was hij als toegevoegd onderzoeker verbonden aan de Rijksuniversiteit Limburg. Gedurende deze periode werd onder leiding van Dr. C. Vermeer het onderzoek verricht dat tot dit proefschrift heeft geleid. Van juli 1988 tot en met mei 1989 is hij als toegevoegd onderzoeker (part-time) verbonden aan de Rijksuniversiteit Limburg. 